$7-1-2000$

\title{
Harmonic Convergence? Constitutional Criminal Procedure in an International Context
}

Diane Marie Amann

University of Georgia School of Law, amann@uga.edu

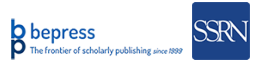

\section{Repository Citation}

Diane Marie Amann, Harmonic Convergence? Constitutional Criminal Procedure in an International Context (2000),

Available at: https://digitalcommons.law.uga.edu/fac_artchop/636

This Article is brought to you for free and open access by the Faculty Scholarship at Digital Commons @ University of Georgia School of Law. It has been accepted for inclusion in Scholarly Works by an authorized administrator of Digital Commons @ University of Georgia School of Law. Please share how you have benefited from this access For more information, please contact tstriepe@uga.edu. 


\title{
Harmonic Convergence? \\ Constitutional Criminal Procedure in an International Context
}

\author{
DIANE MARIE AMANN*
}

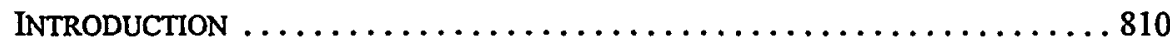

I. KEYNOTE: A MODEL OF CONSTITUTIONAL CRIMINAL PROCEDURE $\ldots \ldots \ldots 811$

II. CONCORDANCE: MOVEMENTS TOWARD A SHARED

CONSTITUTIONAL CRIMINAL PROCEDURE $\ldots \ldots \ldots \ldots \ldots \ldots \ldots \ldots . \ldots . \ldots . \ldots$

A. First Movements: Post-Revolutionary Reforms ........... 816

B. London Charter: An International Code of Criminal Procedure ..... 818

C. After Nürnberg: Cross-Border Crime and the Rights

of the Accused .................................... 820

1. Increased Global Crime and Law-Enforcement

Cooperation $\ldots \ldots \ldots \ldots \ldots \ldots \ldots \ldots \ldots \ldots \ldots \ldots \ldots . \ldots \ldots$

2. Protection of the Individual in International Law .......... 823

D. European Integration at the Vanguard of Convergence . . . . . . 825

1. European Court of Human Rights $\ldots \ldots \ldots \ldots \ldots \ldots \ldots \ldots \ldots$

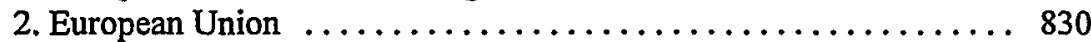

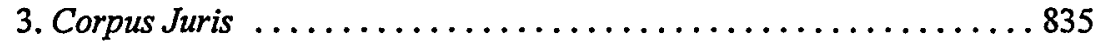

E. Toward Truly International Enforcement ............... . 839

1. Influence of Nongovernmental Organizations $\ldots \ldots \ldots \ldots \ldots . \ldots 839$

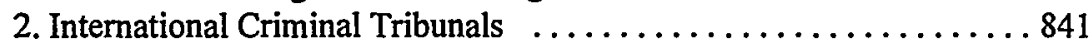

3. Proposed International Criminal Court $\ldots \ldots \ldots \ldots \ldots \ldots . \ldots . \ldots 44$

III. NOTES OF DISCORD: RESISTANCE TO A GLOBAL

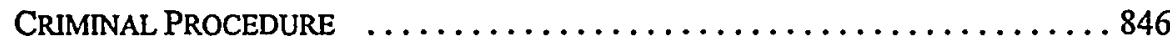

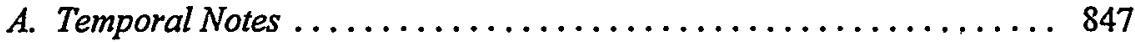

1. Crime ................................... 847

2. Lack of Resources ........................... 848

3. Uneasy Compromises $\ldots \ldots \ldots \ldots \ldots \ldots \ldots \ldots \ldots \ldots \ldots \ldots$

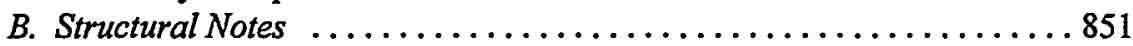

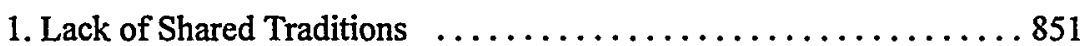

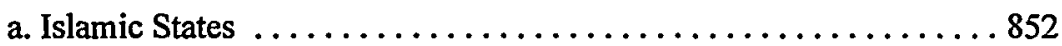

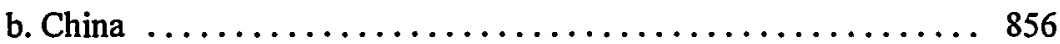

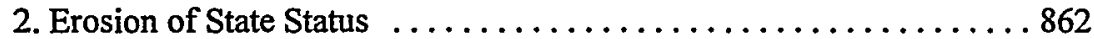

a. Proposed International Criminal Court $\ldots \ldots \ldots \ldots \ldots \ldots \ldots 62$

b. United States ................................ . 864

IV. TOWARD HARMONY? PROSPECTS FOR A SHARED,

CONSTITUTIONAL CRIMINAL PROCEDURE $\ldots \ldots \ldots \ldots \ldots \ldots \ldots . \ldots . \ldots 89$

* Acting Professor of Law, University of California, Davis, School of Law. I wish to thank Peter and Tiernan O'Neill, Ronald J. Allen, M. Cherif Bassiouni, Craig M. Bradley, Roger S. Clark, Sophie Cohen, Mireille Delmas-Marty, Holly Doremus, Kenneth S. Gallant, Frank Hoepfel, Thomas W. Joo, Hanno Kaiser, Albrecht Weber, Edward M. Wise, and Richard C. Wydick, as well as my research assistants, Cynthia R.L. Fairweather and Vivian Rhoe. A shorter version of this Article was presented in July 1999 at the Vth World Congress of the International Association of Constitutional Law in Rotterdam. 


\section{INTRODUCTION}

In Cambodia, a defender challenges a government witness by means of crossexamination, a procedure new to that state's courts. Meanwhile, the proper scope of such confrontation spurs argument before a tribunal at The Hague. In Rwanda, an attorney stands beside a defendant who, not long before, would have had no hope of representation. A court in Strasbourg scrutinizes the United Kingdom's use of compelled statements against a defendant, as Justices in the United States decline to apply an international concept of degrading treatment. Chinese defendants, traditionally considered offenders from the time of arrest, now enjoy a presumption of innocence. These examples point to an important global trend: the emergence, in national, regional, and international courts, in common law, civil law, and mixed systems, of a shared, a constitutional, criminal procedure.

Traditionally, how a state chose to fight crime was an internal matter. States developed their own methods to investigate crimes, to capture and try suspects, and to punish criminals. That changed in the last half-century. Crime became global, spurring law enforcement officers in individual states to join together in an international attack on crime. At the same time, a certain model, by which an individual's fundamental rights may outweigh a state's assertion of might, began to predominate. International norms respecting the treatment of accused individuals emerged, and states eager to entrench membership in the world political and economic community began to adopt them. Thus has the administration of criminal justice started to converge. ${ }^{1}$ Some accounts suggest a harmonic convergence, an eventual combination of various strains into a unified body of law. ${ }^{2}$

This Article explores whether such a convergence is possible. Part I posits, as a keynote around which harmony may develop, the model of constitutional criminal procedure built in the United States in the first part of the twentieth century. The model's core is the belief that the state must treat accused individuals equally, with due respect for their liberty; that is, to use the term preferred by the U.S. Supreme Court, with fundamental faimess. Part II traces global movements toward this kind of model. The process began at the time of the French Revolution and continued at the Nürnberg trials. It accelerated as the belief that an accused has certain rights won international acceptance, and as mounting crime prompted greater international law enforcement cooperation. Convergence has moved most rapidly in Europe as a part of that region's economic and political integration. International enforcement efforts

1. See, e.g., Craig M. Bradley, The Emerging International Consensus as to Criminal Procedure Rules, 14 MiCH. J. INT'L L. 171 (1993); Craig M. Bradley, The Convergence of the Continental and the Common Law Model of Criminal Procedure, 7 CRIM. L.F. 471 (1996) (reviewing Criminal Justice IN EUROPE: A COMPARATIVE StudY (Phil Fennell et al. eds., 1995)) [hereinafter Bradley, Convergence].

2. See Mireille Delmas-Marty, Toward a European Model of the Criminal Trial, in THE CRIMINAL PROCESS AND HUMAN RIGHTS 191, 195 (Mireille Delmas-Marty ed., 1995)(stating that in Europe, "a desirable, possible raproachment" between the common law and civil law procedure may have begun). The term "harmonic convergence" gained currency in a different context a decade ago, when thousands across the globe celebrated a unique astronomical alignment that they maintained would herald a New Age of spirituality. See Jonathan Weisman, New Age Believers Greet a New Day, L.A. TMms, Aug. 17, 1987, at 1. 
have grown, most recently in the 1998 Rome Statute of the proposed International Criminal Court. Part III sounds notes of discord. It demonstrates that in a number of countries-China, the Islamic states, France, and the United States-adherence to sovereignty and national tradition may prevent a full embrace of a global standard. Part IV examines implications of these global phenomena. Forces such as global crime and desires to participate in the world political and economic community will continue to motivate consensus. Still, some states will continue to resist out of perceived national interests. Because of these competing strains, the Article concludes, external pressures alone will not bring harmony. Rather, there must be acceptance of a shared norm, of a body of internationally recognized rights, as a fundamental component of civil society. Even if both are present, however, states will reject components of convergence that they believe threaten their security or position within the world community.

\section{KEYNOTE: A MODEL OF CONSTITUTIONAL CRIMINAL PROCEDURE}

The tenet that the individual enjoys natural or inalienable rights-rights that a state may not infringe- has a long history. It appeared in the writings of medieval natural law and Enlightenment philosophers throughout Europe. ${ }^{3}$ It fueled struggles against tyranny in England, on the European continent, and in the colonies. ${ }^{4}$ The concept of individual rights attained a new status at the founding of the United States of America. In 1789 the "People" of the new country adopted a written Constitution," which dispersed power among the legislative, the executive, and the judicial branches, each of which was to check the other. ${ }^{6}$ Power also was to be shared between the federal government and the governments of the constituent states. ${ }^{7}$

3. See P.K. Menon, The International Personality of Individuals in International Law: A Broadening of the Traditional Doctrine, 1 J. TRANSNAT'L L. \& POL'Y 151, 154-55 (1992); Onuma Yasuaki, Between Natural Rights of Man and Fundamental Rights of States, in ENLIGHTENMENT, RIGHTS AND REVOLUTION 134, 135-40 (Neil MacCormick \& Zenon Bankowski eds., 1989).

4. See, e.g., Diane Marie Amann, A Whipsaw Cuts Both Ways: The Privilege Against SelfIncrimination in an International Context, 45 UCLAL. REV. 1201, 1233-34(1998)(discussing such origins of the privilege against self-incrimination).

5. By proclaiming that "[w]e the People ... do ordain and establish this Constitution," U.S. CONST. preamble, the document endorsed social contract theories holding that civil societies formed when free individuals chose to join together for common purposes. See, e.g., ThOMAS HoBBES, LEVIATHAN ch. 17, at 223 (C.B. Macpherson ed., 1968) (1651) (positing that men "who naturally love Liberty" allow themselves to be restrained by the laws of "Common-wealths" in order to escape "that miserable condition of Warre"); JoHN LOCKE, TWO TREATISES OF GOVERNMENT 367 (Peter Laslett ed., Cambridge Univ. Press 1963)(1690) (stating that political society exists only "where every one of the Members hath quitted this natural Power, resign'd it up into the hands of the Community"); 1JEAN-JACQUES ROUSSEAU, The Social Contract, in THE SOCIAL CONTRACT AND DISCOURSES 163, 173-75 (G.D.H. Cole trans., Everyman's Libr. ed. 1973) (1762) (explaining "social compact" theory).

6. U.S. CONST. arts. I-III.

7. See id. amend. X (stating that powers neither delegated to the federal government nor prohibited to the states reside with the states or the people). 
This new Constitution contained some restraints on the prosecution and punishment of individuals. No conviction for treason, for example, was permitted unless there were two corroborating witnesses, and the writ of habeas corpus could not be suspended. ${ }^{8}$ But critics argued that the Constitution was incomplete because it failed to articulate the full scope of an individual's rights. In response, the new United States soon adopted a Bill of Rights, ten short amendments that restricted governmental action against individuals. Reflecting the secular philosophy that had arisen in the last century, ${ }^{9}$ the Bill of Rights assured free exercise of religion and forbade establishment of a state church. ${ }^{10}$ To promote individual autonomy, it guaranteed rights to freedom of expression and against unreasonable searches and seizures. It assured criminal defendants the rights not to testify against themselves, to have assistance of counsel, and to be tried by an impartial jury. "

In contrast with the proclamation of individual rights in the 1776 Declaration of Independence, which generally is considered aspirational, the enumeration in the 1791 Bill of Rights was to be enforceable. Little enforcement occurred in the early history of the United States, however, largely because the U.S. Supreme Court held that the Bill of Rights constrained only the federal and not the state governments. ${ }^{12}$ The Court adhered to a doctrine of dual sovereignty, which accorded states maximal freedom to operate in areas not ceded in the Constitution itself. ${ }^{13}$ Among those areas was the administration of criminal justice. ${ }^{14}$

The dual sovereignty doctrine eroded as a result of decisions interpreting the Fourteenth Amendment, which provides in part that "[n]o State shall ... deprive any person of life, liberty, or property, without due process of law."15 Litigation, sometimes supported by civil liberties and other organizations, drew national

8. See id. art. I, § 9; id. art. III, §3.

9. See M. Cherif Bassiouni, Sources of Islamic Law, and the Protection of Human Rights in the Islamic Criminal Justice System, in THE ISLAMIC CRIMINAL JUSTICE SYSTEM 3, 33 (M. Cherif Bassiouni ed., 1982) (pointing to 1648 Treaty of Westphalia as source of Western secularism); Kent Benedict Gravelle, Islamic Law in Sudan: A Comparative Analysis, 5 ILSA J. INT'L \& COMP. L. 1, 1 (1998) ("In a Western country such as the United States, government and law are separated from the Christian religion, although many of our most basic laws are drawn from the Bible.").

10. See U.S. CONST. amend. I.

11. See id. amends. V, VI.

12. This doctrine was first enunciated in Barron v. Mayor of Baltimore, 32 U.S. (7 Pet.) 243 (1833).

13. See Amann, supra note 4, at 1211-15 (discussing dual sovereignty doctrine).

14. See, e.g., Knapp v. Schweitzer, 357 U.S. 371,375 (1958) (stating that the "bulk of authority to legislate on what may be compendiously described as criminal justice, which in other nations belongs to the central government, is under our system the responsibility of the individual States").

15. U.S. CONST. amend. XIV, $\S 1$. The Fifth Amendment to the Constitution contains a parallel requirement for the federal government. The Fifth Amendment's Due Process Clause has been held to enjoin the federal government to guarantee equal protection of the laws, just as states must do pursuant to the Equal Protection Clause of the Fourteenth Amendment. See Bolling v. Sharpe, 347 U.S. 497 (1954). For a discussion of the process by which the dual sovereignty doctrine ended, see Duncan v. Louisiana, 391 U.S. 145, 147-58 (1968). 
attention to states' abuses of defendants. ${ }^{16}$ Members of the U.S. Supreme Court further expressed concern that greater cooperation between federal and state officers, prompted by increasing cross-border crime, threatened the rights of the accused. ${ }^{17} \mathrm{In}$ a series of decisions spanning the twentieth century, the Court held that the Due Process Clause required the states to obey provisions in the Bill of Rights that served "fundamental faimess,"18 a concept variously amplified as entailing principles of liberty and justice that are "at the base of all our civil and political institutions""; "implicit in the concept of ordered liberty... enshrined in the history and the basic constitutional documents of English-speaking people"';2 "part of the AngloAmerican legal heritage",21 and "essential to a fair trial.""22 The Court declared virtually all the rights contained in the Bill of Rights to be fundamental, and thus applicable throughout the United States. Defendants, whether in state or federal court, were entitled to appointment of counsel, ${ }^{23}$ to a privilege against self-incrimination, ${ }^{24}$ to be free from illegal searches, ${ }^{25}$ and to a public trial before a jury of their peers. ${ }^{26}$

16. See Dan M. Kahan \& Tracey L. Meares, The Coming Crisis of Criminal Procedure, 86 GEO. L.J. 1153, 1156 (1998) (stating that concerns about "institutionalized racism" gave rise to modern doctrine of criminal procedure); Carol S. Steiker, Second Thoughts About First Principles, 107 HARV. L. REv. 820, 838, 843-44 (1994) (making similar observation); see also Stephan Landsman, History's Stories, 93 Mich. L. REV. 1739, 1744 (1995) (reviewing JAMES GOODMAN, STORIES OF SCOTTSBORO (1994) (discussing roles that the Communist Party, the National Association for the Advancement of Colored People, and the American Civil Liberties Union played in litigation of two U.S. Supreme Court cases reversing convictions of young African-American defendants charged with rape of two white women in 1931 near Scottsboro, Alabama)).

17. See, e.g., Knapp, 357 U.S. at 385 (Black, J., dissenting) (complaining that, as a result of cooperation between state and federal officers, individuals could be "whipsawed" into sacrificing rights in one or both jurisdictions); cf. Amann, supra note 4, at 1218-20 (explaining interrelation between growing law enforcement cooperation and individual rights).

18. See, e.g., Duncan, 391 U.S. at 148-50; id. at 172-73, 177-92 (Harlan, J., dissenting); Irvine v. California, 347 U.S. 128, 148 (1954) ("[W] hen a conviction is secured by methods which offend elementary standards of justice, the victim of such methods may invoke the protection of the Fourteenth Amendment because that Amendment guarantees him a trial fundamentally fair in the sense in which that idea is incorporated in due process.").

19. Powell v. Alabama, 287 U.S. 45, 67 (1932) (quoting Hebert v. Louisiana, 272 U.S. 312, 316 (1926)); accord In re Oliver, 333 U.S. 257, 273 (1948) (describing due process as guaranteeing rights "basic in our system of jurisprudence").

20. Ingraham v. Wright, 430 U.S. 651, $673 \mathrm{n} .42$ (1976) (omission in original) (quoting Wolf v. Colorado, 338 U.S. 25, 27-28 (1949)).

21. Sniadach v. Family Fin. Corp., 395 U.S. 337, 343 (1969) (Harlan, J., concurring).

22. Gideon v. Wainwright, 372 U.S. 335, 344 (1963) (quoting Betts v. Brady, 316 U.S. $455,471(1942))$.

23. See id. at 335.

24. See Malloy v. Hogan, 378 U.S. 1 (1964).

25. See Wolf, 338 U.S. 25 (establishing right), overruled on other grounds by Mapp v. Ohio, 367 U.S. 643 (1961) (holding that remedy for impermissible search or seizure is exclusion of evidence).

26. See Duncan v. Louisiana, 391 U.S. 145 (1968) (jury trial); In re Oliver, 333 U.S. 257 (1948) (public trial). 
A government that denied those rights faced stiff sanctions, ranging from exclusion of evidence to reversal of conviction.

Out of this case law, decided by a Court that took seriously its constitutional role as a "bulwark" of liberty, ${ }^{27}$ a new model of criminal procedure emerged. It was derived not from any precise text, but from the Court's interpretation of the broad principles on which the United States was founded. Through this model the Court endeavored to serve both individual autonomy and public order, in a manner that is just and equal; that is, to use the Court's term, "fundamentally fair." ${ }^{28}$ The model has come to be called constitutional criminal procedure. It is "constitutional" not because its rules appear in a constitution, though they may. ${ }^{29}$ Rather, it is "constitutional" in that it assumes that certain rights are part of the constitutive nature of civil society. ${ }^{30}$ Constitutional criminal procedure does not simply involve choices among techniques for investigating and adjudicating crimes; it is a substantive law that constrains police, prosecutors, and judges. ${ }^{31}$

27. Maeva Marcus, The Adoption of the Bill of Rights, 1 WM. \& MARY BILL RTS. J. 115, 119 (1992) (quoting 1789 speech of James Madison that declared that if a Bill of Rights is adopted, judges "will be an impenetrable bulwark against every assumption of power in the legislative or the executive"). This image was a favorite of two Framers of the Constitution, Alexander Hamilton and James Madison. See THE FEDERALIST No. 78, at 508 (Alexander Hamilton) (1st Modern Library ed. 1941); Marcus, supra, at 119; see also Amann, supra note 4, at 1289-90, nn.557-58.

28. See Ronald J. Allentet al., Constitutional Criminal Procedure at xxiv (3d ed. 1995) (describing "the study of constitutional criminal procedure . . . as an inquiry into this nation's ever-changing view of the demands of human autonomy as reflected by the formal relationship between government and citizen").

29. Indeed, in many countries, rules now considered part of constitutional criminal procedure may be found neither in constitutions nor judicial decisions, but in statutes. See, e.g., Manfred Pieck, The Accused's Privilege Against Self-Incrimination in the Civil Law, 11 AM. J.COMP. L. 585, 585-86 (1962) (noting that in France, Germany, and the Netherlands, the right of an accused to remain silent is guaranteed in criminal procedure statutes). In such countries, the process is referred to as the "constitutionalizing" of, rather than as "constitutional," criminal procedure. See E-mail from Professor Doctor Albrecht Weber to Author (Aug. 16, 1999) (on file with author) (discussing German term Konstitutionalisierung). Although that terminology is not unknown in the United States, see, for example, Mitchell v. United States, 526 U.S. 314, 342-43 (1999) (Thomas, J., dissenting), this Article opts for the more common, less cumbersome, English language term.

30. See Wolf, 338 U.S. at 27 ("Due process of law thus conveys neither formal nor fixed nor narrow requirements. It is the compendious expression for all those rights which the courts must enforce because they are basic to our free society."); cf. Richard Bellamy, Introduction: Constitutionalism, Democracy and Sovereignty, in CONSTITUTIONALISM, DEMOCRACY AND SOVEREIGNTY: AMERICAN AND EUROPEAN PERSPECTIVES 1 (Richard Bellamy ed., 1996) (stating that constitutionalism reflects a "desire to subject the exercise of state power to certain normative limits").

31. See, e.g., Kahan \& Meares, supra note 16, at 1155 (among the effects of doctrines comprising "contemporary criminal procedure" is that "they constrain, both in substance and in form, the authority of the police to maintain order"); Carol S. Steiker, Counter-Revolution in Constitutional Criminal Procedure? Two Audiences, Two Answers, 94 MrCH.L. REv. 2466, 2470 (1996) ("[A]s any teacher of both substantive and procedural criminal law knows, constitutional criminal procedure is a species of substantive criminal law for cops."); $c f$. 
At times this model of constitutional criminal procedure is treated as if it were unique to the United States. ${ }^{32}$ In fact, however, it is a keynote around which global movements toward harmony may play out.

\section{CONCORDANCE: MOVEMENTS TOWARD A SHARED CONSTITUTIONAL CRIMINAL PROCEDURE}

How might harmonic convergence be achieved? What might prod divergent systems to merge into a body of law based on a model of constitutional criminal procedure? There is no one answer to these questions, no straight path to harmony ${ }^{33}$ In the United States, numerous factors contributed to the development of constitutional criminal procedure: a recognition that liberty, equality, and fairness were bedrock principles of civil society; a willingness on the part of the Supreme Court, sometimes urged by special interest groups, to interpret those principles to guarantee certain rights to accused individuals; and a concern that increased interaction between federal and state law enforcement officers threatened those rights. ${ }^{34}$ Similarly, in the international arena, the elements that may spur convergence are as varied and complex as global society itself.

Scholarship on international law and international relations offers ways to identify and explore the interplay of such elements. In a recent address, Professor Harold Hongju Koh listed a number of theories on why states come to obey international legal norms. "Realist" scholars, he explained, maintain that a state obeys simply because it is forced to do so by other states or by international bodies. "Rationalists" hold that a state chooses to obey based on a reasoned decision that obedience serves its self-interest. ${ }^{37}$ "Liberal Kantians" assume that states obey out of "a sense of moral obligation derived from considerations of fairness, democracy, and legitimacy that are embedded in their 'liberal,' domestic legal structures,"38 while "communitarian Grotians" focus on "the commonality of values within 'international society': a

Malinski v. New York, 324 U.S. 401, 414 (1945) (Frankfurter, J., concurring) ("The history of American freedom is, in no small measure, the history of procedure.").

32. See supra text accompanying notes 20-21 (indicating Court's linkage of due process to ideals of "English-speaking peoples" or "Anglo-American" tradition).

33. Cf. Mireille Delmas-Marty, Introduction to LIBERTÉS ET DROITS FONDAMENTAUX 9, 11 (Mireille Delmas-Marty \& Claude Lucas de Leyssac eds., 1996) (remarking, with regard to uncertainties of definition and application of fundamental rights, that " [it is not a matter of linear evolution, nor of unbroken progress]"') (citation omitted).

34. See supra text accompanying notes 15-31.

35. See Harold Hongju Koh, Bringing International Law Home, 35 Hous. L. REv. 623 (1998).

36. See id. at 634 (citing CHRIS BROWN, UNDERSTANDING INTERNATIONAL RELATIONS 9798 (1997)).

37. See id. (citing Anne-Marie Slaughter Burley, International Law and International Relations Theory: A Dual Agenda, 87 AM. J. INT'L L. 205, $218-19$ (1993) (discussing rationalist theories developed by Professor Robert $O$. Keohane)).

38. Id. at 635 (citing Thomas M. Franck, Community Based on Autonomy, 36 CoLUM. J. TRANSNAT'L L. 41, 41 (1997)). 
community that constructs national interests and identities." 39 Finally, "transnational legal process" theorists-among them Professor Koh-find incentives to obey in a state's myriad, repeated, global interactions.$^{40} \mathrm{For} \mathrm{Koh}$, these interactions include not only the state's "horizontal" relationships with other states through treaty-based regimes, ${ }^{41}$ but also its "vertical" relationships with domestic and foreign individuals, governmental officials, interest groups, courts, and other organizations. ${ }^{42}$ Obedience to international norms, he contends, results from "a complex combination" of all five theories. ${ }^{43}$ In short, Koh describes a dynamic that depends on the actions not only of states, but also of individuals and organizations.

This image of a dynamic global society well serves the instant inquiry. There is an ongoing movement toward convergence in criminal procedure, one with several sources. ${ }^{44}$ These include acknowledgment of certain fundamental principles of civil society, coercive and cooperative efforts among states, pressure from domestic and international human rights organizations, and establishment of international forums concerned with criminal justice matters. These elements often occur contemporaneously, sometimes pulling convergence in different directions. Indeed, as will be seen, some elements of harmony also sound notes of disharmony. First, however, an examination of the factors contributing to convergence is in order.

\section{A. First Movements: \\ Post-Revolutionary Reforms}

Two methods of criminal procedure long predominated in the West and, because of Western imperialism, in much of the world. ${ }^{45}$ One, the "inquisitorial" method, was part of the civil law system that prevailed in continental European states and their colonies. The second, the "accusatorial" method, was part of the common law system that held sway in England and in its present and former colonies, including the United States. In their purest form, the two methods differed considerably.

The accusatorial method, grounded in mistrust of the state, relied on an adversarial relationship between prosecution and defense lawyers as a prime means of arriving at justice. $^{46} \mathrm{~A}$ judge presided, but as a referee rather than as an active

39. Id. (emphasis omitted) (citing Benedict Kingsbury, A Grotian Tradition of Theory and Practice?: Grotius, Law, and Moral Skepticism in the Thought of Hedley Bull, 17 QUINNIPIAC L. REV. 3, 24 (1997)).

40. See id.

41. See id. (describing international legal process theory set forth in ABRAM CHAYES \& ANTONIA HANDLER CHAYES, THE NEW SOVEREIGNTY 1-3 (1995)).

42. See id. at 635-36; see also id. at 647-55 (setting out a taxonomy of these agents of interaction, including "transnational norm entrepreneurs," "transnational issue networks," and "interpretive communities and law-deciaring fora").

43. Id. at 633-34.

44. See supra notes 1-2.

45. See Matthew Lippman et al., Islamic Criminal Law and Procedure 3 (1988) (noting decline of Shari' $a$, Islamic law, in nineteenth century, as Islamic states adopted codes modeled on legal traditions of European colonizers).

46. See Bradley, Convergence, supra note 1, at 471-72; Nico Jörg et al., Are Inquisitorial and Adversarial Systems Converging?, in CRIMINAL JUSTICE IN EUROPE: A COMPARATIVE 
participant. ${ }^{47}$ The accusatorial method committed the verdict to lay jurors, yet constructed complex rules to prevent jurors from being misled by evidence that was probative but highly prejudicial. ${ }^{48}$ Defendants secured a privilege against giving selfincriminating testimony, in part on the theory that the state ought to secure conviction by its own labor, not by words from the defendant's mouth. ${ }^{49}$ Indeed, jurors were to convict only if the state proved guilt beyond a reasonable doubt. ${ }^{50}$

The inquisitorial method conferred immense power on the state. ${ }^{51}$ This method depended not on lay jurors but on a professional judge who performed investigations, levied accusations, and passed judgments. ${ }^{52}$ The judge directed a search for the truth with assistance from attorneys. ${ }^{53}$ Officials required defendants to testify, and often extracted confessions through torture. ${ }^{54}$ Evidence was freely admitted for consideration by the judge, who rendered a verdict based on conviction intime, or inner conviction. 55

STUDY 41, 42-43, 48 (Phil Fennell et. al eds., 1995); see also Mirjan Damaska, Evidentiary Barriers to Conviction and Two Models of Criminal Procedure: A Comparative Study, $121 \mathrm{U}$. PA. L. REV. 506, 565 (1973) (noting that "traditional Lockean liberal values, with distrust of the state and freedom from its restraint, were found to be in the ideological matrix of the adversary model").

47. See Otto Triffterer, Austrian/European Criminal Procedures Between Dogmatism and Pragmatism: The Evolution of Contemporary Experiences in Codification and Legislative Practices, in LES SYSTĖMES COMPARÉS DE JUSTICE PÉNALE: DE LA DIVERSITÉ AU RAPPROCHEMENT [COMPARATIVE CRIMTNAL JuSTICE SYSTEMS: From DIVERSITY to RAPPROCHEMENT] 467, 469 (1998) [hereinafter LES SYSTEMMS].

48. See MIRJAN R. DAMAŠKA, EVIDENCE LAW ADRIFT 12 (1997) (noting that "intense preliminary screening of evidence constitutes a salient trait of the Anglo-American fact-finding style").

49. See Miranda v. Arizona, 384 U.S. 436, 460 (1966) (setting forth this theory of the SelfIncrimination Clause of the Fifth Amendment, an "essential mainstay of our adversary system"). For an exhaustive historical review of the privilege in England and the United States, see the opinions in United States v. Gecas, 120 F.3d 1419 (11th Cir. 1997) (en banc), cert. denied, 524 U.S. 951 (1998).

50. See In re Winship, 397 U.S. 358, 361 (1970) (concluding that Due Process Clause allows conviction only if based on proof beyond a reasonable doubt, and observing that this standard is "virtually unanimous" in common law states).

51. This coincided with the French tradition that the law, as administered by the state, was the supreme guarantor against arbitrariness. See Delmas-Marty, supra note 33, at 9.

52. See Kurt Madlener, The Protection of Human Rights in the Criminal Procedure of the Federal Republic of Germany, in HUMAN RIGHTS IN CRMMNAL PROCEDURE 238, 238 (J.A. Andrews ed., 1982).

53. See Bradley, Convergence, supra note 1, at 471-72; Jörg et al., supra note 46, at 42-43; see also Damaska, supra note 46, at 565 (identifying "collectivistic values and benevolent paternalism ... as preconceptions" of inquisitorial method).

54. See Richard Vogler, Criminal Procedure in France, in COMPARATIVE CRIMINAL PROCEDURE 14, 24, 31-32 (John Hatchard et al. eds., 1996); see also Madlener, supra note 52, at 238.

55. See DAMAŠKA, supra note 48 , at 21 . In modern France, the doctrine of conviction intime still frees judges from evidentiary rules of exclusion, but requires verdicts based on rational inferences drawn from the evidence. See id. 
The systems began to converge as early as the eighteenth century. More precisely, continental European states, responding to French revolutionary ferment and to Enlightenment philosophers' critiques, infused the inquisitorial method with accusatorial techniques. ${ }^{56}$ For a time lay juries won prominence. ${ }^{57}$ The trial became a public contest between prosecution and defense..$^{58}$ The pretrial process, however, stayed largely secret and was governed by the juge d'instruction, or investigating judge, with police assistance. ${ }^{59}$ And though torture was prohibited, ${ }^{60}$ confessions remained a preferred form of evidence. ${ }^{61}$ Thus, even after post-revolutionary reforms, the methods still diverged.

\section{B. London Charter: An International Code of Criminal Procedure}

Accommodation of these two criminal procedure methods became critical in the mid-twentieth century. As World War II came to a close, the Allied Powers met in London to conclude a charter detailing the "constitution, jurisdiction and functions of the International Military Tribunal," which conducted the Nümberg trials of accused Nazi war criminals. ${ }^{62} \mathrm{~A}$ joint tribunal required a single procedure; however,

56. See Triffterer, supra note 47, at 468 (stating that throughout Europe, reformers "were struggling to realize demands of revolutionary ideas in order to establish guarantees for human liberty against the uncontrolled arbitrariness of absolute monarchs and state power"); Vogler, supra note 54, at 17 (commenting that the trial stage was "borrowed from the English and American models enthusiastically championed by Robespierre and the revolutionaries of 1792").

57. See Madlener, supra note 52, at 239. Although many European states later cut back on use of jurors, some states still employ mixed benches, in which lay persons deliberate with professional judges, in some types of cases. See id. See generally Rudolf B. Schlesinger, Comparative Criminal Procedure: A Plea for Utilizing Foreign Experience, 26 BUFF. L. REV. $361,363,366$ (1977) (discussing continental use of jurors).

58. See Madlener, supra note 52, at 239; Vogler, supra note 54, at 31.

59. See Madlener, supra note 52, at 238-39; Vogler, supra note 54, at 17. Although France and Spain, among others, still use the juge d'instruction, it has been abolished in Germany, Austria, and elsewhere in favor of an independent prosecutor charged with deciding whether to commence proceedings. See Madlener, supra note 52, at 240; Triffterer, supra note 47, at 469.

60. See Madlener, supra note 52, at 238; Trifferer, supra note 47, at 468 (noting that Austria abolished torture in 1776); Vogler, supra note 54, at 17 (stating that France abolished torture by 1786); Schlesinger, supra note 57, at 365, 377 (stating that modern European states condemn the use of physical force to extract confessions).

61. See Madlener, supra note 52, at 250 (stating that because inquisitorial procedure depended on accused's conféssion, "[s]elf-incrimination was, so to speak, built into that procedure"). The notion that a witness needed such a privilege ran counter to the assumption that, unlike the partisan police officer of the common law system, the inquiring judge would gather evidence dispassionately. Furthermore, whereas the common law system requires a defendant to speak under oath, at the risk of prosecution for perjury, see Schlesinger, supra note 57, at 377-80, in the civil law system it is considered "unacceptable," Madlener, supra note 52, at 251-52, to require a defendant to choose between self-incrimination and perjury.

62. See Agreement for the Prosecution and Punishment of the Major War Criminals of the 
the United States and England used the accusatorial method, while France and the Soviet Union applied the inquisitorial method. Commentators had underscored the differences between the methods, ${ }^{63}$ and a Nürnberg prosecutor recalled that the need to mesh the two was a nearly "intractable" problem. ${ }^{64}$

Article IV of the London Charter provided a bridge across this divide. ${ }^{65}$ In what amounted to an international code of criminal procedure, the charter included a number of accusatorial features, such as the rights to a detailed indictment, to conduct one's own defense or have assistance of counsel, and to present evidence and crossexamine prosecution witnesses. ${ }^{66}$ Indeed, its assignment of direct and crossexamination to the lawyers rather than to the court gave the trials a decidedly common law flavor. ${ }^{67}$ Yet aspects of the inquisitorial method remained. The defendant retained a right to explain himself at a preliminary hearing, and the cases were tried to a panel of four judges rather than to a lay jury.$^{68}$ Furthermore, the London Charter eschewed "technical rules of evidence" and allowed admission of all probative evidence, even if highly prejudicial. ${ }^{69}$ Uniting these disparate techniques was a common theme: the Allies titled Article IV "Fair Trial for Defendants," indicating that a concern for fairness to the accused should guide the proceedings. ${ }^{70}$

Nonetheless, by today's standards, the protections in the London Charter were minimal. Defendants were afforded no right to remain silent and no post-conviction

European Axis Powers and Charter of the International Military Tribunal, Aug. 8, 1945, 59 Stat. 1544, 82 U.N.T.S. 279 [hereinafter London Charter].

63. See, e.g., JOHN FISCHER WILLIAMS, CHAPTERS ON CURRENT INTERNATIONAL LAW AND THE LEAGUE OF NATIONS 252 (1929) (stating that criminal trials "are the matters in which the differences between Anglo-Saxon and continental law and practice are most profound").

64. TELFORd TAYLOR, THE ANATOMY OF THE NUREMBERG TRIALS 63 (1992).

65. See generally John F. Murphy, Norms of Criminal Procedure at the International Military Tribunal, in THE NUREMBERG TRIAL AND INTERNATIONAL LAW 61 (George Ginsburgs \& V.N. Kudriavtsev eds., 1990) (discussing the drafting and implementation of the London Charter).

66. See London Charter, supra note 62, art. 16, 59 Stat. at 1550, 82 U.N.T.S. at 294.

67. See Otto Pannenbecker, The Nuremberg War-Crimes Trial, 14 DEPAUL L. REv. 348, 349-50 (1964).

68. See London Charter, supra note 62 , arts. $2-4,16,59$ Stat. at $1546,1550,82$ U.N.T.S. at 284-86, 294.

69. See id. art. 19, 59 Stat. at 1551, 82 U.N.T.S. at 296 (further requiring that the Tribunal "shall adopt and apply to the greatest possible extent expeditious and nontechnical procedure, and shall admit any evidence which it deems to have probative value"); $c f$. FED. R. EVID. 403 (giving judge discretion to exclude evidence if probative value substantially outweighed by risk of undue prejudice).

70. London Charter, supra note 62, art. IV, 59 Stat. at 1550,82 U.N.T.S. at 294 . The charter establishing the post-World War II tribunal that tried Japanese war criminals also contained a section setting forth procedures "to insure [a] fair trial for the accused." International Military Tribunal for the Far East at Tokyo, April 26, 1946, § III, T.I.A.S. No. 1589,4 Bevans $20,23-24$. The section was shorter than the one in the London Charter, however. It included requirements regarding the indictment and language of proceedings; a right to counsel for accused; a right to conduct a defense, which encompassed a right to examine witnesses within "such reasonable restrictions as the Tribunal may determine"; and a procedure for asking the Tribunal to produce witnesses or documents. Id. 
right to appeal. ${ }^{71}$ Even contemporaries complained that, contrary to the promise of Article IV, the defendants did not receive a fair trial. ${ }^{72}$ Although the coercive aspect of trials organized by the victors to punish the vanquished doubtless played a role, other factors also contributed to this situation. This was, after all, an early attempt to combine civil law, common law, and military law systems. Furthermore, the trials took place in the mid-1940s, before even the U.S. Supreme Court had declared many procedures to be fundamental components of constitutional criminal procedure. ${ }^{73}$

\section{After Nürnberg: Cross-Border Crime and the Rights of the Accused}

As the post-World War II United States witnessed increased federal-state law enforcement cooperation and recognition of the rights of the accused grounded in fundamental fairness, ${ }^{74}$ the international community witnessed parallel developments. Thus, movements toward a global criminal procedure continued after the trials at Nürnberg ended.

\section{Increased Global Crime and Law-Enforcement Cooperation}

Global crime is on the rise. ${ }^{75}$ Genocide, war crimes, and torture are the unwelcome hallmarks of modern armed conflicts. At the same time, air travel and the Internet

71. See London Charter, supra note 62, arts. 16, 17(b), 59 Stat. at 1550, 82 U.N.T.S. at 294 (omitting right to silence from list of fair trial rights and giving the tribunal the power to interrogate defendants); id. art. 26,59 Stat. at 1552, 82 U.N.T.S. at 300 (barring review of convictions).

72. Critics included U.S. Supreme Court Justice William O. Douglas, Senator Robert Taft, and numerous scholars. See, e.g., U.S. DEP'TOF STATE, TRIAL OF JAPANESE WAR CRIMINALS, DOCUMENTS, PUBliCATION 2613, 45-62 (1946), reprinted in THE LaWs OF WAR: A COMPREHENSIVE COLlECTION OF PRIMARY DOCUMENTS ON INTERNATIONAL LAWS GOVERNING ARMED CONFLICT 334 (W. Michael Reisman \& Chris T. Antoniou eds., 1994) (quoting Douglas as saying, "II thought at the time and still think that the Nuremberg trials were unprincipled."'); JOHN F. KENNEDY, PROFILESIN COURAGE 236-44 (Commemorative ed. 1964) (discussing Taft's 1946 denunciation of the trials). The Tokyo trials, moreover, have been called "woefully" unfair to the accused. See, e.g., RICHARD H. MINEAR, VICTOR's Vengeance: THE TOKYo WAR CRIMES TRIAL 175-76 (1971); THE TOKYO WAR CRIMES TRIAL: AN INTERNATIONAL SYMPOSIUM (Chihiro Hosoya et al. eds., 1986).

73. See supra text accompanying notes 12-31.

74. See supra text accompanying notes $15-31$.

75. See, e.g., THE WhITE HouSE, INTERnational CRIME Control Strategy 15-25 (1998) (describing "international crime threat to U.S. interests" represented by, inter alia, transnational drug trafficking, smuggling of illegal goods and undocumented immigrants, money laundering, and pirating of intellectual property); MANUEL CASTELLS, END OF MLLENNIUM 166-205 (1998) (detailing growth of international criminal networks); RobertD. Kaplan, Hoods Against Democrats, ATLANTIC MONTHLY, Dec. 1998, at 32 (describing rise of organized crime in Bulgaria and its links to Russian organized crime); Judith Miller \& William J. Broad, Clinton Describes Terrorism Threat for 21st Century, N.Y. TIMES, Jan. 22, 1999, at A1 (reporting President Clinton's statements regarding fears of biological or chemical attacks). 
foster transnational crimes such as smuggling and money laundering. Criminals who endeavor to exterminate their own nationals, no less than those who seek to profit from cross-border trafficking, compel the global community to increase its crimefighting efforts. As shown by the efforts to bring to trial Yugoslav President Slobodan Miloševic ${ }^{76}$ former Chilean dictator Augusto Pinochet, ${ }^{77}$ and the Lockerbie bombing suspects, ${ }^{78}$ states now are willing to pursue, prosecute, and punish international criminals. ${ }^{79}$

The law enforcement reach of the United States extends particularly far, including more than a hundred posts and more than 1500 employees worldwide. ${ }^{80}$ Joint investigations, as well as U.S. agents' training of and consultation with other states' officers, have resulted in a number of prosecutions and seizures of contraband. ${ }^{81}$

76. See Prosecutor v. Milošević, Case No. IT-99-37-I, Indictment (May 22, 1999) (visited Mar. 30, 2000)<http://www.un.org/icty/indictment/english/mil-ii990524e.htm>; Roger Cohen, Warrants Served for Serbs' Leader and 4 Assistants, N.Y. TIMES, May 28, 1999, at A1.

77. In a landmark opinion, the English House of Lords ruled 6-1 that Pinochet was not immune from extradition to Spain for crimes committed after 1988, when English law first proscribed extraterritorial torture. See Regina v. Bartle (H.L. 1999), reprinted in 38 I.L.M. 581 (1999). The British government recently released Pinochet on the ground that he was not well enough to stand trial in Spain; nonetheless, a Chilean judge continues his efforts to prosecute Pinochet in Chile. See Clifford Krauss, Pinochet, at Home in Chile: A Real Nowhere Man, N.Y. TIMES, Mar. 5, 2000, § 1, at 12.

78. After years of negotiations, Libya surrendered for trial two of its nationals, suspects in the 1988 bombing of an airliner over Scotland. See Marlise Simons, 2 Libyan Suspects Handed to Court in Pan Am Bombing, N.Y. TMmes, Apr. 6, 1999, at A1. Scottish judges will preside at the trial, to be held at a former military base in the Netherlands. See id.

79. At one time the "intrusive" nature of criminal prosecution had prompted U.S. law enforcement agencies to invoke it "sparingly . . . and only upon strong justification." RESTATEMENT (THIRD) OF THE FOREIGN RELATIONS LAW OF THE UNITED STATES § 403 reporter's note 8 (1987) [hereinafter RESTATEMENT]. That changed in the last two decades, however, as the international community increased its investigation and prosecution of global crime. See, e.g., Scott Sultzer, Money Laundering: The Scope of the Problem and Attempts To Combat It, 63 TENN. L. REv. 143, 212-14 (1995); Christopher S. Wren, Long Arm of U.S. Law Gets Longer, N.Y. TIMES, July 7, 1996, § 4, at 4; see also United States v. Yousef, 927 F. Supp. 673, 681-82 (S.D.N.Y. 1996) (accepting U.S. argument that universality, as well as territoriality, principle justified prosecution for conspiring to bomb U.S. airliners operating overseas).

80. An unofficial U.S. State Department report in the mid-1990s found that U.S. law enforcement agencies employed 1649 people overseas. See David Johnston, Strength Is Seen in a U.S. Export: Law Enforcement, N.Y. TIMES, Apr. 17, 1995, at A1. Agents of the Federal Bureau of Investigation and the Drug Enforcement Administration, just two of more than a dozen U.S. agencies operating abroad, were stationed in 116 posts. See R. Jeffrey Smith \& Thomas W. Lippman, FBI Plans To Expand Overseas, WASH. PosT, Aug. 20, 1996, at A1 (noting FBI plans for 46 permanent offices abroad); see also ETHAN A. NADELMANN, COPS ACROSS BORDERS 3 (1993) (stating that, as of 1991, DEA agents were stationed in 70 foreign cities); Foreign Operations, Export Financing, and Related Programs Appropriations for Fiscal Year 1998, Hearings Before the Subcomm. of the Comm. on Appropriations, 105th Cong. 57-64 (1998) [hereinafter Freeh Statement] (statement of FBI Director, Louis J. Freeh) (listing other agencies active overseas).

81. See Freeh Statement, supra note 80, at 62-63; cf. Elizabeth Olson, Ex-Soviets Are Focus 
Many states have concluded treaties promising mutual assistance in the investigation of crime and in the return of fugitives and prisoners. ${ }^{82}$ International agencies such as the Vienna-based U.N. Centre for International Crime Prevention ${ }^{83}$ and the Parisbased Financial Action Task Force ${ }^{84}$ coordinate global policy. The International Criminal Police Organization, or Interpol, circulates information and helps track international fugitives. ${ }^{85} \mathrm{~A}$ similar European police force now operates. ${ }^{86}$

These bilateral and multinational cooperative efforts foster greater understanding, acceptance, and adoption of certain ways of administering criminal justice. Treaties, for example, routinely specify procedures for protection of requested fugitives or persons otherwise subjected to international law enforcement activities. ${ }^{87}$ International bodies admonish member states to adhere to certain norms for treating

of Inquiry by the Swiss, N.Y.TIMES, Dec. 20, 1998, § 1, at 19 (describing Swiss efforts to work with Russian and Ukrainian authorities to combat organized crime).

82. See generally WHITE HouSE, supra note 75 , at 39-46, 78 (setting as goal for fighting global crime greater cooperation through means such as mutual legal assistance treaties and extradition); Amann, supra note 4, at 1263-67 (discussing how international treaties further law enforcement cooperation).

83. See Centre for Int'l Crime Prevention, Introduction (last modified Jan. 24, 2000) $<$ http://www.uncjin.org/CICP/cicp.html> (describing cooperative activities). For a comprehensive discussion of U.N. efforts, see ROGER S. CLARK, THEUNITED NATIONS CRIME PREVENTION AND CRIMINAL JUSTICE PROGRAM (1994).

84. Seven major industrial states formed this task force in 1989 to study and issue recommendations on means to stop the flow of illegally laundered money. Twenty-six countries are members, including Hong Kong and Switzerland, considered money laundering centers. See Financial Action Task Force on Money Laundering, About FATF (visited Mar. 24, 2000) <http://www.oecd.fr/fatf/about.htm>.

85. See Amann, supra note 4, at 1267-68 (describing activities and criticism of Interpol); cf. Ronald K. Noble, A Neglected Anti-Terror Weapon, N.Y. TimES, Sept. 9, 1998, at A25 (calling, in wake of terrorist bombings of U.S. embassies in Africa, for strengthening of Interpol to increase ability to combat international terrorism and other crimes).

86. See Convention of 20 July 1995 Based on Article K.3 of the Treaty on European Union, on the Establishment of a European Police Office, Annex, 1996 O.J. (C299) 1 (entered into force Oct. 1, 1998); Charles Bremner, EU Police Force Finally Ready To Fight Crime, TIMES (London), Oct. 2, 1998, at 20.

87. See, e.g., Inter-American Convention on Serving Criminal Sentences Abroad, Jan. 10, 1995, art. IV(1), S. TREATY DOC. No. 104-35 (1996) (requiring members to inform sentenced nationals of another member state of treaty-based right to be transferred home for service of sentence); Council of Europe: Convention on Laundering, Search, Seizure and Confiscation of the Proceeds from Crime, Nov. 8, 1990, art. 18(4)(f), 30 I.L.M. 148, 156 (permitting a state to refuse another state's request for confiscation of property if confiscation order fails to give due regard to "minimum rights of defence"); U.N. Convention Against Illicit Traffic in Narcotic Drugs and Psychotropic Substances, Dec. 20, 1988, art. 6(6), 28 I.L.M. 493, 507 (allowing requested state to refuse to extradite if it believes compliance would discriminate against fugitive on basis of race, religion, nationality, or political opinions); Supplementary Extradition Treaty Between the Government of the United States of America and the Government of the United Kingdom of Great Britain and Northern Ireland, June 25, 1985, arts. 3-4, U.S.-U.K., as amended, T.I.A.S. No. 12050 (entered into force Dec. 23, 1986) (setting forth grounds for denying extradition request, including insufficiency of evidence, failure to permit fugitive to present evidence in U.S. court, and discriminatory basis for request). 
accused and convicted persons ${ }^{88}$-rights that won international acceptance even as cross-border crime and crime-fighting increased. ${ }^{89}$

\section{Protection of the Individual in International Law}

Out of what Professor Mireille Delmas-Marty has called "the shock of World War II" arose a renewed belief that individuals enjoy certain fundamental rights which a state may not infringe..$^{90}$ States demonstrated this commitment by explicit guarantees in new constitutions, ${ }^{91}$ and by judicial decisions making clear that the state must honor the individual's fundamental rights. ${ }^{92}$ Further recognition that international law protects not only the interests of nation-states, but also the rights of the individual, ${ }^{93}$

88. Among the many U.N. documents setting such standards, see generally CLARK, supra note 83, at 97-125, 147-79, are: Basic Principles for the Treatment of Prisoners, G.A. Res. 45/111, U.N. GAOR, 45th Sess., Supp. No. 49A, at 199, U.N. Doc. A/45/49 (1990) (prescribing minimum standards states ought to follow when incarcerating individuals); Guidelines on the Role of Prosecutors, Eighth U.N. Congress on the Prevention of Crime and the Treatment of Offenders, U.N. Doc. A/CONF.144/28/Rev.1 (1990) (report prepared by Secretariat) (imposing on prosecutors duty to ensure fair trial rights such as equality before the law, presumption of innocence, and public hearing before impartial judge); Standard Minimum Rules for the Administration of Juvenile Justice, G.A. Res. 40/33, U.N. GAOR, 40th Sess., Supp. No. 53, at 206, U.N. Doc. A/40/53 (1986) (guaranteeing fair trial type rights yet stressing rehabilitation as goal of juvenile law).

89. See M. Cherif Bassiouni, Human Rights in the Context of Criminal Justice: Identifying International Procedural Protections and Equivalent Protections in National Constitutions, 3 DUKE J. COMP. \& INT'L L. 235, 240 (1993) (observing that rise in both international and transnational crime has "broken through national sovereignty barriers," resulting in increased application, in national courts, of international standards of criminal justice); $c f$. Delmas-Marty, supra note 2, at 194 (describing human rights as "one of the by-products of modern criminal procedure").

90. Delmas-Marty, supra note 33, at 10 (discussing how Second World War experience transformed notions of state-individual relations in France and Germany).

91. See, e.g., BASIC LAW FOR THE FEDERAL REPUBLIC OF GERMANY arts. 1-19, reprinted in DAVID P. CURRIE, THE CONSTITUTIONOF THE FEDERAL REPUBLICOF GERMANY app. at 34351 (1994) (enumerating fundamental individual rights as first part of Germany's postwar Constitution). See Volkmar Götz, Minorities, Human Rights and Peace within the State, in STUDIES N GERMAN CONSTITUTIONALISM 71, 78 (Christian Starck ed., 1995) (linking central placement of human rights in the Basic Law to abuses during the Nazi regime).

92. See generally Margaret Raymond, Rejecting Totalitarianism: Translating the Guarantees of Constitutional Criminal Procedure, 76 N.C. L. REv. 1193 (1998) (demonstrating how perceived need to hold U.S. system as antithetical to Nazi and Stalinist totalitarianism prompted Supreme Court opinions guaranteeing individual rights). See also Jean Gicquel, $L$ 'applicabilité directe de la norme constitutionelle, in LIBERTÉS ET DROITS FONDAMENTAUX, supra note 33, at 237, 237-38 (stating that as a result of a 1971 decision of the French Conseil constitutionnel, the notion that the state is subject to law-a notion contrary to the original underpinnings of the inquisitorial method-" "has become . . . a reality in France").

93. See Amann, supra note 4, at 1245-51 (describing global trend toward recognition of individual rights). 
came in a progression of multilateral agreements. Common to each agreement was a stated commitment to fair and equal treatment of individuals and to protection of individual dignity. Thus the Charter of the United Nations underscored the importance of "fundamental," "equal" human rights and "the dignity and worth of the human person."

The Universal Declaration of Human Rights ${ }^{96}$ was the first instrument to couple this commitment with an enumeration of individual rights related to criminal justice. Included were: protection against arbitrary arrest, detention, or invasions of privacy; a presumption of innocence; and a promise of "full equality" at a fair, public trial, before a neutral arbiter, with "all the guarantees necessary" for the defense. ${ }^{97}$ Regional human rights conventions have catalogued such rights in greater detail. ${ }^{98}$

94. U.N. CHARTER pmbl.

95. See, e.g., Charter of the Organization of African Unity, May 25, 1963, 479 U.N.T.S. 39,70 (entered into force Sept. 13, 1963) (stating that "freedom, equality, justice and dignity are essential objectives"); Statute of the Council of Europe, May 5, 1949, 87 U.N.T.S. 103, 104 (entered into force Aug. 3, 1949) (citing "individual freedom, political liberty and the rule of law" as "principles which form the basis of all genuine democracy").

96. Universal Declaration of Human Rights, G.A. Res. 217 A (III), U.N. GAOR, 3d Sess., pt.1, at 71, U.N. Doc. A/810 (1948) [hereinafter UDHR].

97. Id. arts. 9-12. Similarly, the Geneva Conventions on the laws of war, concluded a year later, contained "a mini-code on the requirements of a fair trial." Roger S. Clark, Offenses of International Concern: Multilateral State Treaty Practice in the Forty Years Since Nuremberg, 57 NORDIC J. INT'L L. 49, 71 (1988).

98. See African Charter on Human and Peoples' Rights, June 27, 1981, arts. 3-7, reprinted in 21 I.L.M. 59 (reprinted as Banjul Charter on Human and Peoples' Rights) [hereinafter African Human Rights Charter]; American Convention on Human Rights, opened for signature Nov. 22, 1969, arts. 7-8, 11, 1144 U.N.T.S. 123, 147-48 (entered into force July 18, 1978) [hereinafter American Human Rights Convention]; Convention for the Protection of Human Rights and Fundamental Freedoms, opened for signature Nov. 4, 1950, arts. 5-8, 213 U.N.T.S. 222, 226-30 (entered into force Sept. 3, 1953) [hereinafter European Human Rights Convention].

With regard to criminal trials, all three conventions entitle the accused to a fair hearing. See African Human Rights Charter, supra, arts. 6, 7(1) (guaranteeing a right to be heard and forbidding deprivations of liberty without reason); American Human Rights Convention, supra, arts. 8(1), 8(5) (under heading "Right to a Fair Trial," requiring hearing "with due guarantees"); European Human Rights Convention, supra, art. 6(1). The accused further is entitled: to a presumption of innocence; to be heard without undue delay by a competent, neutral tribunal; and to a right to defense, including assistance of counsel. See African Human Rights Charter, supra, art. 7; American Human Rights Convention, supra, art. 8; European Human Rights Convention, supra, art. 6. The American and European Conventions also guarantee that the trial will be public, that the defendant will receive notice of charges, and that the defendant will be permitted to cross-examine adverse witnesses and compel the presence of favorable witnesses. See American Human Rights Convention, supra, art. 8; European Human Rights Convention, supra, art. 6 . The American Convention further provides that no one may be compelled to give self-incriminating testimony, that coerced confessions shall be excluded from evidence, and that a convicted defendant has a right to appeal. See American Human Rights Convention, supra, arts. 8(2)(g)-(h), 8(3); accord African Human Rights Charter, supra, art. 7(1)(a) (ensuring right to appeal). 
Joining these efforts was the International Covenant on Civil and Political Rights, ${ }^{99}$ often described as part of an International Bill of Rights. ${ }^{100}$ Like the regional instruments, the Covenant carefully detailed rights to personal liberty, dignity, and privacy. ${ }^{101}$ Its fair trial rights were most extensive, providing for, inter alia: an equal, fair, public, and speedy trial before a competent tribunal; a presumption of innocence; the rights to be informed of the charges, to have assistance of an interpreter, and to have adequate time and resources to prepare a defense; the assistance of counsel, including appointment of state-paid counsel if necessary; the rights to cross-examine adverse witnesses and to secure favorable witnesses; the right to silence; the right to an appeal; compensation for unjust convictions; and the right against double jeopardy. ${ }^{102}$ Ratified by nearly three-quarters of the members of the United Nations, the Covenant provides the basis for a set of shared expectations about how states ought to treat the accused. ${ }^{103}$ Thus it stands to become a central component of a new, global, constitutional criminal procedure. ${ }^{104}$

\section{European Integration at the Vanguard of Convergence}

Although the International Covenant on Civil and Political Rights, with its list of the rights of the accused, has the potential to lead the development of a global body of constitutional criminal procedure, its promise remains largely unrealized. No permanent international criminal court yet exists that might apply the ICCPR's provisions, and domestic laws in many states limit its applicability. ${ }^{105}$ For these

99. International Covenant on Civil and Political Rights, Dec. 16, 1966, 999 U.N.T.S. 171 (entered into force Mar. 23, 1976) [hereinafter ICCPR].

100. See, e.g., Louis Henkin, The International Bill of Rights: The Universal Declaration and the Covenants, in INTERNATIONAL ENFORCEMENT OF HUMAN RIGHTS 1, 1 (Rudolf Bernhardt \& John Anthony Jolowicz eds., 1985). The other parts are the UDHR, supra note 96, and the International Covenant on Economic, Social and Cultural Rights, Dec. 16, 1966, 993 U.N.T.S. 3 (entered into force Jan. 3, 1976). In 1992, the United States ratified the ICCPR; 144 of the U.N.'s 185 members are parties. See U.N. Treaty Collection (last modified Oct. 28, 1999) <http://www.un.org/Depts/Treaty/final/ts2/newfiles/part_boo/iv_boo/iv_4.html>; See also NEW ZEALAND MINISTRY OF FOREIGN AFFAIRS \& TRADE, UNITED NATIONS HANDBOOK 11 (1996). The United States has not ratified the Economic and Social Rights Covenant, which has 142 parties. See U.N. Treaty Collection (last modified Oct. 28, 1999)<http://www.un.org/ Depts/Treaty/final/ts2/newfiles/part_boo/iv_boo/iv_3.html>.

101. See ICCPR, supra note 99, arts. 9-10, 17.

102. See id. art. 14.

103. See M. CHERIF BASSIOUNI, INTERNATIONAL CRIMINAL LAW: ADRAFT INTERNATIONAL CRIMINAL CODE 1 (1980) ("As a consequence of these shared values and expectations, the world community has come to require of its participants a greater degree of conformity and compliance with certain minimum standards of behaviour for the attainment of its perceived goals of collective and personal security.").

104. See, e.g., Luigi Ferrajoli, Beyond Sovereignty and Citizenship: A Global Constitutionalism, in CONSTITUTIONALISM, DEMOCRACY AND SOVEREIGNTY:AMERICANAND EUROPEAN PERSPECTIVES, supra note 30, at 155 (describing U.N. Charter and subsequent human rights conventions as a "global constitution in embryo").

105. An optional protocol permits individuals to complain to the U.N. Human Rights 
reasons, it is not the Covenant, but rather the ongoing formation of a European Union, that stands at the vanguard of convergence. ${ }^{106}$ As this Article will show, opinions of the European Court of Human Rights enunciating rights of the accused have led the way. Promising to have an effect in the future is the political and economic integration taking place within the European Union. Of particular interest is Corpus Juris, a project aimed at developing a single means to investigate, prosecute, and punish financial crimes against the Union.

\section{European Court of Human Rights}

Efforts to bring European states closer together began as part of the post-World War II rebuilding of the continent. In 1949, ten states formed the Council of Europe in the hope of strengthening political ties among governments. ${ }^{107} \mathrm{~A}$ year later came the Council's premier achievement, the European Convention for the Protection of Human Rights and Fundamental Freedoms. ${ }^{108}$ Like its forebear, the Universal Declaration, the European Human Rights Convention stressed the new importance in international law of the rights of the individual. Unlike the Universal Declaration, however, the Convention offered concrete protection of those rights, via a judiciary that would hear individual complaints and issue sanctions against offending states. ${ }^{109}$

Committee that their rights under the ICCPR have been violated. See Optional Protocol to the International Covenant on Civil and Political Rights, art. 1, 999 U.N.T.S. 302 (1976) (entered into force Mar. 23, 1976). After review, the Committee "shall forward its views to the State Party concerned and to the individual." Id. art. 5. Ninety-five states are parties to this optional protocol; among those that have not joined are the United States and the United Kingdom. See U.N. Treaty Collection (last modified Oct. 28, 1999) <http://www.un.org/Depts/Treaty/final/ ts2/newfiles/part_boo/iv_boo/iv_5.html\#\$w823aPatr>.

106. Other regional courts may one day play a role in developing an international body of constitutional criminal procedure. The Inter-American Court of Human Rights only recently began issuing opinions enforcing the American Human Rights Convention, supra note 98 . See Thomas Buergenthal, The Normative and Institutional Evolution of International Human Rights, 19 HUM. RTS. Q. 703, 716 (1997). This charter is not ratified by the United States. See ENCYCLOPEDIA OF HUMAN RIGHTS 1679 (Edward Lawson ed., 2d ed. 1996). Meanwhile, the Organization of African Unity has opened for ratification a protocol to establish a court to enforce the African Human Rights Charter, supra note 98. See Hamid Boukrif, La Cour africaine des droits de l'homme et des peuples: Un Organe judiciaire au service des droits de l'homme et des peuples en Afrique, 10 AFR. J. INT'L \& COMP. L. 60 (1998) (analyzing protocol). Also of significance are commissions and committees charged with monitoring human rights abuses, although further consideration of such vehicles is beyond the scope of this Article. See, e.g., Rod Morgan, Another Angle on European Harmonisation: The Case of the European Committee for the Prevention of Torture, in THENEW EUROPEAN CRIMINOLOGY 156 (Vincenzo Ruggiero et al. eds., 1998).

107. The original members were Belgium, Denmark, France, Ireland, Italy, Luxembourg, the Netherlands, Norway, Sweden, and the United Kingdom. See The 41 Member States of the Council of Europe (last modified June 25, 1999) <http://www.coe.fr/eng/std/states.htm>.

108. European Human Rights Convention, supra note 98.

109. See, e.g., Rolv Ryssdall, Opinion: The Coming of Age of the European Convention on Human Rights, 1 EUR. HUM. RTS. L. REv. 18, 19, 28 (1996) (describing the Convention's 
Furthermore, given that both the common law and civil law systems were represented among its original members, the Convention marked an early step toward legal integration. ${ }^{110}$

The European Convention's fair trial provisions, contained largely in Article 6, are less extensive than those in the ICCPR. Nonetheless, vigorous litigation has produced a series of opinions interpreting the Convention to accord ample protection to criminal defendants. In 1989, the European Court of Human Rights held that the Netherlands had denied a defendant a fair and public hearing and unduly curtailed his right to examine witnesses, in violation of Article $6 .{ }^{111}$ In 1996, the court inferred a right to silence out of the Convention's fair trial guarantees, and thus held that the United Kingdom had breached the same article by convicting a defendant based on statements compelled from him during investigation. ${ }^{112}$ In an oft-cited opinion, the court warned the United Kingdom not to extradite a defendant to the United States on the ground that, if convicted and condemned to a prolonged wait for execution, the defendant might suffer inhuman treatment in violation of Article $3 .^{113}$

Several aspects of the court's rulings, beyond their precise holdings, deserve note. In order to interpret its own charter - the Convention that the court has described as "a constitutional instrument of European public order"114 _ the court relied on divers sources. These included its own decisions; ${ }^{115}$ opinions of other courts in Europe and

"supervisory machinery"). The Convention provided for a European Commission of Human Rights to review petitions and work for resolution of petitions from individuals and nongovernmental organizations. See European Human Rights Convention, supra note 98, arts. 19-37. The European Commission, as well as state parties, could refer matters to the European Court of Human Rights, which has enforceable sanction powers. See id. arts. 44-56. The Commission was abolished in 1998 in favor of a unitary, judicial system. See Peter Leuprecht, Innovations in the European System of Human Rights Protection: Is Enlargement Compatible with Reinforcement?, 8 TRANSNAT'L L. \& CONTEMP. PROBS. 313, 320 (1998).

110. Cf. Jörg et al., supra note 46, at 54-56 (describing Convention as force for convergence); Schlesinger, supra note 57, at 363-64 (stating that by following Convention, continental states had adopted "general standards of procedural fairness quite comparable to due process notions" in the United States).

111. See Kostovski v. Netherlands, 166 Eur. Ct. H.R. (ser. A) at 20-21 (1989).

112. See Saunders v. United Kingdom, 24 Eur. Ct. H.R. at 2044 (1996) (relying on European Human Rights Convention, supra note 98, arts. 6(1)-(2) (rights to fair, public hearing and to presumption of innocence)); see also Murray v. United Kingdom, 1 Eur. Ct. H.R. at 30, 57-58 (1996) (declaring the privilege not to give self-incriminating testimony and the right not to speak during an interrogation "generally recognised international standards of fair procedure," yet concluding that, on the facts before it, a Northern Ireland court did not violate these standards when it drew adverse inferences from a defendant's post-arrest silence).

113. See Soering v. United Kingdom, 161 Eur. Ct. H.R. (ser. A) at 34-44 (1989) (interpreting Article 3 of the European Human Rights Convention, which states, "No one shall be subjected to torture or to inhuman or degrading treatment or punishment."); see also infra text accompanying note 128 (discussing subsequent reliance on Soering).

114. Loizidou v. Turkey, 310 Eur. Ct. H.R. (ser. A) at 27 para. 75 (1995).

115. See, e.g., Saunders, 24 Eur. Ct. H.R. at 2044, para. 67. Saunders discussed Funke v. France, 256 Eur. Ct. H.R. (ser. A) at 26 (1993) (ruling that French courts, by ordering defendant to produce financial documents, deprived defendant of right to silence implicit in the guarantees of a fair trial in Article 6). 
beyond; ${ }^{116}$ international instruments; ${ }^{117}$ academic writings; $; 18$ and practices related to the accusatorial and the inquisitorial methods of criminal procedure. ${ }^{119}$ The court's deliberations have been aided by briefs not only from litigants, but also from human rights organizations. ${ }^{120}$ Moreover, in each case, the supranational Court of Human Rights imposed a sanction, for violation of a quasi-federal rule, upon a court that had followed its own state's law. ${ }^{121}$ Thus, through a process that bears resemblance to the development of a constitutional criminal procedure in the United States, ${ }^{122}$ the European court has established a rule of law that all forty-one states now subject to its jurisdiction must abide. ${ }^{123}$ Indeed, states not party to a case often enact laws

116. See, e.g., Saunders, 24 Eur. Ct. H.R. at 2101-02 (noting main opinion's citations to decisions from England, South Africa, and United States); id. at 2101-02 (Loucaides, J., concurring) (citing, inter alia, United States v. Bryan, 339 U.S. 323 (1950), and Twining v. New Jersey, 211 U.S. 78 (1908), to support majority's recognition of right against selfincrimination); Murray, 1 Eur. Ct. H.R. at 62-65 (Pettiti, J., joined by Valticos, J., partly dissenting, Walsh, J., joined by Makarczyk and Lōhmus, JJ., partly dissenting) (each citing Miranda v. Arizona, 384 U.S. 436 (1966), and Griffin v. California, 380 U.S. 609 (1965), to argue for a broader right to silence than majority supports).

117. See Saunders, 25 Eur. Ct. H.R. at 2063, para. 66 (noting reference to several human rights conventions and to national laws by amicus nongovernmental organization); Murray, 1 Eur. Ct. H.R. at 47, para. 42 (citing ICCPR, procedural rules for ad hoc international criminal tribunal, and then-current draft statute for international criminal court); Loizidou, 310 Eur. $C t$. H.R. (ser. A) at 22, 25, para. 57, 67 (discussing treaty practice generally and referring to the Statute of the International Court of Justice and the Vienna Convention on the Law of Treaties).

118. See, e.g., Loizidou, 310 Eur. Ct. H.R. (ser. A) at 22, para. 57 (citing scholarly works on state responsibility and on obligations to follow international law in occupied territories).

119. See, e.g., Murray, 1 Eur. Ct. H.R. at 62-63 (Pettiti, J., joined by Valticos, J., partly dissenting) (objecting to majority's approval of use of adverse inferences from silence on ground that it contradicts both common law and civil law traditions).

120. See, e.g., Saunders, 24 Eur. Ct. H.R. at 2063, para. 66 (acknowledging contribution of amicus Liberty, a nongovernmental organization); Akdivar v. Turkey, 15 Eur. Ct. H.R. at 1199, para. 13 (1996) (citing amicus participation by Amnesty International); cf. supra note 16 (commenting on the role of civil liberties groups and other organizations in U.S. litigation that spawned decisions recognizing rights of the accused).

121. See, e.g., Murray, 1 Eur. Ct. H.R. at 56-57, para. 74-79 (ordering the United Kingdom to pay $£ 15,000$, minus legal-aid fees, to a defendant whom it had denied access to counsel during first 48 hours of police detention).

122. The European court's jurisprudence is like that of the U.S. Supreme Court not only in its methods, but also in its frequently expressed desire to effect fundamental fairness. See supra text accompanying notes 15-31; cf. Ryssdall, supra note 109, at 23 ("The theme that runs through the Convention and its case law is the need to strike a balance between the general interest of the community and the protection of the individual's fundamental rights."). One commentator, invoking the U.S. Supreme Court era in which many individual-rights cases were decided, has called the European Court of Human Rights "a Warren Court in the midst of Europe." Gordon Van Kessel, European Perspectives on the Accused as a Source of Testimonial Evidence, 100 W. VA. L. REv. 799, 802 (1998).

123. See Ryssdall, supra note 109, at 22 ("The Court's position as a quasi-constitutional court for the whole of Europe is now widely accepted."); see also Sibrand Karl Martens, Opinion: Incorporating the European Convention: The Role of the Judiciary, 1 EUR. HUM. 
conforming to the court's interpretation of the Convention. ${ }^{124}$ Some states, like the Netherlands, enforce the Convention directly in their own courts. ${ }^{125}$ Even in England, long a laggard in the European integration process, a new statute increased the Convention's domestic applicability. ${ }^{126}$

The Convention's principles matter outside Europe as well. Its terms inspired other regional human rights conventions. ${ }^{127}$ The seminal opinion of the European Court of Human Rights regarding inhuman treatment has spawned litigation and judgments

RTS. L. REV. 5, 9-10 (1998) (predicting that court will move even more toward "the role of a constitutional court that lays down common standards" now that all members must submit to court's jurisdiction). Besides the founding states mentioned, see supra note 107, members are Albania, Andorra, Austria, Bulgaria, Croatia, Cyprus, Czech Republic, Estonia, Finland, Germany, Georgia, Greece, Hungary, Iceland, Latvia, Liechtenstein, Lithuania, Macedonia, Malta, Moldova, Poland, Portugal, Romania, Russia, San Marino, Slovakia, Slovenia, Spain, Switzerland, Turkey, and Ukraine. See The 41 Member States of the Council of Europe, supra note 107.

124. See Ryssdall, supra note 109 , at $20 \mathrm{n} .4$ (using as example Dutch legislation that shortened permissible delay between arrest and appearance before magistrate, in response to Brogan v. United Kingdom, 152B Eur. Ct. H.R. (ser. A) at 40 (1989), which found a violation of the Convention's guarantee that detainee will be brought promptly before magistrate); Triffterer, supra note 47 , at 478.

125. Regarding the Netherlands, see Bradley, Convergence, supra note 1, at 480-81; Martens, supra note 123, at 7, 10-13. Regarding other states, see Ákos Farkas \& Erika Róth, The Constitutional Limits of the Efficiency of Criminal Justice, 37 ACTA JURIDICA HUNGARICA 139, 145 (1995-96) (describing effect in Hungary); Ari-Matti Nuutila, The Reform of Fundamental Rights and the Criminal Justice System in Finland, 37 ACTA JURIDICA HUNGARICA 303, 304-06 (1995-96); Jörg Polakiewicz \& Valérie Jacob-Foltzer, The European Human Rights Convention in Domestic Law: The Impact of Strasbourg Case-Law in States Where Direct Effect Is Given to the Convention, 12 HuM. RTS. L.J. 65 (1995) (discussing direct effect in more than a dozen European states); Jacob W.F. Sundberg, The European Convention on Human Rights and Criminal Procedure in Sweden, in CRIMINAL SCIENCE IN A GLOBAL SOCIETY: ESSAYS IN HONOR OF GERHARD O.W. MUELLER 109 (Edward M. Wise ed., 1994); infra text accompanying note 131 (describing European Union endorsement of Convention). But see James D. DINNAGE \& JOHN F. MURPhY, THE CONSTITUTIONAL LAW OF THE EUROPEAN UNION 102-03 (1996) ("The Convention ... does not have the same interpretative effect as the U.S. Bill of Rights ... due to the lack of direct applicability and uniformity of the Convention and the interplay between contracting states' own constitutions and the Convention's principles.").

126. See Human Rights Act, 1998, ch. 42 (Eng.), reprinted in 38 I.L.M. 464 (1999). This act requires national courts to "take into account" the rights set out in the European Convention. Id. § 2. National legislation must be read as much as possible to be compatible with the Convention. See id. $\$ 3$. Although a law deemed incompatible may remain valid, such a declaration may trigger amendment of the law. See id. $\$ \S 304,10$; see also Bert Swart \& James Young, The European Convention on Human Rights and Criminal Justice in the Netherlands and the United Kingdom, in CRIMINAL JUSTICE IN EUROPE: A COMPARATIVE STUDY, supra note 46, at 57,62 (noting that although England joined the Convention at its outset, it accorded the Convention value only as a subsidiary source of law).

127. See Ryssdall, supra note 109, at 22 (describing European Convention as a model for the American Human Rights Convention, supra note 98, and for the African Human Rights Charter, supra note 98). 
in the U.N. Human Rights Committee and in national courts in North America, Europe, and Africa. ${ }^{128}$ Some of its opinions now guide the ad hoc international criminal tribunals. ${ }^{129}$ Thus the Convention, as interpreted by the European Court, fosters agreement about the rights of the accused.

\section{European Union}

Also providing impetus for convergence is the ongoing process of European integration. It began not long after the conclusion of the European Human Rights Convention, when a number of European states established communities to coordinate economic activity. Today those communities comprise the European Union. Its charters, or constitutive treaties, established a quasi-federal entity, complete with executive, legislative, and judicial organs. ${ }^{130}$ The treaties included no

128. See Pratt v. Attorney General for Jamaica, [1994] 2 App. Cas. 1 (P.C. 1993) (appeal taken from Jam.) (en banc) (relying on Soering, see supra text accompanying note 113, to declare that extended time on death row could violate ban on inhuman punishment in Jamaican Constitution); Catholic Commission for Justice \& Peace in Zimbabwe v. Attorney General, [1993] 1 Zimb. L. Rev. 239 (ZS) (visited Mar. 31, 2000), <http: //www.law.wits.ac.za/salr/ catholic.html $>$ (extending reach of Soering and holding that prolonged stay on death row violated proscription against cruel, inhuman or degrading treatment or punishment in Constitution of Zimbabwe); Kindler v. Canada, (U.N. H.R. Comm. July 30, 1993), reprinted in 14 HUM. RTs. L.J. 307 (1993) (sustaining Canadian Supreme Court's rejection of Soeringbased claim in Kindler v. Canada (Minister of Justice), [1991] 2 S.C.R. 779, on ground that instant case was distinguishable from Soering); accord Lackey v. Texas, 514 U.S. 1045 (1995); infra note 356. But see Sudden Spate of Executions Is Sweeping Caribbean, N.Y. TIMES, June 9, 1999, at A7 (reporting on efforts in Barbados, amid regional calls for capital punishment, to amend its Constitution to overrule Pratt).

129. See, e.g., Prosecutor v. Furundzija, No. IT-95-17/1-T 10, Judgement, paras. 143-164, 170-171 (Dec. 10, 1998), available in ICTY, Furundzija Judgement (visited Apr. 21, 2000) $<$ http://www.un.org/icty/furundzija/trialc2/judgment/main.htm> (citing European Court of Human Rights opinions in discussing international proscription against torture); Prosecutor v. Delalić, No. IT-96-21-T, Judgement, paras. 161, 451-52 (Nov. 16, 1998), available in United Nations Celebici Judgement (visited Apr. 21, 2000) <http://www.un.org/icty/celebici/trialc2/ jugement/main.htm> (relying on European Court of Human Rights opinions for rule of statutory interpretation and for customary international law regarding torture); Prosecutor v. Blaskić, No. IT-95-14-AR108, Decision of the Objection of the Republic of Croatia to the Issuance of Subpoenae Duces Tecum, para. 54 (July 18, 1997), available in Decision on the Objection of the Republic of Croatia to the Issuance of Subpoena Duces Tecum (visited Apr. 21,2000 ) <http://www.un.org/icty/blaskic/trialc1/decisions-e/70718SP2.htm> (drawing on European Court of Human Rights opinion to support its position that Croatia has a duty to cooperate with ICTY investigation). For more on these international tribunals, see infra text accompanying notes $162-78,200-04$.

130. See Treaty Establishing the European Economic Community, Mar. 25, 1957, arts. 137188, 298 U.N.T.S. 11, 67-68, amended by Treaty Establishing a Single Council and a Single Commission of the European Communities, Apr. 8, 1965, 4 I.L.M. 776 [hereinafter European Treaty] (discussing European Parliament, Council, Commission, Court of Justice, and Court of Auditors); see also DINNAGE \& MURPHY, supra note 125, at 83-86 (deriving constitutional law of the European Union from its treaties and its establishment of Parliament and Court of Justice). The other two constitutive treaties are the Treaty Instituting the European Coal and 
Bill of Rights; however, all branches have committed themselves to respect the fundamental rights embodied in the European Human Rights Convention. ${ }^{131}$ Through these developments, member states have shed absolute sovereignty in favor of what Professor Anne-Marie Slaughter has called "permeable sovereignty"-a "network" in which each government is "constrained by the activities of individuals and groups operating in transnational civil society." 132

Because of its initial limitation to economic concerns, the Union's organs seldom considered questions relating to human rights. ${ }^{133}$ That has changed, however, as the Union's compass has expanded to include political, cultural, domestic, and foreign policy matters. ${ }^{134}$ In recent years, for example, the Union has required foreign aid recipients to conform to its own human rights standards. ${ }^{135}$ Moreover, as the Corpus

Steel Community, Apr. 18, 1951, 261 U.N.T.S. 140, and the Treaty Establishing the European Atomic Energy Community, Mar. 25, 1957, 298 U.N.T.S. 167.

All 20 European Commissioners recently resigned after an experts' report concluded that they had mismanaged the hundred billion dollar budget. See Roger Cohen, Mouse That Roared: European Parliament Stands up, N.Y. TIMEs, Mar. 17, 1999, at A8. Some observers urged a shift in legislative power to the European Parliament and away from the Commission, which is an unelected body that also wields executive power. See id.

131. In 1977, three European Community institutions affirmed "the prime importance they attach to the protection of fundamental rights, as derived in particular from the constitutions of the Member States and the European Convention," and promised to "continue to respect these rights." Joint Declaration by the European Parliament, the Council and the Commission, 1977 O.J. (C 103) 1. The Maastricht Treaty made this pledge mandatory, stating that the "Union shall respect fundamental rights, as guaranteed by the European Convention ... and as they result from the constitutional traditions common to the Member States, as general principles of Community law." Treaty on European Union, art. F(2), 1992 O.J. (C 224) 1 (entered into force Nov. 1, 1993) [hereinafter TEU]; see also DINNAGE \& MURPHY, supra note 125, at 97-98 (stating that Maastricht Treaty and opinions of the European Court of Justice had "remedied" initial absence of human rights guarantees).

132. Anne-Marie Slaughter Burley, A New Look at an Old Debate, 87 AM. SoC'Y INT'L L. Proc. 133, 138 (1993); see also Zenon Bankowski \& Andrew Scott, The European Union?, in CONSTITUTIONALISM, DEMOCRACY AND SOVEREIGNTY: AMERICAN AND EUROPEAN PERSPECTIVES, supra note 30, at 86-88 (describing transformation in Europe from supreme sovereigns to "interlocking systems" within same territory).

133. See Sally J. Kenney, The Judges of the Court of Justice of the European Communities, in Constitutional Dialogues IN COMPARATTVE PERSPECTIVE 143, 145 (Sally J. Kenney et al. eds., 1999) (noting that European Court of Justice opinions dwelt on economic rather than human rights issues).

134. See TEU, supra note 131, tits. V-VI (setting out policies relating to foreign and home affairs); European Treaty, supra note 130, pt. 3 (discussing Community policies in, for instance, agricultural, economic and monetary, social and educational, cultural, consumerprotection, and environmental sectors).

135. See generally T. King, Human Rights in the Development Policy of the European Community: Towards a European World Order?, 28 NETH. Y.B. INT'L L. 51, 52 (1997) (stating that European Union embarked on this "ambitious" policy in 1991). The United States likewise conditions receipt of foreign aid on adherence to human rights principles. See Kristin N. Wuerffel, Note, Discrimination Among Rights?: A Nation's Legislating a Hierarchy of Human Rights in the Context of International Human Rights Customary Law, 33 VAL. U. L. REV. 369, 391 n.152 (1998) (listing U.S. statutes setting such conditions and requiring the 
Juris discussion below demonstrates, attention to domestic affairs will require integration of the inquisitorial and accusatorial methods of criminal procedure. ${ }^{136}$

In early years the European Community had a civil law perspective. But the accession in the 1970s of common law states, the United Kingdom and Ireland, necessitated blending of the two juridical systems. ${ }^{137}$ The convergence began just after the French Revolution had proceeded, ${ }^{138}$ so that aspects of each method had continued to infiltrate the other. In common law systems, attorney-directed jury trials now occur less often, ${ }^{139}$ and the standing police forces once unique to the inquisitorial method are routine. ${ }^{140} \mathrm{~A}$ right to silence now constrains examinations of the accused in civil law systems, ${ }^{141}$ though pressures to plea-bargain increase the incidence of self-incrimination in common law systems. ${ }^{142}$ Meanwhile, common law characteristics like an investigating prosecutor and a defense right to present evidence have a place in civil law courts. ${ }^{143}$ Some commentators thus have gone so far as to

executive branch to report annually to Congress on countries' human rights practices).

136. See infra text accompanying notes 162-89 (discussing Corpus Juris); supra text accompanying notes 45-55 (discussing two criminal procedure methods).

137. Today the Union has 15 members: Austria, Belgium, Denmark, Finland, France, Germany, Greece, Ireland, Italy, Luxembourg, the Netherlands, Portugal, Spain, Sweden, and the United Kingdom. See European Treaty, supra note 130, art. 138.

138. See supra text accompanying notes 56-61.

139. Because of overburdened criminal dockets, high costs, and incentives to settle, as many as $95 \%$ of all criminal cases in the United States end without jury trials. See Bradley, Convergence, supra note 1 , at 482 . The cases end not by the inquisitorial tradition of short bench trials, but rather by the U.S. innovation of the plea bargain-an innovation that itself has been adopted in some civil law systems. See id. at 473-74; see also Craig M. Bradley, Overview, in CRIMINAL PROCEDURE: A WORLDWIDE STUDY at xvi-xvii n.2 (Craig M. Bradley ed. 1999). This convergence away from the jury trial is likely to change common law as well as civil law rules. See DAMAŠKA, supra note 48, at 138-39, 149.

140. See Jörg et al., supra note 46, at 48 (describing common law states' adoption of police forces); $c f$. United States v. Wade, 388 U.S. 218, 224-25 (1967) (noting that there were no organized police forces in the United States at the time the Bill of Rights was adopted).

141. See Bradley, Convergence, supra note 1, at 475 ("A right against self-incrimination at trial, and against involuntary confessions, is now generally enforced."); Pieck, supra note 29, at 585 (remarking that all Western European countries recognize some form of privilege against self-incrimination); see also Madlener, supra note 52, at 250 (stating that right was first inserted into German code after World War II); Vogler, supra note 54, at 32-33 (noting that although a defendant in France now has a right to remain silent, it is seldom exercised because the defendant still must appear repeatedly before judicial officers).

142. See, e.g., Van Kessel, supra note 122, at 844-45 (maintaining that, because of plea bargaining, "the American justice system is even more dependent than European systems on forcing admissions of guilt from defendant's mouth," and permits more coercive techniques to obtain confessions); Vogler, supra note 54, at 72 ("French jurists would argue that the English concept of the 'guilty plea' encourages the police to extort confessions by improper means, safe in the knowledge that the resulting pragmatic decision to plead guilty will effectively hide their activities from judicial enquiry.").

143. See CURRIE, supra note 91, at 152 (explaining that GRUNDGESETZ [Constitution][GG] art. 103 I (F.R.G.) has been held to be a right "to present one's case"); $\$ 151$ art. 20 II StPO (setting forth Akkusationsprinzip, or accusatory principle, which commits to the prosecutor, and not to a judge, the duty of investigating a complaint and filing public charges); Delmas- 
dismiss debate about the two methods as passé. ${ }^{144}$ Nevertheless, each method retains much of its original form, and aspects of each method continue to draw fire. ${ }^{145}$ Scholars still debate which method is more fair. ${ }^{146}$

Notably, that debate rests on common ground: a commitment to fairness, one that may be traced to medieval and Enlightenment philosophers in England and on the continent. ${ }^{147}$ Both the common law and the civil law systems required the penal

Marty, supra note 2, at 192-93 (noting the increased abandonment of the juge d'instruction in civil law countries); Stephen P. Freccero, An Introduction to the New Italian Criminal Procedure, 21 AM. J. CRIM. L. 345 (1994) (noting Italy's adoption of adversarial aspects, including relegation of judge to role of monitoring opposing attorneys and a form of plea bargaining).

144. See Françoise Tulkens, Criminal Procedure: Main Comparable Features of the National Systems, in THE CRIMINAL PROCESS AND HUMAN RIGHTS, supra note 2, at 5, 8 (maintaining that aspects of each method now occur in the other to a degree that distinguishing the two "is almost a 'metaphysical question' which is now sterile and obsolete").

145. An oft-criticized facet of the accusatorial method is plea-bargaining, which places great pressure on defendants to waive fair trial rights in hope of a more lenient sentence. See supra note 142. Critics of the inquisitorial method focus attention on retention of the juge d'instruction, discussed supra text accompanying note 59. See, e.g., Madlener, supra note 52, at 240 (stating that in Spain the examining judge "has wide powers of investigation and once he has established proof of facts against the defendant it is well nigh impossible to destroy this proof at the trial"); Vogler, supra note 54, at 28, $71-72$ (maintaining that the institution puts the defense at a disadvantage by repeatedly subjecting the defendant to questioning). But see id. at 31, 51 (acknowledging French view that such questioning benefits the defense by allowing an early establishment of innocence or explanation of conduct).

146. See, e.g., Bradley, Convergence, supra note 1, at 473 (stating that while the rightsbased accusatorial method may seem "more fair," it affords the prosecution far more resources than the defense, in contrast with the neutral balance of the judge-directed inquisitorial method); Delmas-Marty, supra note 2, at 192-93 (criticizing accusatorial method for failing to provide equality of resources); MichaelN. Schmitt \& Steven A. Hatfield, Scientific Evidence in Courts-Martial: From the General Acceptance Standard to the Relevancy Approach, 130 MIL. L. REv. 135, 144 (1990) (arguing that civil law system offers fairer trial because judge, not prosecutor, controls inquiry free from evidentiary constraints).

A heated exchange occurred in the 1970s. Compare Abraham S. Goldstein \& Martin Marcus, The Myth of Judicial Supervision in Three "Inquisitorial" Systems: France, Italy, and Germany, 87 YALEL.J. 240 (1977) (criticizing states using inquisitorial method; in particular, criticizing French system for lack of judicial oversight of police), with John H. Langbein \& Lloyd L. Weinreb, Continental Criminal Procedure: "Myth" and Reality, 87 YALE L.J. 1549, 1554-60, 1569 (1978) (criticizing Goldstein \& Marcus article as taking French and German practices out of context, asserting that dissatisfaction with the criminal justice system is greater in the United States than in Europe, and concluding "that it is foolish ... to suppose that the whole explanation for our dissatisfaction can be found in a greater commitment to the ideal of justice").

147. See Jörg et al., supra note 46 , at $42,53,56$ ("[A]t some level each system aspires to both the truth and a fair trial."); Schlesinger, supra note 57, at 363 (stating that both methods share roots in "teachings of 18th-century thinkers"); cf. DAMAŠKA, supra note 48, at 13-14 n.17 (tracing origin of exclusionary rule not to U.S. case law, but rather to centuries-old continental tradition banning evidence obtained in violation of "a defendant's 'natural rights"'). 
process to respect individual liberty and to guarantee the individual equal footing within the criminal justice administration. Such fairness was to be assured by structural means like separation of powers and procedural means like recognition of the rights of the accused..$^{148}$ In common law systems the concept made its debut in the English Magna Carta, ${ }^{149}$ won prominence in the U.S. Constitution and Bill of Rights, and reached a zenith in the U.S. Supreme Court doctrine of fundamental fairness.

A prime source for the concept in the civil law systems was the French Revolutionary Déclaration des droits de l'homme et du citoyen. ${ }^{150}$ Issued in the same period as the U.S. Declaration of Independence, Constitution, and Bill of Rights, the Déclaration shared aspects with those documents. Like the Declaration of Independence, it proclaimed as "inalienable" rights of individuals" ${ }^{151}$ concepts like liberty ${ }^{152}$ and equality. ${ }^{153}$ Like the Constitution, it called for a government in which power would be shared among an executive, legislature, and judiciary. ${ }^{154}$ Like the Bill of Rights, it enumerated specific rights, including the freedom of religion and the rights of an accused. ${ }^{155}$ In contrast with the Declaration of Independence, the

148. Rules of criminal procedure were considered the "first line of defense" against abuse by the government. See Tulkens, supra note 144, at 5-7 (attributing this theory to Enlightenment philosophers such as Beccaria, Voltaire, and Montesquieu).

149. A pact reached in 1215 between the English king and nobles, the Magna Carta provided that "[n]o free man shall be taken, or imprisoned, or disseised, or exiled, or in any way destroyed, nor will we go upon him, nor send upon him, except by the lawful judgment of his peers or by the law of the land." MAGNA CARTA, ch. 39 (1215), reprinted in WILLIAM SHARP MCKECHNIE, MAGNA CARTA-A COMMENTARY ON THE GREAT CHARTER OF KING JOHN 375 (2d rev. ed. 1914) (bracketed insertions of "and" instead of "or" omitted). An early U.S. Supreme Court opinion traced the Due Process Clause of the Fifth Amendment to the U.S. Constitution to this passage. See Den v. Hoboken Land \& Improvement Co., 59 U.S. (18 How.) 272, 276 (1855). For a discussion of fundamental faimess, see supra text accompanying notes 15-31.

150. Déclaration des droits de l'homme et du citoyen du 26 aout 1789 (adopted by the National Assembly), reprinted in LIBERTÉs ET DROITS FONDAMENTAUX, supra note 33, at 41. For an English translation, see Declaration of the Rights of Man and of the Citizen, reprinted in THE FRENCH IDEA OF FREEDOM: THE OLD REGIME AND THE DECLARATION OF RIGHTS OF 1789, at 3 (Dale Van Kley ed., 1984) [hereinafter Declaration of the Rights of Man].

151. Compare Declaration of the Rights of Man, supra note 150, at 1 (setting forth "the natural, inalienable, and sacred rights of man"), with THE DECLARATION OF INDEPENDENCE para. 2 (U.S. 1776) (proclaiming that "all men ... are endowed by their Creator with certain unalienable rights"). See also Gerald J. Postema, In Defence of 'French Nonsense': Fundamental Rights in Constitutional Jurisprudence, in ENLIGHTENMENT, RIGHTS AND REVOLUTION, supra note 3, at 107.

152. See Declaration of the Rights of Man, supra note 150, art. 2 (listing liberty as a "natural and imprescriptible right ["); id. art. 4 (defining liberty); THEDECLARATIONOF INDEPENDENCE para. 2 (identifying as natural rights "Life, Liberty, and the pursuit of Happiness").

153. Compare Declaration of Rights of Man, supra note 150, art. 1 ("Men are born and remain free and equal in rights."), and id. art. 6 (discussing equality before the law), with THE DECLARATION OF INDEPENDENCE para. 2 ("[A]11 men are created equal ....").

154. See Declaration of the Rights of Man, supra note 150, art. 16 ("A society in which the guarantee of rights is not secured, or the separation of powers not clearly established, has no constitution.").

155. Compare U.S. CONST. amend. I (guaranteeing free exercise of religion and barring 
Déclaration, like the U.S. Constitution and Bill of Rights, has the force of law. ${ }^{156}$

Protections accorded the individual are explicit in laws elsewhere in Europe. Many constitutions, particularly in states once controlled by authoritarian governments, contain detailed enumerations of fundamental rights. ${ }^{157}$ Germany's Constitution transforms fundamental rights into "positive constitutional law," directly enforceable against all branches of government. ${ }^{158}$ Germany further requires that criminal procedures honor those rights; indeed, its criminal procedure statute has been deemed to implement its Constitution. ${ }^{159}$ Accordingly, if indeed the "overall trend" in the civil law and common law systems "is in the direction of a common middle," legal philosophy, one that should ease convergence, ${ }^{161}$ informs that trend.

\section{Corpus Juris}

One indicator of such a trend began in 1995, when the European Parliament appointed a group of experts to define crimes that threaten the financial health of the European Union and to develop a uniform procedure for investigating, prosecuting,

establishment of same), andid. amends. IV-VI (listing rights of the accused, including freedom from unreasonable searches and seizures, privilege against self-incrimination, and right to counsel), with Declaration of the Rights of Man, supra note 150, art. 7 (forbidding arbitrary accusation, arrest, or detention), id. art. 8 (proscribing ex post facto prosecutions), id. art. 9 (guaranteeing presumption of innocence), and $i d$. art. 10 (forbidding undue interference with one's religion). See generally JOHN BELL, FRENCH CONSTITUTIONAL LAW 66, 69, 73 (1992) (citing Article 10 as the origin of freedom of religion as a French constitutional value).

156. The preamble to the French Constitution proclaims an "attachment to the rights of man," as defined by the Déclaration and confirmed by the preamble to the 1946 Constitution. FR. CONST. pmbl. para. 1 (1958), reprinted in LIBERTÉs ET DROITS FONDAMENTAUX, supra note 33 , at 51,51 . The Conseil constitutionnel, France's constitutional court, has accorded this proclamation "supreme legal value," in a decision one commentator likened to Marbury v. Madison, 5 U.S. (1 Cranch) 137 (1803) (holding that U.S. judiciary has power to review constitutionality of laws). Gicquel, supra note 92, at 237-38. Although judges in other French courts may not employ the constitutional values embodied in the Déclaration to nullify a law, they may refer to those values to fill gaps in the law. See Delmas-Marty, supra note 33, at 27.

157. See Delmas-Marty, supra note 33, at 11 (listing as such "countries more sensitive to the risk of totalitarianism" Germany, Spain, Bulgaria, Romania, Poland, and the Czech Republic).

158. Götz, supra note 91 , at 79.

159. See I EBERHARD SCHMIDT, LEHRKOMMENTAR ZUR STRAFPROZEBORDNUNG UND ZUM GERICHTSVERFASSUNGSGESETZ 81, at annot. 99 (2d ed. 1964) (describing the Strafsprozeßordnung, or German criminal procedure statute, as "Ausführungsgesetz zum GG"; that is, as "an implementation of the Grundgesetz," or Basic Law, Germany's Constitution) (citation omitted).

160. Bradley, Convergence, supra note 1 , at 475.

161. But see DAMAŠKA, supra note 48 , at $149-50$ (highlighting, as barriers to importation of civil law methods into common law, absence in latter of "a civil service judiciary and a body of investigative officials perceived by the prevailing political consciousness as neutral"). Professor Damaska continues: "In looking at the most updated Continental evidence law for inspiration, Anglo-American lawyers are thus often likely to discover modifications of ideas of common law provenance. This should refer them back to their own legal culture, there to seek indigenous remedies for the ailments of their decaying institutions." Id. at 150. 
and punishing those crimes. ${ }^{162}$ In an apparent nod to the Justinian code on which many European civil law codes are based, the group titled its 1997 report Corpus Juris. ${ }^{163}$ The report first maintained that the removal of barriers to trade among European states had stimulated more cross-border crime. ${ }^{164}$ Yet criminal justice administration remains largely an internal matter. Individual states disagree on what conduct constitutes a crime, on rules of criminal procedure and evidence, on appropriate penalties, and on the proper degree of international cooperation. ${ }^{165}$ These disagreements not only transform certain states into safe havens for criminals, ${ }^{166}$ but also result in unjust, unequal treatment. ${ }^{167}$

The Corpus Juris report rejected three conventional European Union means to coordinate efforts of its member states. "Assimilation"-requiring member states to combat fraud against the Union the same way they would combat domestic fraud-and "cooperation"-use of treaty-based forms of mutual assistance in investigation-both were deemed ineffective. ${ }^{168}$ More aggressive alignment of disparate policies-labeled "harmonisation"169 - was seen as too complex. ${ }^{170}$ Thus the report recommended a "radically new" approach, "unification." 171 Rather than permit

162. See CORPUS JURIS back cover, 6 (Mireille Delmas-Marty ed., 1997).

163. See, e.g., Edward A. Tomlinson, Judicial Lawmaking in a Code Jurisdiction: A French Saga on Certainty of Price in Contract Law, 58 LA. L. REV. 101, 105 (1997) (describing historical significance of Byzantine Emperor Justinian's sixth-century Corpus Juris Civilis).

164. See CORPUS JURIS, supra note 162, at 12; cf. Delmas-Marty, supra note 2, at 195 (Delmas-Marty, editor of Corpus Juris, asking, "Who could deny that the opening of the borders, like the development of a criminality called 'transnational,' obligates the European states to arrive at a common criminal law policy?").

165. See CORPUS JURIS, supra note 162 , at 14.

166. See id. at $12 \mathrm{n} .2,14$; see also id. at 40 (decrying this situation as an "absurdity").

167. See id. at 14,34-36 (describing injustices worked by disparities in individual states' law of evidence).

168. Id. at 14-18; see id. at 40 . Respecting cooperation, the report noted that with the exception of the convention against money laundering, few states had ratified existing mutual legal assistance conventions. See id. at 18. Moreover, cooperation requires officials in one state to interpret disparate doctrines of another state. If states' laws are incompatible, evidence attained in one state will be inadmissible in another. See id. at 26-28.

169. The report described "harmonisation" as a move toward "greater uniformity, in order to reduce the most glaring differences between national laws, without actually going as far as to impose rules that are identical." Id. at 28; $c f$. GEORGE A. BERMANN ET AL., CASES AND MATERIALS ON EUROPEAN COMMUNITY LAW 79, 429-30 (1993) (describing harmonization as a frequently invoked goal of European Community legislation).

170. CORPUS JURIS, supra note 162 , at 40 . Because of this complexity, lawyers in individual states had resisted applying this concept. See id. at 38 . The promises of harmonization-efficiency and elimination of disparities that work injustices on "economic operators" whose conduct might affect the financial status of the Community-had not been realized. Id. at 38 .

171. Id. at 40; $c f$. Christine Van Den Wyngaert, Une perspective "eurocentrique" sur la répression de la délinquance transnationale européenne: le projet espace judiciaire européenne et le corpus juris, in LES SYSTÈMES, supra note 47, at 443, 444 (explaining that "experts introduced a 'vertical' dimension" to combating fraud against the Union in order to sidestep problems with "'horizontal' approach, based on interstate cooperation in penal matters"). 
national courts to try to accommodate different legal practices, Corpus Juris would establish one set of laws to govern a select group of crimes, all of which bring financial harm to the European Union. ${ }^{172}$

In a truly radical step, the report then proposed a system of investigation and adjudication that would combine aspects of both the accusatorial and the inquisitorial methods. ${ }^{173}$ As in the former, an independent prosecutor, called the European Prosecution Service, would undertake to investigate the case. ${ }^{174}$ As in the latter, a judge would handle the preparatory phase. ${ }^{175}$ This judge would not be an investigator for the state, but rather an independent, impartial judge charged with ensuring that a suspect's rights are not infringed during investigatory matters such as use of wiretaps and issuance of arrest and search warrants. ${ }^{176}$ The judge thus would not be called a juge d'instruction, or investigating judge, but rather a juge des libertés, or judge of freedoms. ${ }^{177}$ The prosecution service would be "an authority of the European Community," but the judge of freedoms would be part of the member state's judiciary. ${ }^{178}$ Trials and initial appeals would occur in national courts, albeit based on the Corpus Juris law and with limited right of appeal to the European Court of Justice. ${ }^{179}$

172. CORPUS JURIS, supra note 162, at 40 (including crimes of fraud in the Community budget, market-rigging, corruption, abuse of office, misappropriation of funds, disclosure of secrets pertaining to one's office, money laundering, and conspiracy that harms the Community's budget). The report explained:

This is not a criminal code, nor a unified code of European criminal procedure made directly applicable everywhere by European courts set up for the purpose. What we propose is a set of penal rules, which constitute a kind of corpus juris, limited to the penal protection of the financial interests of the European Union, designed to ensure, in a largely unified European legal area, a fairer, simpler and more efficient system of repression.

Id.; see also Mireille Delmas-Marty, The European Union and Penal Law, 4 EUR. L.J. 87, 107 (1998) (asserting that unification should take place only with respect to crimes affecting the financial interests of the European Union; in other spheres, states should continue to work to harmonize their criminal procedure).

173. Discounting the differences between the two systems at the trial level, the report commented that the fair trial guarantee in the European Human Rights Convention "tends to bring different national practices closer together, including on how witnesses are heard." CORPUS JURIS, supra note 162 , at 116.

174. See id. at 82-86. This prosecutor would operate under uniform rules, eliminating the "long, complex procedures of bilateral cooperation" under existing methods, such as mutual legal assistance treaties, extradition, and letters rogatory. Id. at 86.

175. See id. at 110-12.

176. See Van Den Wyngaert, supra note 171, at 445.

177. See CORPUS JURIS, supra note 162, at 110-12; Triffterer, supra note 47 , at 489 (approving of term juge des libertés for judge whose "role is not to investigate but rather to protect civil liberties and to guarantee procedural rights"); see also Van Den Wyngaert, supra note 171 , at 445 .

178. CORPUS JURIS, supra note 162 , at $82-84,112$.

179. Id. at 114-22. Only professional judges would be permitted to decide such cases, ostensibly to reduce the risk of error. See id. at 118. 
A similar blending would occur with respect to fundamental rights. Reflecting the shared commitment to rights of the accused, the report incorporated and expanded upon the rights guaranteed in the ICCPR and the European Convention on Human Rights. ${ }^{180}$ An individual would be entitled to full notice of charges, to assistance of counsel, and to remain silent as soon as she were named an accused. ${ }^{181}$ An accused also would benefit from an express presumption of innocence, a right not to assist in establishment of her own guilt, limitations on which of her statements might be used against her, and a rule mandating exclusion of evidence obtained in violation of fundamental rights. ${ }^{182}$ Balancing these defense rights would be victim's rights. In accord with civil law practice, the victim of the crime-the European Commission-would have the status of a partie civile, entitled to seek compensation even as the prosecutor sought punishment. ${ }^{183}$

A central value animated the Corpus Juris recommendations. The report argued that the new procedures should evince the principle of procédure contradictoire; that is, that all parties in a criminal proceeding must be allowed full opportunity to be informed of and to contest evidence, in order that a fair and just verdict ensues. ${ }^{184}$ Although procédure contradictoire derives from the continental tradition, both civil law and common law systems embrace aspects of the principle, which serves a shared concern for fairness. ${ }^{185}$ The report advocated applying the principle at more stages of the proceedings than either system does, enhancing the potential for fairness. ${ }^{186}$ Thus

\section{See id. at $40,122-24$.}

181. See id. at 124. Corpus Juris sought to correct a fault found in both the European Convention on Human Rights and the ICCPR by requiring that a person be considered "an accused," and thus entitled to all rights of an accused, as soon as a step is taken to develop evidence of guilt against the person. Id. at 124-26.

182. See id. at 130-38.

183. See id. at 124, 128-30; cf. Vogler, supra note 54, at 25-27 (describing role of partie civile in French criminal litigation). Though alien to the common law system, the partie civile concept is itself the subject of convergence. A 1986 U.N. declaration urged states to adopt fair and speedy means for victims to obtain redress, including, perhaps, attachment of a civil claim to criminal proceedings. See MATTI JoutSEN, THE ROLE OF THE VICTIM OF CRIME IN

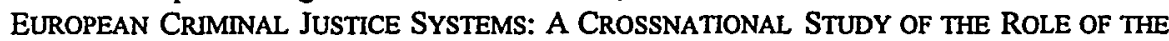
VICTIM 307 (HEUNI Publication Series No. 11, 1987) (discussing Declaration of Basic Principles of Justice for Victims of Crime and Abuse of Power, G.A. Res. 40/34, U.N. GAOR, 40th Sess., Supp. No. 53, at 213, U.N. Doc. A/40/53 (1986)).

184. See CORPUS JURIS, supra note 162, at 80, 124; $c f$. Delmas-Marty, supra note 2, at 197 ("The ideal is the contradictory debate; that is to say, the rejection of revealed, uncontested truth replaced by facts which are contested and only th[e]n established as truths.").

185. See In re Oliver, 333 U.S. 257 (1948) (establishing right to public trial as a central component of due process); MARTIN VRANKEN, FUNDAMENTALS OF EUROPEAN CIVIL LAW 203-04 (1997) (describing the principle of a public trial at which parties may be heard and defend themselves as "a general principle of law" in both France and Germany).

186. See CORPUS JURIS, supra note 162, at 124. The report elaborated:

The underlying idea is that the evidence will be more reliable if it has been subject to this kind of hearing, which of course it is only to a very partial extent in inquisitorial proceedings, and only very late in the day in accusatorial proceedings-in practice only at the trial. For this reason, the provisions proposed would mean progress everywhere as regards the quality of the proceedings. 
Corpus Juris suggested a path to development of a body of criminal procedure that shares not only legal technique, but also legal philosophy. ${ }^{187}$ Though still under study, ${ }^{188}$ the proposal well may succeed in some form, as existing conventions and case law, ongoing political and economic integration, and the need to combat rising cross-border crime continue to bring European criminal justice systems into tune. ${ }^{189}$

\section{E. Toward Truly International Enforcement}

Similar concerns encourage convergence outside the European Union. States across the globe seek to combat crime in a manner that wins them the respect of the world community. Such political acceptance may be a precursor, or a prerequisite, of full integration into the global economic community. As described below, these considerations have given rise to a new era of law enforcement. Individual states, sometimes responding to external pressure, are conforming their criminal justice systems to international standards. Meanwhile, truly international adjudication of crime is under way for the first time since the Nürnberg trials.

\section{Influence of Nongovernmental \\ Organizations}

States' desire for political and economic discourse often gives nongovernmental human rights organizations a means to goad change. To this end, Amnesty International and Human Rights Watch, among others, publish annual reports reviewing the degree to which each state abides by the fair trial rights embodied in the ICCPR. ${ }^{190}$ The American Bar Association helps draft democratic constitutions in

Id.

187. See Van Den Wyngaert, supra note 171, at 445 (stating that Corpus Juris "presupposes a common system of judicial guarantees," one that has in large part been achieved given that all European Union members also are bound to adhere to the European Human Rights Convention); cf. Triffterer, supra note 47, at 488 (maintaining that "if criminal codes are oriented" to ensure rights of suspects, "it does not matter to what extent the adversarial or inquisitorial model is established").

188. The report was presented to the European Parliament in April 1997; subsequently, the Parliament ordered further study of the proposal. See Van Den Wyngaert, supra note 171, at 445-46.

189. See CORPUS JURIS, supra note 162 , at $40,122-24$. Professor Delmas-Marty wrote in an earlier essay:

it is beyond question that, to a degree, everywhere in Europe the criminal process has ceased to function within a closed circuit.... And the consequences could be remarkable because in detaching itself from the artificial in order to approach the living, the machine of criminal justice could move toward a greater "functioning as a whole" and at the same time a "lesser functioning as its constituent parts." ... A complexity which presages, at the same time-because the evolution is comparable from one country to another-, anew design of the [legal] landscape. Delmas-Marty, supra note 2, at 195 (alteration in original) (citation omitted).

190. See Human Rights Watch, World Report 1999 (visited Mar. 15, 2000) $<$ http://www.hrw.org/hrw/worldreport99/>; Amnesty Int'l, 1998 Amnesty International Annual 
the former Soviet republics. ${ }^{191}$ These groups and others, among them the Lawyers Committee for Human Rights and the Fédération Internationale des Ligues des Droits de l'Homme, distribute analyses of proposals related to international criminal tribunals. ${ }^{192}$ Representatives of hundreds of human rights organizations lobbied at the 1998 Rome conference that concluded the statute for the proposed International Criminal Court. ${ }^{193}$ Such groups routinely participate, both as lead counsel and as amici curiae, in human rights litigation before national and international courts. ${ }^{194}$

Nongovernmental organizations also try to inculcate international rights of the accused at the grass roots, by representing defendants in national courts and by training others to do so. Thus in Rwanda, Lawyers Without Borders provides legal

Report (visited Mar. 15, 2000) <http://www.amnesty.org/ailib/aireport/ar98/index.html>.

191. See Janet Key, CEELI: Old Countries, New Rights, A.B.A. J., May 1994, at 68, 69 (noting as well efforts to combine, in new Eastern European legal systems, the common law and civil law traditions).

192. See La Fédération Internationale des Ligues des Droits de l'Homme, Pour la Paix, Par la Justice (June 15, 1998), numéro 745-746, lettre du 14 au 21 mai 1998 (visited Mar. 15, 2000) <http://www.fidh.imaginet.fr/actu/cpi/PAIX.HTM>; Human Rights Watch, Justice in the Balance: Recommendation for an Independent and Effectlve International Criminal Court (visited Oct. 30, 1999) <http://www.hrw.org/reports98/icc/>; Lawyers Committee for Human Rights, Establishing an International Criminal Court: Major Unresolved Issues in the Draft Statute (visited Mar. 14, 2000) <http://www.lchr.org/icc/pap1 rev.htm>; Amnesty Int'l, The International Criminal Court: Preliminary Comments Concerning the Elements of War Crimes Other than Grave Breaches of the Geneva Conventions - Part I (July 1999) (visited Mar. 31, 2000) $<\mathrm{htpp} /$ www.amnesty.org/ailib/aipub/1999/IOR/14001 199.htm>; AMERICANBARASS'N, REPORTOF THE TASK FORCEON AN INTERNATIONAL CRIMINAL COURTOF THE AMERICAN BAR ASSOCIATION 32-33 (1995).

193. Hundreds of individuals, representing more than 200 nongovernmental organizations ("NGOs") from throughout the world, took part in the Rome conference. See Some Words from William Pace, Convenor of the Coalition for an International Criminal Court, ONTHERECORD 1, II 2 (Issue 14, July 7, 1998) <http://www.advocacynet.org/cgi-bin/browse.pl?id= icc14.html $>$. At their center was the NGO Coalition for an International Criminal Court, which had 800 member organizations. See Campaigners Launch a Broadside: Eleven Principles Comprise the NGO Negotiating Position, ON THE RECORD 4, I 8 (Issue 2, June 16, 1998) $<$ http://www.advocacynet.org/cgi-bin/browse.pl?id=icc02.html>. Indeed, NGOs played such a prominent role at the conference that Canada was reported to have named them "the "new superpower." Willem Offenberg, ICC Dream Factory?, ON THE RECORD 1, I 5 (Issue 5, June $19,1998)<$ http://www.advocacynet.org/cgi-bin/browse.pl?id=icc05.html>.

194. See, e.g., Saunders v. United Kingdom, 24 Eur. Ct. H.R. at 2063, para. 66 (1996) (discussing European court's acknowledgments of such participation); Rights Int'l, Rights International (visited Mar. 17, 2000) <http://www.rightsinternational.org/> (describing participation in litigation before tribunals including the inter-American and the European human rights courts, both as counsel and as amicus). Recently, Amnesty International was granted permission to argue before the British House of Lords as an intervenor in favor of extraditing Augusto Pinochet to face trial in Spain for human rights abuses that occurred during his reign as Chile's dictator. See Warren Hoge, Pinochet Wins a Round as the Law Lords Void a Ruling, N.Y. TIMES, Dec. 18, 1998, at A3. Although a panel of Law Lords initially ruled 3-2 in favor of extradition, that judgment was voided because of one judge's ties to Amnesty International. See id.; supra note 77 (describing subsequent House of Lords ruling). 
representation for defendants charged with participation in the genocide that swept that country in $1994 .{ }^{195}$ It has won some success in introducing new practices, such as cross-examination of witnesses whose reliability is suspect, into the trial procedure. ${ }^{196}$ Meanwhile, in Cambodia, where virtually all the lawyers perished during the Khmer Rouge reign in the 1970s, the Cambodian Defender Project tries to help instill a democratic legal culture founded on a constitutional criminal procedure. ${ }^{197}$ The Project trains Cambodians in all aspects of criminal defense--trial practice, substantive law, and rules of evidence. ${ }^{193}$ Encouraged to stretch accepted practice, defenders have brought motions to suppress postarrest statements, uncommon in Cambodia's civil law system, and have secured bail for their clients. ${ }^{199}$ As in Rwanda, defenders have persuaded judges to allow them to cross-examine adverse witnesses. ${ }^{200}$ These projects thus work to infuse an international concept of fairness into debilitated criminal justice systems.

\section{International Criminal Tribunals}

After the close of the Nurnberg era, no more international criminal courts convened, despite atrocities in Cambodia, Latin America, and elsewhere. Then, in the 1990 s, two tragedies sparked a new phase in international adjudication of crime. In the Bosnian region of the former Yugoslavia, many thousands suffered displacement, rape, mutilation, and murder as part of a brutal campaign known by the twisted euphemism "ethnic cleansing." 201 The death in a plane crash of Rwanda's president unleashed assaults and killings of perhaps a million members of the Tutsi group by the more populous Hutu. ${ }^{202}$ The U.N. Security Council established two tribunals- the International Criminal Tribunal for the former Yugoslavia (ICTY) and the International Criminal Tribunal for Rwanda (ICTR) - to investigate, prosecute, and

195. See James C. McKinley, Jr., Massacre Trials in Rwanda Have Courts on Overload, N.Y. TIMES, Nov. 2, 1997, at 3. They represent far fewer defendants than necessary for the hundreds of thousands of pending cases, however. See id.

196. See id.

197. See Interview with Linda Kremer, former director of the Cambodian Defenders Project, in Berkeley, Cal. (June 19, 1997) [hereinafter Kremer interview]. For a discussion of the civil dislocation that lingers 20 years after the defeat of the Khmer Rouge, see Seth Mydans, The Khmer Rouge Legacy: In the Killing Fields, Even the Future Died, N.Y. TIMES, Jan. 10, 1999, $\S 4$, at 1 .

198. See Kremer interview, supra note 197. The Project, one of a few operating in Cambodia, was founded by the International Human Rights Law Group. See id.

199. See id.

200. See id.

201. See Carol J. Williams, Bosnian Serbs Snub U.N. Chief, L.A. TnMEs, Dec. 1, 1994, at Al (stating that "ethnic cleansing" had left two million Bosnians homeless and two hundred thousand dead or missing).

202. The 1994 genocide and the incidents leading to it are described in detail in the Rwanda tribunal's first verdict. See Prosecutor v. Akayesu, Case No. 96-4-T, Judgement (Sept. 2, 1998), available in <http://www.un.org/ictr/english/judgments/akayesu.html>. For an essay on the decision, see Diane Marie Amann, International Decisions: Prosecutor v. Akayesu, 93 AM. J. INT'L L. 195 (1999). 
punish those responsible for these atrocities. ${ }^{203}$ Both tribunals had halting starts but gained respect as more suspects were captured and more trials commenced. ${ }^{204}$ Comparable tribunals have been proposed for adjudication of other international crimes. ${ }^{205}$

Like the London Charter, the Yugoslavia and Rwanda tribunals' statutes and rules combine aspects of the common law, civil law, and military law. ${ }^{206}$ As in the common law systems, an independent prosecutor leads investigation of alleged crimes, ${ }^{207}$ and cases may end with guilty pleas. ${ }^{208}$ In trials, attorneys call, examine, and crossexamine witnesses. ${ }^{209}$ As in the civil law systems, judges decide whether charges should go forward; ${ }^{210}$ at trial, judges, rather than lay jurors, decide guilt or

203. See Statute of the International Tribunal for Rwanda, S.C. Res. 955, U.N. SCOR, 49th Sess., 3453d mtg., Annex, U.N. Doc. S/RES/955 (1994) [hereinafter ICTR Statute]; Statute of the International Criminal Tribunal for the Former Yugoslavia, S.C. Res. 827, U.N. SCOR, 48th Sess., 3217th mtg., Annex, U.N. Doc. S/RES/827 (1993), reprinted in 32 I.L.M. 1203 (1993) [hereinafter ICTY Statute].

204. See, e.g., Barbara Crossette, On Eve of U.N. Rwanda Trials, Reports of Misconduct, N.Y. TIMES, Jan. 9, 1997, at A3; Barbara Crossette, World Criminal Court Having a Painful Birth, N.Y. TIMES, Aug. 13, 1997, at A10 [hereinafter Crossette, Painful Birth]; John M. Goshko, U.N. Chief Fires Top Officials of Rwanda War Crimes Tribunal, WASH. Post, Feb. 27, 1997, at A28; Elizabeth Neuffer, War Crimes Tribunal Faces Trial of Its Own: U.N. Panel Facing Fiscal Pressures, BOSTON GLOBE, May 9, 1997, at A2; Charles Truehart, War Crimes Tribunal Gathers Momentum, WASH. POST, Mar. 3, 1998, at A11.

205. A panel of experts recommended that the United Nations establish another such tribunal to try Khmer Rouge leaders who ordered massacres in the late 1970s, but the Cambodian government so far has rejected the plan. See Seth Mydans, Terms of Khmer Rouge Trials Still Elude U.N. and Cambodia, N.Y.TrMES, Mar. 23, 2000, at A3. In contrast, international prosecution of two Libyan nationals accused of bombing an airliner over Lockerbie, Scotland, is under way. See supra note 78.

206. See Crossette, Painful Birth, supra note 204; Rules of Procedure and Evidence (visited Mar. 14, 2000) <http://www.un.org/icty/basic/rpe/IT32_revl6con.htm> [hereinafter ICTY Rules] (adopted Feb. 11, 1994, as amended through July 15, 1999); Rules of Procedure and Evidence (visited Mar. 14, 2000) $<\mathrm{http}: / /$ www.un.org/ictr/rules.html $>$ [hereinafter ICTRRules] (adopted June 29, 1995, as amended through June 8, 1998).

207. See ICTY Statute, supra note 203, art. 18; ICTR Statute, supra note 203, art. 17; ICTY Rules, supra note 206, Rules 39-41; ICTR Rules, supra note 206, Rules 39-41.

208. See ICTY Rules, supra note 206, Rules 62 \& 62 bis; ICTR Rules, supra note 206, Rule 62. The ICTY Rules did not specify a procedure for receipt of a guilty plea until the twelfth revision. See ICTY Rules of Procedure and Evidence, Rule 62 bis, IT/32/Rev. 12 (Nov. 12, 1997). The first guilty plea occurred before that date, but the Appeals Chamber vacated it. See Prosecutor v. Erdemović, para. 7, No. IT-96-22-A (1998), reprinted in 37 I.L.M. 1182, 1183 (1998). The defendant successfully entered a plea after Rule 62 bis took effect. See id. para. 11. Among those pleading guilty pursuant to ICTR Rule 62 was the former Rwandan prime minister. See Prosecutor v. Kambanda, Case No. 97-23-S (1998), reprinted in 37 I.L.M. 1411 (1998).

209. See ICTY Statute, supra note 203, art. 21(e); ICTR Statute, supra note 203, art. 20(e); ICTY Rules, supra note 206, Rule 85; ICTR Rules, supra note 206, Rule 85.

210. See ICTY Statute, supra note 203, art. 19; ICTR Statute, supra note 203, art. 18; ICTY Rules, supra note 206, Rule 47; ICTR Rules, supra note 206, Rule 47. 
innocence. ${ }^{211}$ An indication of the hybrid nature of the tribunals' procedures may be the disagreement whether those procedures are predominantly inquisitorial or accusatorial. An ICTY President has characterized the rules as "largely adversarial,"212 while a leading comparative evidence scholar has described them as "continental in orientation."213

In any event, more is at play than a mechanical pasting-together of dissimilar systems. Uniting the tribunals' statutes and rules is a commitment to fundamental fairness. The U.N. Secretary General, in his report on the ICTY statute, declared it to be "axiomatic that the International Tribunal must fully respect internationally recognized standards regarding the rights of the accused at all stages of its proceedings."214 Similarly, the tribunals' Appeals Chamber has written that the ICTY was established "in accordance with the proper international standards; it must provide all the guarantees of fairness, justice and even-handedness, in full conformity with internationally recognized human rights instruments."21s Thus these ad hoc tribunals must abide not only by their own statutes and rules of procedure and evidence, but also by the fair trial guarantees in the ICCPR. ${ }^{216}$ It is this emphasis on human rights that accords the convergence of criminal procedure occurring in these tribunals a constitutional status with far-reaching implications. ${ }^{217}$

211. See ICTY Statute, supra note 203, art. 23; ICTR Statute, supra note 203, art. 22; ICTY Rules, supra note 206, Rule 87; ICTR Rules, supra note 206, Rules 87-88.

212. Statement by the President Made at a Briefing to Members of Diplomatic Missions, U.N. Doc. IT/29 (1994), quoted in 2 VIRGINIA MORRIS \& MICHAEL P. SCHARF, AN INSIDER's GUIDE TO THE INTERNATIONAL CRIMINAL TRIBUNAL FOR THE FORMER YUgOSLAVIA 650 (1995). Others agree with this characterization. See Daniel D. Ntanda Nsereko, Rules of Procedure and Evidence of the International Tribunal for the Former Yugoslavia, 5 CRIM.L.F. 507,508 (1994) (stating that ICTY "relied heavily on proposals from the U.S. government and from nongovernmental organizations such as the U.S.-based Lawyers Committee for Human Rights"); Michael P. Scharf, Trial and Error: An Assessment of the First Judgment of the Yugoslavia War Crimes Tribunal, 30 N.Y.U.J.INT'L L.\&POL. 167, 171 \& n.18(1998) (noting that a U.S. draft provided the framework for ICTY rules).

213. Mirjan R. Damaška, Propensity Evidence in Continental Legal Systems, 70 CHI.-KENT L.REV. 55, 61 n.16(1994). Nonetheless, Professor Damaska discerned common law influences in several places, among them "the provision that allows evidence of a "consistent pattern of conduct' to be introduced at trial whenever its introduction is mandated by the 'interest of justice."' Id. (citing ICTY Rules, supra note 206, Rule 93).

214. Report of the Secretary General Pursuant to Paragraph 2 of Security Council Resolution 808, U.N. SCOR, 48th Sess., para. 106, U.N. Doc. S/25704 (1993) [hereinafter Secretary General's Report].

215. Prosecutor v. Tadić, No. IT-94-1-AR72, 45-46, Appeals Chamber Decision on the Defence Motion for Interlocutory Appeal on Jurisdiction (Oct. 2, 1995) (order denying defence motion for interlocutory appeal on jurisdiction), reprinted in 35 I.L.M. 32 (1996).

216. See id. paras. 45-46; Secretary General's Report, supra note 214, para. 106; $c f$. Prosecutor v. Akayesu, No. 96-4-T, Judgement, § 1.4.1 (Sept. 2, 1998), available in $<$ http://www.un.org/ictr/english/judgments/akayesu.html> (stating that in pretrial litigation the ICTR, relying on its own statute and the ICCPR, had refused to compel another accused individual to give expert testimony at trial at bar).

217. See Theodor Meron, War Crimes Law Comes of Age, 92 AM. J. INT'L L. 462, 463 (1998) ("[T]he rules of procedure and evidence each Tribunal has adopted now form the vital 


\section{Proposed International Criminal Court}

A profound step toward convergence occurred in Rome in the summer of 1998. Culminating more than 50 years of debate, ${ }^{218}$ delegates from more than 150 countries concluded a treaty containing the statute of the proposed International Criminal Court, or ICC..$^{219}$ Scores of states already have signed, and several have ratified, the treaty. 220

Like the ad hoc tribunals, the ICC would apply hybrid procedures. As in the common law system, defendants could plead guilty; ${ }^{22 t}$ if they chose trial, they would enjoy the right to cross-examine witnesses. ${ }^{222}$ As in the civil law system, the ICC statute provides for judicial review to decide whether a case should proceed to trial. ${ }^{223}$ Trial itself would take place before a panel of judges, ${ }^{224}$ whom victims' legal representatives would be permitted to address. ${ }^{225}$ The full extent to which the two systems have been combined will not be clear until adoption of procedural and evidentiary rules, now under Preparatory Commission discussion. ${ }^{226}$

core of an international code of criminal procedure and evidence that will doubtless have an important impact on the rules of the future international criminal court."); see also supra text accompanying notes 29-31 (giving definition to term "constitutional").

218. See U.N. Committee on International Criminal Jurisdiction, Draft Statute for an International Criminal Court, G.A. Res. 489, U.N. GAOR, 5th Sess., Annex 1, at 58, UN Doc. A/AC.48/4 (1951), reprinted in 46 AM. J. INT'L L. supp. 1 (1952); Christopher Keith Hall, The First Two Sessions of the UN Preparatory Committee on the Establishment of an International Criminal Court, 91 AM. J. INT'L L. 177, 187 \& n.29 (1997).

219. See generally Rome Statute of the International Criminal Court, art. 68(3), U.N. Doc. No. A/CONF.183/9 (July 17, 1998), reprinted in 37 I.L.M. 999 (1998) [hereinafter ICC Statute]; Craig Turner, Talks on World Court Exemplify Best and Worst of U.N. Diplomacy, L.A. TMEs, July 2, 1998, at A6.

220. See CICC International Criminal Court Home Page, (visited Apr. 25, 2000) $<$ http://www.igc.org/icc/> (reporting that 96 countries have signed and 8 have ratified). Sixty states must ratify the treaty for it to enter into force. ICC Statute, supra note 219, art. 126. Even if supporting states move quickly, ratification could take at least five years. See Prepared Remarks of Professor Michael P. Scharf before the International Operations Subcommittee of the U.S. Senate Committee on Foreign Relations (July 23, 1998), available in 1998 WL 425944.

221. See ICC Statute, supra note 219, art. 65; $c f$. Roger S. Clark, The Proposed International Criminal Court: Its Establishment and Its Relationship with the United Nations, 8 CRIM. L.F. $411,430 \mathrm{n} .64$ (1997) (stating that an early proposal to let defendants before the international criminal court plead guilty rather than stand trial drew "puzzled comments from civil and Islamic lawyers").

222. See ICC Statute, supra note 219, art. 67(e).

223. See id. art. 61 . Such review by a Pre-Trial Chamber won wide support not only because it coincided with civil law tradition, but also because it was seen as an additional safeguard against overzealous, inappropriate prosecution. See Support Growing for an Independent Prosecutor: Make or Break Issue for NGO Coalition, ON THE RECORD 1 (Issue 7, June 23, 1998) <http://www.advocacynet.org/cgi-bin/browse.pl?id=icc07.html>.

224. See ICC Statute, supra note 219, arts. $62-76$ (describing role of Trial Chamber).

225. See id. art. 68(3).

226. See generally Draft Rules of Procedure and Evidence of the International Criminal 
Like the London Charter, the ICC Statute has constitutional aspects: the aspirational phrases with which it begins; ${ }^{227}$ the delineations of the separate duties of its constituent organs,;28 and the commitment to serve fundamental values like due process of law and equal protection under the laws. ${ }^{229}$ The statute includes a lengthy list of "minimum guarantees" to be afforded an accused ${ }_{2}^{230}$ and has won praise for incorporating the "principles of fairness" contained in international human rights instruments. ${ }^{231}$ Though it may be years before the ICC becomes a reality, the statute's description of fair trial rights may be seen to reflect a truly international convergence. ${ }^{232}$

Court, PCNICC/1999/DP.1 (proposal submitted by Australia, Jan. 26, 1999). One topic likely to require accommodation of the accusatorial and inquisitorial methods is the admissibility of evidence. In keeping with its doctrine of free proof, see supra text accompanying note 55, France has sought to have evidence freely admitted. See Proposal Submitted by France Concerning the Rules of Procedure and Evidence, Proposed Rule 37.1, PCNICC/1999/DP.10 (Feb. 22, 1999). Another is the precise role of the victims' legal representatives, a concept approaching the French partie civile. See Proposal by France: General Outline of the Rules of Procedure and Evidence at 6, PCNICC/1999/DP.2 (Feb. 1, 1999); see also supra text accompanying note 183 .

227. The statute states that the parties agree to establish the ICC as a means of punishing "the most serious crimes of concern to the international community as a whole . . . . [c]onscious that all peoples are united by common bonds, their cultures pieced together in a shared heritage, and concerned that this delicate mosaic may be shattered at any time" and "[m]indful that during this century millions of children, women and men have been victims of unimaginable atrocities that deeply shock the conscience of humanity," with an eye to "[r]eaffirming the Purposes and Principles of the Charter of the United Nations," and "[r] ssolved to guarantee lasting respect for the enforcement of international justice." ICC Statute, supra note 219 , pmbl.

228. See id. arts, 34-43.

229. See, e.g., id. art. 21(3) ("The application and interpretation of law pursuant to this article must be consistent with internationally recognized human rights, and be without any adverse distinction founded on grounds such as gender, . . . age, race, colour, language, religion or belief, political or other opinion, national, ethnic or social origin, wealth, birth or other status."); id. art. 55(1)(d) (barring deprivation of liberty of suspect under investigation "except on such grounds and in accordance with such procedures as are established in the Statute"); id. art. 64(2) ("The Trial Chamber shall ensure that a trial is fair and expeditious and is conducted with full respect for the rights of the accused ....").

230. Id. art. 67(1); see also id., arts. 55, 63, 64(2), 66-69 (setting forth rights of suspects and defendants, many similar to those in ICCPR, supra note 99 , art. 14).

231. La Fédération Internationale des Ligues des Droits de l'Homme, supra note 192. But see infra note 251 (describing concerns with fairness of ICC Statute).

232. The very setting of normative standards aids progress toward harmony in international law. See BASSIOUNI, supra note 103, at 4 (stating that process by which certain crimes assume international character begins with theoretical writings, then to treaties and other international undertakings, then to setting of norms, and finally to mechanisms for enforcement of those norms); BURNS H. WESTON, INTERNATIONAL LAW AND WORLD ORDER 733 (2d ed. 1990) (noting that international conventions, even if not fully effective, may act as "obstacle to retrogression" in human rights doctrines). 


\section{NOTES OF DISCORD: RESISTANCE TO A GLOBAL CRIMINAL PROCEDURE}

Clearly, components of convergence in criminal procedure abound. Their movement has been, as transnational legal process theory would predict, dynamic: forces have operated at the same time, yet in different places and forums, on both horizontal and vertical planes, and have been spurred by different actors. ${ }^{233}$ Thus, even as states have negotiated bilateral agreements on some procedures, nonstate entities like human rights groups, supranational courts, and states' own citizens have urged adoption of a spectrum of human rights norms.

Most watershed moments of convergence-the reforms just after the French Revolution, the Nurmberg trials, the rise of individual rights as a proper subject of international law, and European integration - transpired within a shared tradition, one that considers certain fundamental rights, such as fairness, liberty, and equality, inalienable. ${ }^{234}$ This is most true in Europe, where that tradition, coupled with political and economic incentives to integrate, seems likely to surmount differences in criminal procedure once deemed intractable. ${ }^{235}$ There, convergence may proceed quickly and harmoniously.

But what of states in which the fundamental rights tradition is less than firmly rooted? Will convergence pass them by, or might other elements of harmony nonetheless provoke convergence? Conversely, does an avowed commitment to principles of inalienable rights ensure that a state will stay in tune with international movements toward convergence? Or might some other factor, some element of disharmony, cause a state to diverge?

Implicit in these questions is an acknowledgment of state sovereignty. It is true that in the last half-century informal cooperation, multilateral treaties, and international organizations have drawn states into a web of interlocking obligations. And a state now may be called to account for mistreating one of its own nationals, not only by the individual, but also by other states. Such developments impinge on a state's sovereignty. In most cases, however, states retain the attributes of sovereignty that they have enjoyed for centuries. ${ }^{236}$ A state thus may choose to ignore global pulls toward compliance in service of perceived self-interest. ${ }^{237}$

In the criminal procedure arena, notes of discord may be divided loosely into the "temporal"- those that may change or pass away with time-and "structural"-

233. See supra text accompanying notes 35-43 (describing Professor Koh's theory of transnational legal process).

234. See supra text accompanying notes 56-73, 90-189.

235. See supra text accompanying note 64 .

236. The following are among the attributes commonly attached to the concept of "sovereignty": independence and autonomy from other entities in the world community, equality with other states, the legal status of an artificial person, territorial integrity, and inviolability of society and citizens as well as territory. See LOUIS HENKIN, INTERNATIONAL LAW: POLITICS AND VALUES 10-12 (1995).

237. Cf. ThOMAS M. FranCK, THE POWER of LegITIMACY AMONG NATIONS 10, 24 (1990) (positing that legitimacy - the perception that a rule or institution accords with generally accepted principles-"has the power to pull toward compliance those who cannot be compelled"). 
those that are believed to affect the structure of the state and thus to resist resolution.

\section{A. Temporal Notes}

Any number of transient, or temporal, hindrances may arise on the path to convergence. Among them are reactions to rising crime rates, lack of resources, and nagging problems remaining after uneasy political compromises.

\section{Crime}

As shown above, rising global crime has encouraged coordinated law enforcement; coordination, in turn, may encourage states to bring divergent procedures into tune..$^{238}$ Thus may rising crime compel convergence toward a global criminal procedure.

But these same developments work against what this Article has called constitutional criminal procedure-a body of law founded on principles of fundamental fairness. ${ }^{239}$ For with global cooperation comes a new threat to individual liberty. Cooperating officers are more likely to have access to the latest techniques for surveillance, techniques that encroach on individual privacy rights. And there is a sense that global criminals, because of their itinerant nature and because their conduct may have created mass fear or outrage, are less deserving of protection.

Accordingly, in states like the Republic of South Africa, still basking in praise for a constitution that enshrines individual liberties, escalating crime provokes calls for curtailment of rights. ${ }^{240}$ Other states, claiming relatively low crime rates, spurn criticism of severe punishments. ${ }^{241}$ On an international level, terrorism and drug trafficking may have replaced totalitarianism as problems believed to justify limits on civil liberties. ${ }^{242}$ Concerned about "the danger of overreaction in responses to ... organized crime," the International Association of Penal Law devoted its 1999 conference in Budapest to international law enforcement, "mainly in order to sound alarm bells about the extent to which the world-wide legislative reaction" contradicts "respect for the rule of law and the rights of the accused."243

238. See supra text accompanying notes 75-89.

239. See supra text accompanying notes 15-31.

240. See Edwin Cameron, Rights, Constitutionalism and the Rule of Law, 114 S. AFR. L.J. 504, 507-10 (1997) (decrying this trend and arguing for renewed commitment to constitutionalism).

241. See LIPPMAN ET AL., supra note 45, at 2-3 (attributing this claim to Islamic states imposing "relatively harsh Koranic penalties"); Crime Drop in Sudan Credited to Islamic Law, SEATILE TIMES, Mar. 31, 1985, at A6 (reporting that state attributed transformation of onceviolent capital, Khartoum, into one of Africa's safest cities to adoption of strict Islamic laws).

242. See Delmas-Marty, supra note 2, at 195 ("The terrorism of the large international narcotics trafficking rings seems, in extreme cases, to threaten the foundations, even of the state."); Raymond, supra note 92, at 1261-62 \& n.248 ("Terrorism' might be the next shared 'context' on which background the criminal procedure amendments are interpreted.").

243. Edward M. Wise, Foreword: The International Association of Penal Law and the Problem of Organized Crime, 44 WAYNE L. REV. 1281, 1300-01, 1303 (1998). 


\section{Lack of Resources}

Adherence to a constitutional criminal procedure-with its requirements of an impartial judiciary, independent defense attorneys, and rights to a meaningful hearing and to appeal - may be costly and cumbersome. Some states may resist convergence toward such a model simply because they lack the financial or structural resources to comply. ${ }^{244}$ Thus in Rwanda, where 100,000 detainees await trial in national courts on charges related to the 1994 massacres, a justice official questioned outside pressures to ensure defense counsel. ${ }^{245}$ Noting that few defendants had lawyers before 1994, he asked, "CCan you say that we should not punish genocide just because our country doesn't have enough lawyers?"'246

\section{Uneasy Compromises}

The Rwandan official's question speaks of more than lack of resources. It also suggests discomfort with insistence that Rwanda adopt certain rights of the accused, even though $R$ wanda to some degree has invited attention by accepting outside aid. ${ }^{247}$ Such uneasy political compromises often coincide with movements toward convergence in criminal procedure.

Even within Europe, there is unease. The Corpus Juris report, ${ }^{248}$ for example, set off a flurry of debate in London newspapers. One author warned that adoption of Corpus Juris would eviscerate English legal traditions, ${ }^{249}$ while another praised the report as "a synthesis of the best features of the rules of criminal procedure ... on both sides of the Channel."2so

Indeed, combination of the inquisitorial and accusatorial methods carries with it the seeds of unease. In the ICTR and ICTY, governed by statutes with expansive lists of

244. Alternatively, a state may choose to apply what limited resources it has to other needs considered more pressing. What kinds of rights deserve priority is a recurring question in the debates between universalists and cultural relativists, discussed infra text accompanying notes 263-66. See also Bangkok Declaration para. 6, in HUMAN RIGHTS AND CHINESE VALUES app. (Michael C. Davis ed., 1995) [hereinafter Bangkok Declaration] (asserting that "countries, large and small, have the right to ... control and freely utilize their resources").

245. See Amnesty Int'l, Rwanda: Unfair Trials: Justice Denied \$§ III, IV (last modified Apr. 8, 1997) <http://www.amnesty.org/ailib/aipub/1997/AFR/14700897.htm> (criticizing Rwanda national trials for failing to adhere to criminal procedure norms contained in human rights instruments that $R$ wanda has ratified).

246. McKinley, supra note 195, at 3 (quoting Gerald Gahima, "a high-ranking justice official").

247. See Mark A. Drumbl, Rule of Law and Lawlessness: Counseling the Accused in Rwanda's Domestic Genocide Trials, 29 ColuM. HUM. RTs. L. REV. 545, 571 n.111 (1998) (noting U.S. pledges to give millions of dollars to develop impartial tribunals).

248. See supra text accompanying notes $162-89$ (discussing report).

249. See Philip Johnston, Alarm over Euro-wide Justice Plan Threat to British Trial-by-Jury System, DAILY TELEGRAPH (London), Nov. 30, 1998, at 1 (contending that the Corpus Juris recommendations "would mark an end to historic British rights, including habeas corpus ... and trial by jury").

250. John Spencer, Fraudbusters Get Set for Euro Action, TimEs (London), Dec. 8, 1998, at 39 (article by a Cambridge professor, one of the experts who produced the report). 
rights, proceedings have drawn criticism. ${ }^{251}$ Dusko Tadic, the first defendant to appear before the ICTY, challenged limits on defense examination of prosecution witnesses $^{252}$ and the inability of the defense to secure its own witnesses. ${ }^{253}$ In both instances, parties and judges struggled to adapt a mix of legal doctrines to a hybrid situation. ${ }^{254}$

251. A report issued as the Rome ICC conference began stated that there was widespread agreement on issues related to the rights of the accused, many of which "are clearly set out in international treaties"; nevertheless,

[n]ot everyone is happy with the evolution of international criminal procedure in the Hague and Arusha courts. The French are concerned with what they view as an erosion of the continental (civil) system. The Americans feel that the proposed ICC procedures need to be more rigorously defined. They also worry that some constitutional rights might be ignored (such as the right of a defendant to know the identity of his accuser).

The Case for an International Court, ON THE RECORD 2, I 16 (Issue 1, June 14, 1998) $<$ http://www.advocacynet.org/cgi-bin/browse.pl?id=icc01.html>. For a recent commentary expressing concerns that the ICC will fail adequately to protect the accused, see Panel Discussion, Association of American Law Schools Panel on the International Criminal Court, 36 AM. CRIM. L. REV. 223, 235-38, 251-56 (1999) [hereinafter Blakesley remarks] (remarks by Professor Christopher L. Blakesley criticizing, inter alia, absence of search-and-seizure protections, inadequate pretrial protections, and vague language in ICC statute).

252. In a ruling that sparked controversy, the Trial Chamber granted the prosecution's pretrial motion to withhold from the defense, throughout trial, certain witnesses' identies. See Prosecutor v. Tadic, No. IT-94-1-T, 105 I.L.R. 419, Trial Chamber Decision on the Prosecutor's Motion Requesting Protective Measures (Aug. 10, 1995), reprinted in 7 CRIM. L.F. 139 (1996). Compare Monroe Leigh, The Yugoslav Tribunal: Use of Unnamed Witnesses Against Accused, 90 AM. J. INT'L L. 235 (1996) (criticizing decision), with Christine M. Chinkin, Due Process and Witness Anonymity, 91 AM. J. INT'L L. 75 (1997) (supporting it). Although the defendant appeared to have preserved the issue for appeal, it is not mentioned in the appellate decision. Compare Prosecutor v. Tadić, No. IT-94-1-T, Notice of Appeal of Judgement by the Defence (June 3, 1997), cited in Scharf, supra note 212, at $168 \mathrm{n.5}$, with Prosecutor v. Tadic, Case No.IT-94-1-T, Appeals Chamber Judgement (July 15, 1999)(visited Mar. 31,2000)<http://www.un.org/icty/tadic/appeal/judgement/main.htm $>$ [hereinafter Tadic Appeals Chamber Judgement].

253. The defense contended that the principle of equality of arms had been violated because Republika Srpska's refusal to help had prevented the defense from calling certain witnesses. See TadićAppeals Chamber Judgement, supra note 252, paras. 43-55. The Appeals Chamber agreed that this principle, which forbids placing a defendant at an unduly unfair disadvantage, falls within the ICTY statute's guarantee of a "fair and expeditious" trial. Id. para. 43 (quoting ICTY Statute, supra note 203, art. 20(1)). It added that it could "conceive of situations where a fair trial is not possible because witnesses central to the defence case do not appear due to the obstructionist efforts of a State." Id. para. 55. Yet it ruled against the defense on the grounds that the Trial Chamber had done all it could to assist, and that the defense had failed to seek a stay of proceedings when the difficulty arose. See id. paras. 53-55.

254. The term "equality of arms," for example, is not commonly used in U.S. criminal procedure, although the U.S. law requires equality as well as faimess. See Griffin v. Illinois, 351 U.S. 12, 17 (1956) ("Both due process and equal protection emphasize the central aim of our entire judicial system-all people charged with crime must, so far as the law is concerned, stand on an equality before the bar of justice .....) (internal quotation marks and citation 
Others complain that hybrids too readily embrace common law norms, and so deprive a defendant of some of the fairness basic to the civil law system. ${ }^{255}$ The defense attorney for a former Rwandan prefect on trial before the ICTR gave voice to these complaints. In the inquisitorial method, all parties have equal access to the entire dossier. But the ICTR, following the adversarial method, permitted documents to be furnished even after witnesses had testified. ${ }^{256}$ This, the attorney argued, rendered the defense powerless against the ICTR's "'army of police, of investigators, of prosecutors." 257 To remedy defense difficulties in obtaining documents and information from the prosecution, the attorney asked for appointment of a juge d'instruction who would inquire on behalf of both parties and make a report of the elements of the charge and of the defense. ${ }^{258}$ This request, which was not attuned to the system that had been adopted for the ad hoc tribunal, was denied. ${ }^{259}$

The obstacles just discussed are not insignificant. Nor do they seem insurmountable. Public opinion about proper crime fighting techniques, for example, could change over time, perhaps influenced by alarms sounded at events like the

omitted); see also supra note 15 . Undue circumscription of defense examination rights countermands common law doctrine that considers confrontation a fundamental right. See, e.g., U.S. CONST. amend. VI (guaranteeing an accused the right to confront adverse witnesses). Even in the United States, however, this right may give way to countervailing interests. See White v. Illinois, 502 U.S. 346 (1992) (sustaining child molestation conviction based on outof-court statements of four-year-old complainant). In contrast, it is not unusual in civil law systems for a judge to conduct nearly all examinations of witnesses. See Richard S. Frase \& Thomas Weigend, German Criminal Justice as a Guide to American Law Reform: Similar Problems, Better Solutions?, 18 B.C. INT'L \& COMP. L. REv. 317, 357 (1995) (noting that German attorneys seldom exercise their right to question witnesses). With regard to this dispute, therefore, Tadić, who was tried before a panel of professional judges according to the civil law tradition, effectively sought the benefit of common law protections developed in a different context.

255. Cf. Albert W. Alschuler, Introduction: Adding a Comparative Perspective to American Criminal Procedure Classes, 100 W. VA. L. REv. 765, 768 (1998) (maintaining that criminal procedure "convergence has proceeded almost entirely from the European side").

256. See La défense du préfet plaide Iinéquité, 50 UBUTABERA 2, ØI 23 (Nov. 23, 1998) $<$ http://www.diplomatiejudiciaire.com/Tpir/lettre50.htm> [hereinafter La défense] (quoting attorney for defendant Clément Kayishema). Compare Schlesinger, supra note 57, at 365-66 (describing extent of defense access to dossier in civil law system), with Jencks Act, 18 U.S.C. $\$ 3500$ (1994), and FED. R.CRIM.P. 16(a)(2) (permitting withholding of government witness's prior statements from defense until conclusion of direct examination).

257. La défense, supra note 256 . The attorney further complained that necessary documents were furnished late and in English rather than French, and that he had found it difficult to locate and secure the appearance of witnesses for the defense. See id. Similar complaints have been made by the lead trial attorney in the first ICTY trial. See The Prosecutor v. Dusko Tadic, 13 AM. U. INT'L L. REV. 1441, 1450, 1452 (1998) [hereinafter Wladimiroff] (presentation by Michail Wladimiroff); $c f$. Jörg et al., supra note 46, at 55 (stating that "criminal procedure in the United Kingdom has been seriously discredited by a number of miscarriages of justice that show that, without equality of arms in investigation, the partisan assumptions of the adversarial process can make a nonsense of both truth and procedural safeguards").

258. See La défense, supra note 256.

259. See id. But see Wladimiroff, supra note 257 , at 1451 (recommending that ICTY consider appointing such judges for hearing certain evidence). 
Budapest conference. Assistance, from governmental and nongovernmental organizations alike, could supply states with the resources they need to comply with international standards. Finally, further negotiation could produce more palatable political compromises. Ongoing dialogue among the European states could resolve concerns about Corpus Juris. ${ }^{260}$ Hybrid tribunals, meanwhile, could fashion institutions that protect individual liberty more than the criminal procedure methods from which they derive. Criticism of the lack of equal investigative footing, for example, might lead to appointment of a judge to oversee the pretrial process. ${ }^{261}$ In light of criticism of the civil law juge d'instruction, this might be a fully independent judge, like the Corpus Juris judge of freedoms. ${ }^{262}$ With such innovations, temporal discord may pass.

\section{B. Structural Notes}

Other notes of discord seem less amenable to change. Convergence will be impaired, for instance, if a state asked to adopt an international norm does not share the legal tradition that produced the norm, or if the state believes that adoption will threaten the state's own security or position within the world community. At the root of such resistance is a concern that adoption of the norm undermines sovereignty - the state's position of power, or its cultural identity-to a degree the state finds intolerable. Built into the nature of the state, such "structural" notes may prove difficult to dismantle.

\section{Lack of Shared Traditions}

Obviously, states that do not share a tradition of fundamental rights are less likely to move swiftly and harmoniously toward a constitutional model of criminal procedure. This disinclination implicates the enduring debate about the nature of human rights. Western tradition asserts that international conventions articulate natural, inalienable rights abiding in all cultures; ${ }^{263}$ non-Western writers and states,

260. Cf. Van Den Wyngaert, supra note 171, at 446 (acknowledgment, by one of the experts who prepared report, of room for refinement of Corpus Juris proposals).

261. Cf. Blakesley remarks, supra note 251, at 251-52 (questioning ability of ICC prosecutor to act impartially in pretrial setting); Letter from M. Cherif Bassiouni, Professor of Law, DePaul University, to Author (Mar. 21, 1999) (on file with author) (observing that defendants' rights may not be protected when prosecutor alone conducts investigations, for instance of "a mass grave investigation ... in a far away place which is not accessible to the defense," and suggesting appointment of a judge to supervise prosecutor's adherence to standards established for conducting such investigations and to ensure that all relevant information is disclosed to defense). One commentator argues that the ICC's unique nature should require special vigilance against threats to the rights of the accused and, further, should preclude any derogation from fair trial guarantees. See Sara Stapleton, Note, Ensuring a Fair Trial in the International Criminal Court: Statutory Interpretation and the Impermissibility of Derogation, 31 N.Y.U. J. INT'L L. \& POL. 535 (1999).

262. See supra text accompanying note 145 (discussing criticism of $j$ juge d'instruction); see also supra text accompanying notes 175-78 (discussing Corpus Juris's judge of freedoms).

263. See, e.g., supra text accompanying notes 96-97 (discussing Universal Declaration of 
however, often disagree. Some aver that the "conception of rights is universal," but contend that its manifestation in many international instruments too heavily reflects Western influence. ${ }^{264}$ Others acknowledge the importance of civil and political rights, yet argue that other rights, such as the right to economic development, have priority. ${ }^{265}$ Still others maintain that how a state treats its nationals is exclusively an internal, culturally determined matter. ${ }^{266}$

\section{a. Islamic States}

Many of these dissenting strains resound in Islam, a tradition far different from that of the West. Western culture is based on separation of church and state. ${ }^{267}$ But in Islam, "government, religion, and law are inseparable."268 The Islamic state thus discharges divine will. ${ }^{269}$ Contrary to the Western emphasis on fundamental rights that a state may not invade without justification, Islam stresses the duties individuals owe to the state and society. ${ }^{270}$ Islamic law, the Shari'a, derives not from human

Human Rights).

264. Mahmood Mamdani, Social Movements and Constitutionalism: The African Context, in CONSTITUTIONALISM AND DEMOCRACY 172, 172 (Douglas Greenberg et al. eds., 1993) (arguing that a sense of rights arose out of oppression, and that only by ignoring "'universal fact of revolt . . . is it possible to make human rights an invention of Western culture'") (omission added) (quoting philosopher Paulin Hountondji); accord id. at 174-78 (maintaining that Western states often advanced their own notions of human rights for political aims, such as "to substitute the discourse of reform for the discourse of revolution" and to promote "a sharp and relevant ideological critique of Soviet practice," and thus shunned interpretations of human rights more appropriate to developing world).

265. See, e.g., Bangkok Declaration, supra note 244, app. (1993 declaration of 49 Asian states, just before international conference on human rights, placing domestic concerns before civil and political rights).

266. See, e.g., China Society for Human Rights Studies, Comments on U.S. State Department Human Rights Report on China, Xinhua News Agency, June 8, 1994, available in LEXIS, Asiapc Library, Xinhua File, File No. 0608110 (making this argument, "nongovernmental academic society dedicated to study human rights" relies on Article 2 of the U.N. Charter, which grants member states "sovereign equality" and provides that the United Nations may not "intervene in matters which are essentially within the domestic jurisdiction of any state"'); see also infra text accompanying notes 295-96.

267. See supra text accompanying notes 9,155 (describing Western secularism).

268. Gravelle, supra note 9, at 1 ; see id. at 2 (declaring that nearly every Muslim state had "established Islam as the state religion"); cf. Shaheen Sardar Ali, The Conceptual Foundations of Human Rights: A Comparative Perspective, 3 EUR. PUB. L. 261, 270-71 (1997) (remarking that many scholars see secularism as source of Islamic resistance to Western human rights tradition).

269. See Bassiouni, supra note 9, at 8 (explaining that in Islam, Allah is the state's "raison d'être"); Gravelle, supra note 9, at 1-2 (noting that in most conservative Islamic states, religious leaders often also are political leaders).

270. See UNIVERSAL ISLAMIC DECLARATION OF HUMAN RIGHTS, Sept. 19, 1981, art. 19, quoted in FARHAD MALEKIAN, THECONCEPTOF ISLAMIC INTERNATIONAL CRIMINAL LAW 191 app. n.3 (1994) (stating that rights are limited as needed to serve "morality, public order and the general welfare of the Community"); Bassiouni, supra note 9, at 13 ("Unlike other sources of law, the $Q u$ 'ran emphasizes duties rather than rights. It insists upon the fulfillment of 
judgment and compromise, as in the Western view, but rather from divine revelations contained in sacred and near-sacred texts like the $Q u$ 'ran and Sunna. ${ }^{271}$ In some Islamic states interpretations of these texts have produced laws alien to a Westerner: an inferior place for women, classification of crimies according to the degree to which they offend Allah, and punishments like the cutting off of thieves' hands. ${ }^{272}$ Unlike Western states, where laws may be changed rather easily by the humans who made them, in Islamic states claims of divine mandate may thwart reform. ${ }^{273}$

Exacerbating these differences, a tense rhetoric permeates relations between the Western and the Islamic world. The West's apprehension has grown since the 1970s, when fundamentalist Muslims took over the U.S. Embassy in Iran. ${ }^{274}$ Thus the West, particularly the United States, targets antiterrorism campaigns against Islamic regions. ${ }^{275}$ Western states and organizations frequently denounce Islamic states' human rights records. ${ }^{276}$ Muslim writers, meanwhile, express bitterness about

individual obligations before the individual can claim his privileges."); id. at 23 (stating that unlike in the West, in Islam the "individual does not stand in an adversary position vis à vis the state but is an integral part thereof'); see also supra text accompanying notes 15-31, 14761 (discussing Western fundamental rights tradition); cf. Ali, supra note 268 (noting that concepts of duty and morality also have a place in Western culture, though a place less prominent than in Islam).

271. See LIPPMAN ET AL., supra note 45, at 2 (observing that Islamic "law's religious derivation and purposes are the basis of its authority, in contrast to European legal systems which derive their standing from an association with the state and its political processes"); see also Ali, supra note 268, at 265 (outlining sources of Islamic law); Bassiouni, Introduction to THE ISLAMIC CRIMINAL JUSTICE SYSTEM, supra note 9, at i, xiii-xiv; supra text accompanying notes 6, 151-54 (describing Western concept of law). But see Abdullahi A. An-Na'im, The Spirit of the Ghost of Islamic Law?, 2 GREEN BAG 2d 441, 443 (1999) (stating that these texts were themselves the product of human judgment).

272. See LIPPMAN ET AL., supra note 45, at 37-53 (explaining categories of crime and prescribed punishments); id. at 61 (noting that because of lesser status, a woman may not testify in an Islamic court; the testimony of two women, however, may substitute for that of one man).

273. See id. at 2 (stating that Islamic criminal law's essentially religious nature has made it "virtually unchangeable").

274. See LIPPMANET AL., supra note 45, at ix (noting that events like the embassy takeover and the Lebanese war had distorted Westerners' view of Islam).

275. See, e.g., Stanley Meisler, Iran Worst Terror Sponsor in '97, State Dept. Says, L.A. TIMES, May 1, 1998, at A10 (noting that Muslim states of Iran, Iraq, Libya, Sudan, and Syria are on U.S. terrorism list); Art Pine, U.S. Targets Heart of Terror, L.A. TIMES, Aug. 21, 1998, at A1 (reporting on unilateral U.S. attacks on Afghanistan and Sudan because of their alleged role in abetting Islamic fundamentalist leader believed to be behind bombings of two U.S. Embassies in Africa); James Risen, U.S. Risk of Being Targeted by World Terrorists Greater Now, Officials Say, L.A. TIMES, May 12, 1995, at 15 (blaming increased risk on recruitment, by "factions from the Middle East and elsewhere," of "extremists who no longer seem to fear getting caught").

276. Among the states that the U.S. State Department recently cited for human rights abuses-including harassment, arbitrary arrest and detention, beatings, summary judicial proceedings, suppression of dissent, and discrimination on the basis of religion and gender-were Afghanistan, Egypt, Iran, Iraq, Pakistan, Saudi Arabia, Turkey, and Yemen. See U.S. Dep't of State, 1999 Country Reports on Human Rights Practices (visited Apr. 14, 2000) 
oppression that Islamic regions suffered under European colonization. They contend that even in the post-colonial world, the West cares more to impose its own views than to reach compromise. ${ }^{277}$ Some Islamic states, like Afghanistan, ride the recent fundamentalist surge to a parochial civil society. ${ }^{278}$ These notes of discord do not promise a swift and smooth convergence of Islamic and Western criminal procedure.

Nonetheless, developments in political, legal, and intellectual spheres counsel against a jump to conclude that convergence is impossible. On a political level, the Islamic world spans several continents and subcultures, and not all states with majority Muslim populations have systems as strict as that in, say, Saudi Arabia. ${ }^{279}$ The more secular states have made some moves to accommodate views of human rights that prevail outside the Islamic world. Egypt, for example, has permitted women to sue for divorce, while Turkey has agreed to obey the requirements of the European Human Rights Convention. ${ }^{280}$

On a juridical level, Islamic criminal procedure has evolved in a way that bears resemblance to both the inquisitorial and the accusatorial methods. ${ }^{281} \mathrm{As}$ in the

<http://www.state.gov/www/global/human_rights/1999_hrp_report/overview.html>;see also Human Rights Watch, World Report 1999 (visited Apr. 14, 2000) $<\mathrm{http} / / / \mathrm{www} . \mathrm{hrw}$. org/hrw/worldreport99/intro/index.html\#top> (highlighting abuses in Afghanistan, Algeria, Iraq, Saudi Arabia, and Sudan).

277. See Ali, supra note 268, at 282 (stating that the "human rights discourse in the Islamic tradition has not been approached in the true intellectual spirit of engaging in a dialogue of 'equals," and suggesting that the legacy of European colonialism of Islamic regions promotes this unevenness); accord Bassiouni, supra note 9, at 18 (observing that "western Orientalists" still call for Islamic law to "modernize in the sense of becoming secular").

278. See Dexter Filkins, Afghans Pay Dearly for Peace, L.A. TIMES, Oct. 22, 1998, at A1 (describing seizure of power by Taliban, an "extreme" Islamic group); see also Bassiouni, supra note 271, at ix (commenting that Iran, Pakistan, and Sudan recently replaced secular with Islamic law); Gravelle, supra note 9, at 1 (noting recent rise of Islamic fundamentalism, and consequent adoption of Shari' $a$, in parts of the Mideast, West Africa, and the Philippines).

279. See LIPPMAN ET AL., supra note $\mathbf{4 5}$, at 53 (stating that there are 800 million Muslims in the world, constituting a majority in 35 states and a large minority in 20 others); Bassiouni, supra note 271, at xiv-xvi (noting many variations of Islam); Gravelle, supra note 9, at 2 (dividing Islamic states into four groups, ranging from most religious, such as Saudi Arabia and Afghanistan, to most secular, Turkey).

280. See Susan Sachs, Egypt's Women Win Equal Rights to Divorce, N.Y. TIMES, Mar. 1, 2000 , at A1; see also Koh, supra note 35, at $675 \mathrm{n} .257,677$; supra note 123 (listing Turkey among states that have submitted to jurisdiction of European Court of Human Rights). Despite some concern that integration of Turkey may "water down" European human rights standards, the Court of Human Rights has issued sanctions against Turkey for violation of the European Convention. See, e.g., Aydin v. Turkey, App. No. 23178/94, 25 Eur. H.R. Rep. 251, 251 (1998) (ordering compensation for woman raped in custody, in violation of Convention's prohibition against torture); Koh, supra note 35, at 677 (stating concern, yet noting that movement will occur in other direction as well).

281. See MALEKIAN, supra note 270 , at 165 (stating that differences in procedure are "slight"); Bassiouni, supra note 9, at 41 (remarking that in many Muslim states, judicial procedures follow a "western model"). Notably, the Shari' $a$ and similar texts say little about criminal procedure; in this field, therefore, claims that a certain procedure has divine origin are weak. See id. at 39; Tāhā J al 'Alwānī, The Rights of the Accused in Islam, 10 ARAB L.Q. 3, 7 (1995); Awad M. Awad, The Rights of the Accused Under Islamic Criminal Procedure, in 
former, a judicial officer oversees proceedings. ${ }^{282}$ As in the latter, an adversarial confrontation between accuser and accused is a cornerstone of procedure. ${ }^{283}$ Even more than in the common law systems, however, Islamic rules limit evidence at trial to that considered most reliable: eyewitness testimony, confessions, and oathtaking. ${ }^{284}$ Judgment is to be based on this evidence alone. ${ }^{285}$

On an intellectual level, some Muslim scholars stress that the Shari'a is an interpretation of divine law, not divine law itself, and thus argue that it may be reformed. ${ }^{286}$ These scholars find in the Islamic texts a core commitment to the dignity of the individual, one that demands the protection of human rights. ${ }^{287}$ Included are

THE ISLAMIC CRIMINAL JUSTICE SYSTEM, supra note 9, at 91, 93 (noting that procedure is not outlined in Shari' $a$ and thus is within the domain of political authorities); cf. Bassiouni, supra note 9 , at 42 (acknowledging absence of uniform, contemporary code of Islamic criminal procedure, and calling for same).

282. See al 'Alwānī, supra note 281, at 5-8 (setting out role of judicial officer as impartial and obligated to serve truth); Osman Abd-el-Malek al-Saleh, The Right of the Individual to Personal Security in Islam, in THE ISLAMIC CRIMINAL JUSTICE SYSTEM, supra note 9, at 71 (identifying as one of the safeguards of the Islamic system the requirement that only a designated judicial official, and not police, may conduct interrogations); Bassiouni, supra note 9, at 39 (noting central role of judge in Islamic criminal justice); $c f$. supra text accompanying notes 47-50, 52-55 (describing roles of judges in inquisitorial and accusatorial methods).

283. See, e.g., al-Saleh, supra note 282 , at 76 (describing Islamic system as essentially accusatorial, particularly in the form of the trial); Awad, supra note 281, at 94 (explaining interrelation between accusation and presentation of defense); cf. supra text accompanying notes 46-61, 138-43 (outlining conduct of trials in Western methods). But see LIPPMANET AL., supra note 45 , at 70 (noting that, unlike Western systems, witnesses may not be crossexamined).

284. See LIPPMANET AL., supra note 45, at 68-72; id. at 69 (noting that $Q u r$ 'an specifies the number of witnesses necessary to prove each serious crime); Ma'amoun M. Salama, General Principles of Criminal Evidence in Islamic Jurisprudence, in THE IsLAMIC CRIMINAL JUSTICE SYSTEM, supra note 9, at 109,115-20,122 (explaining that evidence is confined to testimony, confessions, and presumptions in furtherance of accused's right to dignity and presumption of innocence). Thus hearsay and documentary evidence have no place in Islamic courts. See LIPPMAN ET AL., supra note 45, at 70; cf. supra text accompanying notes 48, 54 (describing treatment of evidence in inquisitorial and accusatorial methods). But see Bassiouni, supra note 271 , at xviii (contending that "the policy of the Shari' $a$ " requires Islamic courts to admit improved means, such as scientific evidence).

285. See Salama, supra note 284 , at 110-12 (stating that although there is some dispute, Islamic criminal law requires judge to ignore personal knowledge and to render a guilty verdict only if evidence "clearly and convincingly" proves the accusation).

286. See, e.g., Ali, supra note 268, at 269 (maintaining that the Shari' $a$ is a construct of Muslim jurists and thus reformable (citing ABDULLAHI AHMED AN-NA'IM, TOWARD AN ISLAMIC REFORMATION 185 (1990)); Bassiouni, supra note 271, at xiv (stating that through "disciplined interpretation... Islam can provide the solution to contemporary social problems through the rule of law").

287. See, e.g., MALEKIAN, supra note 270, at 168 (stating that rights of accused "have always existed in the main sources of Islamic law, but have not always been appropriately exercised within the political structure of Islamic states and their constitutions-which have integrated some of the Islamic legal philosophies into their provisions but have exercised them negatively for political purposes"); Ali, supra note 268, at 269-70 (citing Qu'ranic verse and 
fair trial rights, ${ }^{288}$ among them a right to remain silent, the rights to be free from torture or arbitrary detention, a presumption of innocence, and a right to assistance of counsel. ${ }^{289}$

\section{b. China}

As a state with a cultural tradition at odds with that of the West, China represents an archetype of how structural obstacles may affect convergence. Unlike the Western philosophy of individual autonomy, in Chinese culture the individual must serve the interests of the collectivity. ${ }^{290}$ The priority of the state is a tenet of ancient Confucianism, one that has survived in the Communist concept of democratic centralism. ${ }^{291}$

For the first three decades of Communist rule, China had no criminal code or set of criminal laws, a situation one author attributed to Mao Zedong's "preference for 'rule by man' ... over 'rule of law." 292 The criminal procedure code instituted in the

sayings of Muhammad regarding respect for human dignity); Bassiouni, supra note 9, at 19 ("In Islam the dignity of man is foremost for he is the prize creation of Allah; equality and justice are therefore a natural corollary.").

288. See Bassiouni, supra note 9 , at 15 (finding principles of due process and fair trial in Islamic sources stating, for instance, "Allah enjoineth justice and kindness").

289. See, e.g., LIPPMAN ET AL., supra note 45, at 61-66 (listing these and related rights of accused); MALEKIAN, supra note 270, at 166-68 (same); Tāhā J al 'Alwānī, The Rights of the Accused in Islam (Part Two), 10 Arab L.Q. 238, 238-47 (1995) (same); al-Saleh, supra note 282, at 65-81 (same); Awad, supra note 281, at 94-107 (same); cf. UNIVERSAL IsLAMIC DECLARATION OF HUMAN RIGHTS, supra note 270, pmbl., arts. IV-V (declaring as "enjoined by Islam" numerous rights to justice and to fair trial); al "Alwānï, supra note 281, at 14-16 (noting that Allah's declaration of home as sacred limits power to search or conduct surveillance); Ali, supra note 268 , at 277 (citing individuals' property rights against others and the state). But see LIPPMAN ET AL., supra note 45 , at $75 \mathrm{n} .45$ (stating that in practice, parties seldom are represented by counsel).

290. See, e.g., Ronald J. Troyer, Chinese Thinking About Crime and Social Control, in SOCIAL CONTROL IN THE PEOPLE'S REPUBLICOF CHINA 45, 51 -52 (Ronald J. Troyer et al. eds., 1989); see also supra text accompanying notes 15-31, 147-61 (discussing Western view). This basic divergence in ideals may fuel overt recriminations, as in the recent furors over the NATO bombing of the Chinese Embassy in Belgrade and over Chinese espionage in U.S. nuclear facilities. See Doyle McManus, Report Sharpens Edginess with China, L.A. TIMES, May 26, 1999 , at A18.

291. See Robert Davidson \& Zheng Wang, The Court System in the People's Republic of China with a Case Study of a Criminal Trial, in COMPARATIVE AND INTERNATIONAL CRIMINAL JUSTICE SYSTEMS: POLICING, JUdiCIARY AND CORRECTIONS 139, 147 (Obi N. Ignatius Ebbe ed., 1996) (stating that Chinese system reflects a Confucian ideal, placing health of society above rights of individual); Lucian W. Pye, The State and the Individual: An Overview Interpretation, in THE INDIVIDUAL AND THE STATE IN CHINA 16 (Brian Hook ed., 1996) (describing priority of the state in both Confucianist and Communist China); Min Zhou, A Comparative Analysis of Contemporary Constitutional Procedure, 30 CASE W. RES. J. INT'L L. 149, 182, 221-25 (1998) (explaining Communist concept of democratic centralism, or "democratic dictatorship," by which power traditionally was concentrated in a single state entity).

292. See Wei LuO, THe 1997 Criminal Code of the People's Republic of China 3 (1998); accord Mingxuan Gao \& Binzhi Zhao, De la réforme du nouveau code pénal chinois, 
late 1970s differed greatly from the constitutional criminal procedure model; moreover, defendants enjoyed no privilege against self-incrimination, no presumption of innocence. ${ }^{293}$ Critics, including some U.S. government officials and numerous nongovernmental organizations, have contended that China abuses the human rights of its people. ${ }^{294}$

China has rebuffed such criticism, arguing that human rights are not universal but culturally determined. ${ }^{295}$ It has insisted that critics improperly tread on its sovereignty and meddle in its internal affairs. ${ }^{296}$ At a 1993 conference in Bangkok, it persuaded forty-nine Asian states to sign a declaration placing domestic concerns such as sovereignty and development before civil and political rights. ${ }^{297}$ And the Chinese have accused the United States, in particular, of using "dual criteria on the issue of human rights" by condemning China in areas in which the U.S. record is not untarnished. ${ }^{298}$

1998 REVUE DE SCIENCE CRIMINELLE ET DE DROIT PÉNAL COMPARÉ 479, 480 (stating that before enactment of first code, politics played a principal role in punishment of crime); $c f$. Min, supra note 291, at 165, 182 (finding seeds of rule by man in generations of imperial rule and in absence of procedural laws).

293. See Yingyi Situ \& Weizheng Liu, An Overview of the Chinese Criminal Justice System, in COMPARATIVE AND INTERNATIONAL CRIMINAL Justice SYSTEMS: POLICING, JUdiciaRY AND CORRECTIONS, supra note 291, at 125, 130. Work began on the first code in 1950, but it went through 38 revisions before it was enacted 29 years later. See Gao \& Zhao, supra note 292 , at 479 .

294. See, e.g., Aminesty International, The Death Penalty In China: Breaking RECORDS, BREAKING RULES (1997); ASIA WATCH, DETAINED IN CHINA AND TIBET (1994); David Manasian, Can International Law Establish Universal Human Rights? The Conscience of Mankind, ECONOMIST, Dec. 5, 1998, at 3 (describing degree to which reports about human rights abuses have motivated Western politicians to demand reform in China); Diane F. Orentlicher \& Timothy A. Gelatt, Public Law, Private Actors: The Impact of Human Rights on Business Investors in China, 14 Nw. J. INT'L L. \& Bus. 66, 66 (1993) (noting debate over most-favored-nation trade status for China, prompted by China's 1989 repression of Tiananmen Square dissidents); Daphne Huang, Comment, The Right to a Fair Trial in China, 7 PAC. RIM L. \& POL'Y J. 171, 177-78 (1998) (citing critiques by nongovernmental organizations).

295. See supra text accompanying notes 263-66 (setting forth contentions of cultural relativists, all of which China has advanced).

296. See Michael C. Davis, Chinese Perspectives on Human Rights, in HUMAN RIGHTS AND CHINESE VALUES, supra note 244, at 3, 17 (quoting the foremost Chinese delegate at a 1993 U.N. human rights conference in Vienna as saying that " $[t]$ o wantonly accuse another country of abuse of human rights and impose the human rights criteria of one's own country or region on other countries or regions are tantamount to an infringement upon the sovereignty of other countries and interference in the latter's internal affairs"') (alteration added).

297. See Bangkok Declaration, supra note 244; see also China Carries the Day at Human Rights Conference, AGENCE FRANCE-PRESSE, Apr. 3, 1993, available in 1993 WL 10706532 (describing China's lead, supported primarily by Burma, Indonesia, and Singapore, but opposed by Japan).

298. China Society for Human Rights Studies, supra note 266. A Chinese report noted that the United States has criticized China for prosecuting "counter-revolutionary criminals," even though U.S. law also makes insurrection a crime, and for "indiscriminately and wantonly arresting and maltreating criminals," even though U.S. prisons hold a far higher percentage of 
China nonetheless has made overtures to placate its critics. ${ }^{299}$ Even as the Bangkok Declaration asserted sovereign control over human rights, for example, it acknowledged that human rights have a universal nature ${ }^{300}$ In 1988 , China joined the international convention condemning official torture. ${ }^{301}$ In 1996, it adopted a new Criminal Procedure Law, with features that included an expanded right to counsel, a right to active legal defense, and an express prohibition on coerced confessions. ${ }^{302}$ "If fully implemented," the U.S. State Department has written, "this law would bring criminal laws closer toward compliance with international norms." ${ }^{303}$ The number of executions appears to have dropped markedly. ${ }^{304}$ China has established a legal aid

the total population than China's. Id; accord Erik Eckholm, Tensions Rise Before Albright's China Trip, N.Y. TIMEs, Feb. 28, 1999, $\S 1$, at 8 (relating the Chinese government's "predictably tart response" to 1999 State Department report criticizing China for human rights abuses).

299. See China's Judicial Guarantee for Human Rights Forceful: Official, XINHUA NEWS AGENCY, Mar. 31, 1997, available in LEXIS, Asiapc Library, Xinhua File (quoting Zhang Xiufu, Vice-Minister of Justice, as linking changes in laws to "reform and opening up" of China); see also Davis, supra note 296, at 11-12 (noting Chinese government's "increasing tendency to attempt to justify its policies in human rights terms"); Eckholm, supra note 298 (asserting that "Chinese leaders are anxious to sustain friendly ties" with the United States, because they "know that American technology and cooperation are vital to their economic progress and that American culture is widely admired among the population"); Elizabeth Olson, China Tries To Fend off U.N. Censure over Rights, N.Y.TimEs, Mar. 21, 1999, § 1, at 9 (reporting on China's "vigorous campaign to head off possible censure of its human rights record" at meetings of the U.N. Human Rights Commission).

300. See Bangkok Declaration, supra note 244, paras. 5, 9; Davis, supra note 296, at 18 (stating that for this reason the declaration may represent "progress" in receptiveness of Asian states to universality of human rights).

301. See United Nations, U.N. Treaty Collection Website (visited Mar. 10, 2000) $<$ http://www.un.org/Depts/Treaty/final/ts2/newfiles/part_boo/iv_boo/iv_9.html> (reflecting China's ratification of the Convention Against Torture and Other Cruel, Inhuman, Degrading Treatment or Punishment, G.A. Res. 39/46, U.N. GAOR, Annex, Supp. No. 51, at 197, U.N. Doc. A/39/51 (1984)). The United States did not ratify this convention until 1994. See id.

302. See Amended PRC Criminal Procedure Law, Mar. 17, 1996, arts. 32-39 [hereinafter PRC Criminal Procedure Law] (setting out right to assistance of counsel or other representatives) (unofficial English translation provided by Xinhua News Agency, Mar. 24, 1996, on file with the Indiana Law Journal); id. art. 43 (proscribing coerced confessions). Other aspects of the law that resonate with the constitutional criminal procedure model include the right to have proceedings conducted in one's native language, provisions for pretrial release on bail, full examination and cross-examination of witnesses, procedures for arrest and warrants, rights to public proceedings in many cases, and a right to an appeal. See id. arts. 9 , $47,51-58,71,111,151-52,180$.

303. U.S. Dep't of State, 1999 Country Reports on Human Rights Practices: China (visited Apr. 14, 2000)<http://www.state.gov/www/global/human_rights/1999_hrp_report/china. $\mathrm{html}>$ [hereinafter China Country Report]. Two Chinese law professors likewise argue that in articulating a principle of legality, the new law limits the state's power of punishment, a limitation that will lead to autonomy, democracy, and the rule of law. See Gao \& Zhao, supra note 292 , at 486.

304. See Elisabeth Rosenthal, Number of Executions in China Seems To Decline, Rights Group Says, N.Y. TIMES, Sept. 4, 1998, at A3 (describing Amnesty International report that 
foundation ${ }^{305}$ and has explored with Western jurists different methods of trying criminal cases. ${ }^{306}$ After a 1998 visit by Mary Robinson, the U.N. High Commissioner for Human Rights, China signed the International Covenant for Civil and Political Rights. ${ }^{307}$ Ratification would obligate China to abide by a host of fair trial rights. ${ }^{308}$

Stimulating change has been China's "opening to the outside world"; that is, its desire for a larger role in the world economic arena. ${ }^{309}$ In recent decades China has cultivated a domestic market economy and secured avenues for overseas trade. ${ }^{310}$ It seeks entry into the World Trade Organization. ${ }^{311}$ This new discourse with the external world has fostered internal interest in Western concepts of democracy and human rights. ${ }^{312}$ Indeed, two Chinese law professors recently asserted that the interpenetration of domestic and foreign criminal laws, in a manner that will lead to greater democracy in China, is "an irreversible trend." 313

But the new Criminal Procedure Law does not fully embrace the notion that an individual enjoys fundamental rights against the state. In accord with Chinese collectivist tradition, reportage about the law speaks of "legitimate rights" or "rights as established by law."314 These terms connote rights that the state confers and may

about 3000 people were executed in 1997, compared to 4367 in 1996, yet noting that "China still executes far more people than any other nation"); accord Gao \& Zhao, supra note 292, at 492 (stating that the new PRC Criminal Procedure Law reduces instances in which a death sentence may be levied).

305. See National Legal Aid Foundation Established, XINHUA NEWs AGENCY, May 26, 1997, available in LEXIS, Asiapc Library, Xinhua File, Item No. 0526248; see also James Podgers, Forging a Far East Alliance, A.B.A. J., Jan. 1999, at 89, 89 (describing American Bar Association plans to help train and otherwise cooperate with legal aid attorneys in China).

306. See A Bank Robbery Trial Catches Chinese Legal Experts' Attention, XINHUA NEWS AGENCY, Oct. 30, 1998, available in LEXIS, Asiapc Library, Xinhua File, Item No. 1030089 (describing demonstrations of trial procedures sponsored by the Ford Foundation in conjunction with the Beijing State Judges College, the American Bar Association, and the Berlin Judges Association).

307. See As China Signs Rights Treaty, It Holds Activist, N.Y.TIMES, Oct. 6, 1998, at A13.

308. See supra text accompanying notes 99-102 (describing contents of ICCPR).

309. Gao \& Zhao, supra note 292, at 491; see also id. at 480, 490-91 (pointing to the significance of this opening in the evolution of 1997 PRC Criminal Procedure Law).

310. See id. at 480 (discussing changes wrought by market economy). Reciprocal desire for trade has at times caused the West to compromise; in the early 1990s, for instance, the United States chose not to link most-favored-nation trading status to improvements in China's human rights practices. See Jim Mann, China Called Clinton's Bluff on Human Rights Diplomacy, L.A. TIMES, Sept. 10, 1996, at A1.

311. See Erik Eckholm \& David Sanger, U.S. Reaches an Accord To Open China Economy as Worldwide Market, N.Y. TIMES, Nov. 16, 1999, at A11 ("For China, membership in the trade group would mean a long-sought acceptance into 'club' of world power.").

312. See Davis, supra note 296, at 21-23 (emphasizing importance of increasing diversity of human rights perspectives within China).

313. Gao \& Zhao, supra note 292, at 490 . A third Chinese law professor, though not as emphatic, also has contended that development of a market economy should continue to provoke greater attention to, and adaptation of, Western legal institutions. See Min, supra note 291 , at 149, 181, 249. Cf. Huang, supra note 294, at 195-96 (predicting that both internal and external forces will effect change in China).

314. E.g., National Legal Aid Foundation Established, supra note 305 ("equal rights as 
revoke, unlike the "inalienable" or "natural" rights at the heart of the Western tradition. ${ }^{315}$ Furthermore, the prefatory paragraphs of the new law list ten societal goals, such as protection of the state and the people. In contrast, only one goal, avoidance of prosecuting the innocent, clearly implies a right of the individual against the state. ${ }^{316}$ Rights that a defendant may have under the new law sometimes must be inferred, and there is no enumeration of rights comparable to those in international instruments. ${ }^{317}$ Nor do the passages resonate with the values underlying the constitutional criminal procedure model. For example, Article 12 states: "No-one shall be convicted without a verdict pronounced by a people's court according to the law," a statement that might imply a guarantee of due process. ${ }^{318}$ Nowhere, however,

established by law"); Judicial Guarantees for Human Rights Strengthened in China: Paper, XINHUA NEWS AGENCY, Mar. 31, 1997, available in LEXIS, Asiapc Library, Xinhua File, Item No. 0331039 [hereinafter Judicial Guarantees] ("legitimate rights and interests of citizens"); Commentary: Law Amendments for Better Checks and Balances, XINHUA NEWS AGENCY, Mar. 14, 1996, available in LEXIS, Asiapc Library, Xinhua File, Item No. 0314225 [hereinafter Commentary] (same).

315. See supra text accompanying notes 150-56 (discussing U.S. Declaration of Independence and French Déclaration des Droits de l'Homme); Davis, supra note 296, at 11 (stating that in China, "rights are not inherent in humanhood as under natural rights doctrine but are created by the State").

316. The new Chinese procedural law states:

ARTICLE 1. This law is enacted in accordance with the constitution to guarantee the correct implementation of criminal laws; punish crimes; protect the people; safeguard state, social and public security; and maintain the order of the socialist society.

ARTICLE 2. The Tasks of the Criminal Procedure Law of the People's Republic of China are to guarantee accurate and timely clarification of the facts of crimes, to apply the law correctly, to punish criminal elements, to safeguard innocent people from criminal prosecution, to educate citizens to observe the law voluntarily and to actively struggle against criminal conducts; so as to uphold the socialist legal system, to protect the citizens' personal, property, democratic and other rights and to guarantee the smooth progress of socialist construction.

PRC Criminal Procedure Law, supra note 302, arts. 1-2. Underscoring this collectivist emphasis, a recent government release cited not only its revised criminal laws, but also its "severe crackdown on crimes" as achievements on behalf of "the human rights of the people all over the country." Judicial Guarantees, supra note 314.

317. The existence of a presumption of innocence, for example, has been inferred from the new use of the term "defendant," instead of "offender," and from its statement that "[n]o-one shall be convicted without a verdict pronounced by a people's court according to the law." PRC Criminal Procedure Law, supra note 302, art. 12; see also Huang, supra note 294, at 181. The law omits a right to silence; in fact, it requires a defendant to submit to questioning during the investigative, prosecutorial, adjudicatory, and appellate stages of a criminal proceeding. See PRC Criminal Procedure Law, supra note 302, arts. 72, 91-96, 139, 155, 187.

318. PRC Criminal Procedure Law, supra note 302, art. 12. The Chinese Constitution similarly provides, "No citizen may be arrested except with the approval or by decision of a people's protectorate or by decision of a people's court, and arrests must be made by a public security organ." Min, supra note 291, at 220 (quoting XIANFA arts. 37, 40 (1982)) (observing that such phrasing "only points out the overall process without clarifying the due process concept"). Cf. MCKECHNIE, supra note 149 (quoting provision of the English Magna Carta 
does the law say that a trial must be fair or equitable. ${ }^{319}$ The new law thus mingles, but does not mesh, the Chinese and Western traditions.

That mingling has not satisfied Western human rights advocates. China's handling of political trials piques disapproval; ${ }^{320}$ recently, China thwarted efforts of political dissidents to secure counsel. ${ }^{321}$ The U.S. State Department recently proclaimed that enforcement of criminal law reforms is "poor," and stated that defendants frequently suffer "torture and mistreatment," "forced confessions, arbitrary arrest and detention, lengthy incommunicado detention, and denial of due process." ${ }^{332}$ Although the new Criminal Procedure Law forbids some of these practices, given the absence of explicit remedies $^{323}$ and of an independent judiciary, ${ }^{324}$ it remains to be seen whether the

from which due process is said to have derived).

319. News reports sometimes did use similar terms. See, e.g., Major Step to Maturity in China's Legal System, XINHUA NEws AGENCY, Mar. 14, 1997, available in LEXIS, Asiapc Library, Xinhua File, Item No. 0314146 [hereinafter Major Step] (stating that the law will "ensure judicial fairness"); Commentary, supra note 314 (referring to "fair trial"). Moreover, the revised criminal law enacted a year after the new PRC Criminal Procedure Law espoused the principle of "'equality for all before the law" - a principle that the head of the Chinese lawyers' association deemed of "'great significance to preventing abuse of power by judicial departments and safeguarding citizens' legitimate rights." Major Step, supra (quoting Zhang Binsheng, Vice-Chairman of the All-China Lawyers Association).

320. See, e.g., Erik Eckholm, Beijing Sends Potential Dissidents a Message: Don't, N.Y. TIMES, Dec. 25, 1998, at A3 (reporting that in face of criticism for its stepped-up prosecution of dissidents, China maintains that it is adhering to the ICCPR); Amnesty International, Annual Report 1998: China (visited Oct. 30, 1999) <http://www.amnesty.org/ailib/aireport/ar98/asa 17.htm> (stating that "[p]olitical trials continued to fall far short of international standards") [hereinafter China Report].

321. See Erik Eckholm, China to Try 2 Dissidents on Thursday but Denies Them Lawyers, N.Y. TIMES, Dec. 15, 1998, at A13; accord China Country Report, supra note 303, § 1(e) (stating that the new Criminal Procedure Law still falls short of international norms in part because it permits the government to deny suspects in "state secrets" cases access to lawyers).

322. China Country Report, supra note 303, intro. The U.S. State Department's report continued: "In many cases, particularly sensitive political cases, the judicial system denies criminal defendants basic legal safeguards and due process because authorities attach higher priority to maintaining public order and suppressing political opposition than to enforcing legal norms." Id.

323. Although the law bans coerced confessions, it prescribes no remedy for violation. See PRC Criminal Procedure Law, supra note 302, art. 43. An analysis by China's Supreme Court calls for exclusion of oral testimony based on coerced confessions, but would permit physical evidence obtained from leads such confessions generate. See Liling Yue, China, in CRIMINAL PROCEDURE: A WORLDWIDE STUDY, supra note 139, at 81, 85. No case has reported exclusion of evidence on this ground since enactment of the new criminal procedure law. See id.; see also Min, supra note 291 , at 248 (stating that the Chinese "police force is not well-regulated, and there are no effective restraints" on police misconduct); China Report, supra note 320 (claiming that China seldom sanctions those who extract confessions by torture).

324. See China Country Report, supra note 303, $\$ 1$ (e) (stating that China's judiciary "is subject to policy guidance from both the Government and the Communist Party"); Min, supra note 291, at 223-24, 248-49 (explaining that, in furtherance of democratic centralism, elected National People's Congress supervises judiciary, and calling for judicial review of governmental conduct); Huang, supra note 294, at 172, 181-82, 187-88. 
newly codified legal reforms will bring such practices to an end.

These examinations of the Islamic and Chinese systems reveal pulls both away from and toward a constitutional model of criminal procedure. Both the Islamic and Chinese systems entail an exaltation of the state, and law, as well as an emphasis on the needs of the collectivity over those of the individual. Westerners imbued in a tradition of inalienable rights find much that is unfamiliar or unacceptable in the ideals of Communist China and Islamic theocracies. Some Chinese and Muslims, meanwhile, resent pressure to adopt Western ideals without modification. These differences sometimes spawn open political hostility, and clearly work against convergence. But other factors work in favor. Despite differences about the nature of law and the state, at least in the area of criminal procedure, both the Islamic and Chinese systems contain provisions similar to those in the West. Domestic legal reform has arisen out of efforts to increase economic and political discourse with the outside world via overseas trade and membership in multinational organizations. Some Chinese and Islamic scholars have begun to espouse cosmopolitan views about human rights. These interchanges likewise may force change, or compromise, in the West. In sum, despite structural notes of discord, continued interaction may bring continued movement toward a kind of harmony.

\section{Erosion of State Status}

A state likely will voice loud objections to any component of convergence perceived to threaten its security or position in the world. The resistance of some states to the proposed International Criminal Court and the isolationist leanings of the United States exemplify this structural note of discord.

\section{a. Proposed International Criminal Court}

Although the statute for the Yugoslav Tribunal has been heralded as embodying generally accepted international principles, ${ }^{325}$ the Rome Statute of the proposed International Criminal Court is a political pact, an expression of the principles on which sovereign powers, aware that their nationals might one day face prosecution, could agree. ${ }^{326}$

325. See supra text accompanying note 214 .

326. Referring to compromises made in the definitions of war crimes-some of which cut back on existing perceptions of customary international law-a commentator wrote:

At this early stage it is impossible to predict what impact these new definitions will have. One important article states clearly that nothing in the statute will affect current or future international law. But the [Red Cross] is apprehensive that it may complicate its efforts to promote the Geneva Conventions and additional protocols.

Iain Guest, Beyond Rome-What Are the Prospects for the International Criminal Court?, ON THE RECORD 2, II 21 (Issue 23, July 27, 1998) <http://www.advocacynet.org/cgi-bin/ browse.pl?id=icc23.html > (referring to ICC Statute, supra note 219, art. 21). Nonetheless, the ICC Statute does require the court's actions to be "consistent with international recognized human rights." ICC Statute, supra note 219, art. 21(3). 
An example is France, a leading Western democracy and the home of Enlightenment philosophers, of the Déclaration des Droits de l'Homme, and of postrevolutionary criminal procedure reforms. ${ }^{327}$ Though it had favored revival of proposals for an ICC, for a time France sought the power to use the U.N. Security Council both to veto investigations and to decide whether to consent to prosecution of its nationals. ${ }^{328}$ At Rome, France successfully conditioned its endorsement of the ICC Statute on two concessions: first, installation of a Pre-Trial Chamber of judges to review the validity of investigations initiated by the prosecutor; and second, allowance of a seven-year period during which a member state could prevent the ICC from prosecuting its nationals for war crimes. ${ }^{329}$ Provoking French resistance was the army, which feared that its soldiers might be haled before the court. ${ }^{330}$ Worries about military strength struck at the heart of a state's sovereign being, and so posed a structural obstacle to any convergence that the ICC might foster. Its liberal tradition notwithstanding, France withheld support until a compromise alleviated its concerns.

Not all states agreed with the eventual compromise. Even as 120 states, including France, voted for the ICC Statute, 7 nay-sayers and 21 abstainers harbored misgivings. ${ }^{331}$ Some of the doubters were states that had signed the 1993 Bangkok Declaration limiting the international applicability of civil and political rights. ${ }^{332}$ China and Turkey protested the independence accorded the ICC prosecutor. ${ }^{333}$ China continued to demand that a state's national be subject to the court's jurisdiction only if the state has consented, ${ }^{334}$ and Turkey argued that the ICC Statute should have

327. See supra text accompanying notes 56-61, 150-56.

328. See Marc Epstein, Tribunal international: Le blocage français, L'EXPRESS, Dec. 2, 1998, at 84, 85; France Softens Opposition to World-Court Plan, GLOBE \& MAIL (Toronto), June 18, 1998, at A19.

329. See ICC Statute, supra note 219, arts. 15, 18, 19, 39, 53, 54, 56-61, 64, 72 (containing references to role of Pre-Trial Chamber); id. art. 124 (explaining opt-out provision); see also Dutch Disbelief at American "Defeatism": US Concern at Independent Prosecutor Irritate Allies, ON THE RECORD 3, ๆ 8 (Issue 4, June 18, 1998) <http://www.advocacynet.org/cgi-bin/ browse.pl?id=icc04.html $>$ (citing French support for "the idea of a pre trial chamber that would review proposals by the prosecution before any investigation goes forward"). Regarding the French position on war crimes, see Jude Webber, U.S. Accused of Derailing World Court, WASH. POST, July 15, 1998, at A25 (reporting attempt by France and the United States to allow states to opt out fully from responsibility for war crimes), and Jude Webber, US War Crimes Bid Backfires, S. CHINA MORNING POST, July 19, 1998, at 7 (stating that France had abandoned U.S. position and voted for treaty, which included the seven-year opt-out provision).

330. See Epstein, supra note 328, at 85; France Softens Opposition to World-Court Plan, supra note 328, at A19.

331. See Vitit Muntarbhorn, Overcoming Reticence on International Criminal Court, NATION, May 5, 1999, available in 1999 WL 15653415 (naming Iraq, Libya, China, Israel, Yemen, Qatar, and the United States as the seven opponents, and India, Turkey, and Singapore as among the abstainers).

332. See Bangkok Declaration, supra note 244; see also text accompanying notes 244,265 , 297 (discussing declaration).

333. See Muntarbhorn, supra note 331.

334. See id.; cf. ICC Statute, supra note 219, art. 12(2)(a) (permitting court to exercise jurisdiction if conduct occurs on territory of member state, even if accused is a national of a 
tempered war crimes prohibitions with "language stating that the court will not have anything to do with internal matters of states." ${ }^{335}$ Israel, site of a protracted land war, complained about the inclusion of a proscription against transferring population into occupied territory, ${ }^{336}$ while India, engaged in a nuclear testing campaign against Pakistan, objected to the omission of a ban on using weapons of mass destruction. ${ }^{337}$

Common to each complaint was "fear that the court would impinge strongly on national sovereignty. 3338 The states refused to accede to a treaty that required them to compromise but did not include provisions they deemed essential. As had France, some states worried that their nationals might improperly be subjected to ICC prosecution, perhaps for conduct the states did not consider criminal. But it seems unlikely that these states-some less developed, some with non-Westem traditions - will be able, like France, to secure concessions. They may be left with a choice of joining the ICC, at the expense of perceived sovereign interests, or facing isolation from a new world community.

\section{b. United States}

In contrast with many ICC opponents, the United States has a singular status as the world superpower. At counterpoint, however, is a persistent isolationism. Just as China stood out for its distinct cultural tradition, the United States represents an archetype of a state in which desire to retain its position may compel it to diverge from global trends it might otherwise follow.

Unlike China and Islamic states, the United States was founded on the philosophy that the individual has natural rights that the state must honor. The model of constitutional criminal procedure, which embodies this philosophy, reached a crescendo in a series of U.S. Supreme Court opinions articulating the doctrine of fundamental fairness. ${ }^{339}$ The dissemination of that model across the globe is due in no small part to "messianic" U.S. efforts. ${ }^{340}$ The United States has led the drafting and

nonmember state). India similarly disapproved of the role given to the U.N. Security Council to initiate or suspend prosecutions-in India's words, "'the power to block and the power to bind non-state parties." Muntarbhorn, supra note 331.

335. Muntarbhorn, supra note 331 (internal quotation omitted); See supra text accompanying note 266 (demonstrating such a complaint to be part of a cultural-relativist view of human rights).

336. See Muntarbhorn, supra note 331. Compare Panel Discussion, supra note 251, at 23334, 263 (remarks by Professor Malvina Halberstam criticizing inclusion of transferring population into occupied territory), with id. at 260-61 (remarks by Professor Leila Sadat Wexler) (supporting inclusion).

337. See Muntarbhorn, supra note 331 (quoting further Singapore's objections to omission of proscription against use of chemical and biological weapons). Similarly, Sri Lanka and Turkey complained because terrorism was not included among the crimes within the ICC's jurisdiction. See id.

338. Id. (quoting Israel as complaining that Rome Conference moved with undue haste to a final statute, forcing states to "by-pass very basic sovereign prerogatives to which we are entitled in drafting international conventions"').

339. See supra text accompanying notes 15-31.

340. Raymond, supra note 92 , at 1245 (further describing the U.S. view of its role in the 
negotiating of international instruments that afford accused individuals a panoply of rights. ${ }^{341}$ It has spoken out against human rights abuses by other states. ${ }^{342}$ It has played a key role not only in developing transnational law enforcement cooperation, but also in forming, funding, and staffing the ad hoc international criminal tribunals for the former Yugoslavia and Rwanda. ${ }^{343}$

Not unlike China and other states, however, the United States resists external pressure to conform its own criminal justice system to international standards. It too has bristled at those who have scrutinized U.S. practices-most recently, at a U.N. investigation into racial disparities in administration of the death penalty. ${ }^{344}$ And despite its liberal legal tradition and active participation in global crime-fighting, the United States ranks among the ICC treaty's few opponents. ${ }^{345}$

world as a "kind of imperialism, particularly rooted in the liberal intelligentsia, . . . not essentially economic, but rather cultural, idealistic, self-righteous, moral"). A recent poll indicates that these views also pervade the public at large. See Linda Greenhouse, Forty-Seven Percent in Poll View Legal System as Unfair to Poor and Minorities, N.Y. TIMES, Feb. 24, 1999, at A12 (quoting American Bar Association poll indicating that $80 \%$ of those polled agreed that "'in spite of its problems, the American justice system is still the best in the world"').

341. See, e.g., ANTONio CASSESE, INTERNATIONAL LAW IN A DIVIDED WORLD 289-90 (1986) (noting U.S. influence in transferring concepts contained in U.S. Bill of Rights into international law).

342. See, e.g., Remarks of Secretary of State Madeleine K. Albright, Press Briefing on the Release of the Country Reports on Human Rights Practices, 1999, Feb. 25, 2000 (visited Apr. 21,2000)<http://secretary.state.gov/www/statements/2000/000225.html> (emphasizing human rights violations in selected countries).

343. See Scharf, supra note 212, at 171-74 (discussing U.S. involvement in tribunal); supra text accompanying notes $\mathbf{8 0 - 8 1}$ (outlining U.S. role in law-enforcement cooperation).

344. The United States did allow a U.N. special rapporteur to investigate deaths in prisons and in police custody, whereas China refused to let him visit. Barbara Crossette, U.N. Monitor Investigates American Use of the Death Penalty, N.Y. TIMES, Sept. 30, 1997, at A9. Yet the rapporteur complained that he had been denied access to high-ranking U.S. officials like the President and the Attorney General. See id. His report described U.S. administration of the death penalty as arbitrary and racially discriminatory. Report of the Special Rapporteur on Extrajudicial, Summary or Arbitrary Executions, U.N. ESCOR, Hum. Rts. Comm., 54th Sess., Agenda Item 10, at 34, U.N. Doc. E/CN.4/1998/68/Add.3 (1998). Subsequently, U.S. legislators contended that such monitoring of U.S. practices constituted U.N. harassment. See Betsy Pisik, Human Rights Probes Irk U.S., WASH. TIMES, June 29, 1998, at A1; cf. Human Rights Watch, World Report 1999: United States (visited Apr. 14, 2000)<http://www.hrw.org/ hrw/worldreport99/usa/index.html> (stating that "[b]oth federal and state govemments" within the United States have "resisted applying to the U.S. the standards that, rightly, the U.S. applies elsewhere").

345. See supra text accompanying note 331 (tallying vote on ICC treaty and naming opposing states). Nevertheless, despite the outspoken opposition of the head of the Senate Foreign Relations Committee, the Clinton Administration continues to seek changes that would allow it to sign. See Gap Can Be Closed on ICC: Top US Negotiator, AGENCE FRANCE-PRESS Aug. 13, 1999, available in 1999 WL 2654340. The United States thus continues to participate in negotiations on unresolved issues: a definition for aggression, one of the five crimes within the ICC's jurisdiction; agreement on the elements comprising each crime; and creation of rules of evidence and procedure. See ICC Statute, supra note 219, arts. 5, 9, 51; David J. Scheffer, 
It is true that the U.S. Constitution places treaties on the same level as statutes, ${ }^{346}$ and that the U.S. Supreme Court has described international law as "part of our law."347 Yet U.S. ratifications of human rights treaties have come slowly, and burdened with reservations limiting the treaties' effect. ${ }^{348}$ Judge-made doctrines, like that requiring treaties to be either self-executing or supplemented by statutes, further circumscribe the application of international law in U.S. courts. ${ }^{349}$ Most U.S. courts do seem to agree that international law can give meaning to fundamental fairness and other constitutional principles. ${ }^{350}$ But while the Supreme Court at one time frequently drew support from global trends, ${ }^{351}$ today at least three U.S. Supreme Court Justices

Deterrence of War Crimes (visited Mar. 24, 2000) <http://www.state.gov/www/policy_ remarks/1999/990223_scheffer_hawaii.html>. For a recitation of the U.S. objections to the Rome Statute, see Is a U.N. International Criminal Court in the U.S. National Interest: Hearing Before the Subcomm. on International Operations of the Senate Comm. on Foreign Relations, 105th Cong. 10-15 (1998) (statement of Hon. David J. Scheffer, Ambassador-atLarge for War Crimes Issues, and head of the U.S. delegation to the Rome Conference).

346. See U.S. CONST. art. VI.

347. See The Paquete Habana, 175 U.S. 677, 700 (1900).

348. See, e.g., William A. Schabas, Invalid Reservations to the ICCPR: Is the United States Still a Party?, 21 BROOK. J. INT'L L. 277 (1995) (criticizing U.S. attachment of numerous reservations and declarations to its ratification of ICCPR, 16 years after the Covenant entered into force). U.S. ratification of the Convention on the Prevention and Punishment of the Crime of Genocide, art. II, Dec. 9, 1948, 78 U.N.T.S. 277, for example, did not come for a full 50 years. See U.N. Treaty Ratifications Website (visited Oct. 24, 1999)<http://www.un.org/Depts /Treaty/final/ts2/newfiles/part_boo/iv_boo/iv_1.html>; see also supra note 301 (relating delayed ratification of Convention Against Torture).

349. See RESTATEMENT, supra note 79, § 111 (explaining doctrine of non-self-executing treaties); accord Thomas M. Franck, Dr. Pangloss Meets the Grinch: A Pessimistic Comment on Harold Koh's Optimism, 35 Hous. L. REV. 684, 688 (1998) (commenting that such doctrines "have made Swiss cheese of the notion that international law is part of the law of the United States").

350. See, e.g., Thompson v. Oklahoma, 487 U.S. 815, 830-31 \& n.31 (1988) (affirming importance of international standards in determining if Eighth Amendment ban on cruel and unusual punishments violated); United States v. Davis, 905 F.2d 245, 248 (9th Cir. 1990) (allowing review of international law to determine touchstone question whether a practice is "fundamentally fair" within the meaning of the Due Process Clauses), cert. denied, 498 U.S. 1047 (1991); United States v. Thomas, 893 F.2d 1066, 1068-69 (9th Cir. 1990) (stressing that international law confers on an accused no independent rights). For discussion of this indirect use of international norms, see Mark Andrew Sherman, Indirect Incorporation of Human Rights Treaty Provisions in Criminal Cases in United States Courts, 3 ILSA J. INT'L \& COMP. L. 719 (1997).

351. For example, in Miranda v. Arizona, 384 U.S. 436, 444 (1966), the Court borrowed from discretionary rules devised in 1912 by English judges to hold that police should advise interrogees of their right to remain silent, of the consequences of speaking, and of their right to counsel. See also Culombe v. Connecticut, 367 U.S. 568, 595-98 (1961) (discussing these judges rules at length). In a series of other opinions, it looked to international law in deciding whether conduct violated the Eighth Amendment's ban on cruel and unusual punishment. See, e.g., Enmund v. Florida, 458 U.S. 782, 796-97 n.22 (1982); Coker v. Georgia, 433 U.S. 584, 596 n.10 (1977); Trop v. Dulles, 356 U.S. 86, 102 \& n.35 (1958). 
deem it inappropriate to consult international law in resolving constitutional questions. ${ }^{352}$

Given the crabbed role courts have ascribed to it, international law seldom sways U.S. decisions. Thus the Supreme Court held, without considering international law, that the Fourth Amendment does not protect aliens who have no substantial U.S. ties against unreasonable, U.S.-aided searches and seizures outside U.S. territory. ${ }^{353}$ The Court held that the Eighth Amendment permits execution of children as young as sixteen, notwithstanding contrary international authorities. ${ }^{354}$ Declining to consider the existence of an international right to silence and deferring to the government's predictions of harm to domestic law enforcement, the Court held that the SelfIncrimination Clause does not bar a U.S. court from forcing a witness to give testimony that might be used to convict him in a foreign court. ${ }^{355}$ The Court turned away bids to apply the international concept of degrading treatment, established by the European Court of Human Rights, in death-penalty cases. ${ }^{356}$ It ignored an

352. See Amann, supra note 4, at 1259-60 n.356 (analyzing current Justices' attitudes toward international law, and noting that Justice Scalia and Chief Justice Rehnquist "routinely reject" consideration of international law); infra note 356 (discussing Justice Thomas's position); cf. Vicki C. Jackson, Ambivalent Resistance and Comparative Constitutionalism: Opening up the Conversation on "Proportionality," Rights and Federalism, 1 U.PA.J.CoNsT. L. 583, 584-99 (1999) (describing U.S. judiciary's general resistance to comparative constitutional analysis, yet noting that on occasion even Justice Scalia and Chief Justice Rehnquist have expressed interest in the method).

353. See United States v. Verdugo-Urquidez, 494 U.S. 259 (1990). Whether the Bill of Rights applies overseas remains in question. See Bryan William Horn, Note, The Extraterritorial Application of the Fifth Amendment Protection Against Coerced SelfIncrimination, 2 DUKE J. COMP. \& INT'L L. 367 (1992) (outlining competing theories of minimal versus maximal protection).

354. See Stanford v. Kentucky, 492 U.S. 361, 389-90, 405 (1989) (Brennan, J., dissenting) (criticizing Court's judgment, and arguing that such executions are unconstitutional, in part because of international trends).

355. See United States v. Balsys, 524 U.S. 666 (1998). "In any event," the Court reasoned, "Balsys has made no claim under the Covenant, and its current enforceability in the courts of the signatories is an issue that is not before us." $I d$. at $695 \mathrm{n}$.16. The Court expressed reluctance to infringe on political branches' foreign-relations policies and justified its decision to avoid "serious consequences" to "domestic law enforcement." Id. at 698. Justice Stevens also agreed with the result on the ground that it would "not have any adverse impact on the fairness of American criminal trials." Id. at 770 (Stevens, J., concurring) (emphasis added). For a critique of this opinion, see generally Diane Marie Amann, International Decisions: United States v. Balsys, 92 AM. J. INT'L L. 759 (1998).

356. See Knight v. Florida, 120 S. Ct. 459 (1999); Lackey v. Texas, 514 U.S. 1045 (1995). In each case, a majority of the Court denied petitions for review in which condemned prisoners asserted that they had been wrongfully subjected to a complex of conditions known as the "death-row phenomenon." Lackey, 514 U.S. at 1045-46 (Stevens, J., joined by Breyer, J.) (mem.) (respecting denial of cert.); see Knight, 120 S. Ct. at 461-65 (Breyer, J., dissenting from denial of cert.). In 1989, the European Court of Human Rights had held that this phenomenon violated international standards. See Soering v. United Kingdom, 11 Eur. Ct. H.R. (ser. A) at 439; see supra text accompanying notes 113, 128 (discussing Soering and its influence in courts outside Europe). In Knight, Justice Thomas argued that only domestic precedents ought to matter; Justice Breyer disagreed. Compare Knight, 120 S. Ct. at 459 (Thomas, J., concurring 
International Court of Justice order and declined to consider whether an admitted violation of an alien defendant's treaty-based right to meet with consular officials precluded execution. ${ }^{357}$

Motivating such resistance to international influence is a sense of a unique global status. After World War II and throughout the Cold War, the United States saw itself as the leader in democratic ideals, a champion for "the free and fair American system of justice." ${ }^{358}$ Acknowledgment that others may have developed freer, fairer techniques would have been alien to that view. With the collapse of the Soviet Union, the United States has adjusted its role. No longer the free-world superpower, it sees itself as the lone remaining superpower, responsible for maintaining order within the world community, and thus deserving of special considerations. ${ }^{359}$ U.S. officials have used this image to justify the U.S. refusal, in spite of sharp criticism, to join a global ban on land mines or to establish a permanent, international criminal court. ${ }^{360} \mathrm{Such}$ refusals are fueled by an insularity that lingered even after the United States assumed a world role. The U.S. legal profession, for example, knows little about international law, and U.S. courts stand ready to defer to political-branch decisions about matters

in denial of cert.) with id. at 461-65 (Breyer, J., dissenting from denial of cert.).

357. See Breard v. Greene, 523 U.S. 371 (1998) (per curiam); Concerning the Vienna Convention on Consular Relations (Para. v. U.S.), 1998 I.C.J. 99 (Apr. 9). Amnesty International wrote of Breard: "No other US death penalty case in recent memory more tellingly reveals the glaring double standard which exists between the US human rights rhetoric abroad and its own domestic practices." Amnesty International Report 1998: United States of America (visited Oct. 24, 1999) <http://www.amnesty.org/ailib/aireport/ar98/amr51.htm>.

358. Raymond, supra note 92, at 1245. Such a view was articulated in 1948: "'It has been given to us, as the world's greatest democracy, a post of leadership in the all-important task of establishing our doctrines of civil liberty throughout the world as working principles by which the lives of free nations are to be governed."' 1 d. at $1245 \mathrm{n} .180$ (quoting Professor Robert E. Cushman).

359. Stating that the United States often prefers to act unilaterally if its self-interest does not coincide with those of other states, Professor Franck observed:

The first structural obstacle is that, for good or ill, we are the world's only remaining superpower .... Having to make our case for a course of action not only to Congress, but also to the various executive departments, agencies, and courts is time-consuming enough, without also having to argue the case before the United Nations Security Council, the General Assembly, the Organization of American States, the International Atomic Energy Agency, and, worst of all, the fifteen world jurists of the [International Court of Justice].

Franck, supra note 349, at 692.

360. See, e.g., Eric Schmitt, Why Clinton Plea on Pact Left Lott Unmoved, N.Y.TIMES, Oct. 15,1999 , at A11 (quoting Pennsylvania Sen. Arlen Specter's comment that some of the Comprehensive Test Ban Treaty's opponents "just want to have Fortress America"); Mark Fritz, Pentagon Seeks Funds for New Type of Land Mine Arms, L.A.TIMES, Feb. 20, 1999, at Al (reporting that Clinton administration, having refused to sign a landmine treaty in 1997 on the ground that it needed to protect its troops in Korea, now is seeking funds to develop a new type of land mine); Thomas W. Lippman, America Avoids the Stand: Why the U.S. Objects to a World Criminal Court, WASH. POST, July 26, 1998, at C1 (stating that during ICC negotiations in Rome, the United States "argued, in effect, that 'we're the ones who respond when the world dials 911 , and if you want us to keep responding, you should accommodate our views"'). 
touching on foreign affairs. ${ }^{361}$ But those branches are likely to repel efforts to conform their conduct to "foreign values,"362 and, in any event, to place domestic over international concerns. ${ }^{363}$

So long as it clings to this self-image-so long as it retains the power to do so-the United States, despite its fundamental rights tradition, is likely to continue to break the rhythm of global convergence in the name of national sovereignty.

\section{TOWARD HARMONY? PROSPECTS FOR A SHARED, CONSTITUTIONAL CRIMINAL PROCEDURE}

Changes swirl about the world of criminal justice. Once solely within individual states' control, crime-fighting has become a global venture. ${ }^{364}$ There is increased attention to global crime--to anonymous crimes like money laundering and to highprofile crimes like the Lockerbie bombing and the atrocities for which Milošević and Pinochet may one day stand trial. States band together against criminal activity that, more and more, knows no borders. Coinciding with these horizontal relationships is a vertical axis, exemplified by the establishment of tribunals to investigate, prosecute, and punish individuals for conduct that offends the international community. In keeping with transnational legal process theory, these repeated interactions, between states and among states and other entities, have prompted renewed scrutiny of the means used to fight crime. ${ }^{365}$

Such means often are measured against a keynote: a model of constitutional criminal procedure. ${ }^{365}$ The model features, to use Professor Craig M. Bradley's apt phrase, a "quiver of rights" - rights to counsel, to remain silent, to be free from unreasonable searches and seizure-with which an accused person may defend

361. On this point, Professor Franck has written:

[T]o the extent that our judges have "internalized" anything about the world external to the United States, it is that "[t]he conduct of the foreign relations of our Government is committed by the Constitution to the Executive and Legislative-'the political'-Departments of the Government, and the propriety of what may be done in the exercise of this political power is not subject to judicial inquiry or decision."

Franck, supra note 349, at 695 (alteration in original) (quoting Oetjen v. Central Leather Co., 246 U.S. 297, 302 (1918); cf. supra text accompanying note 355 (remarking on Court's expressed deference to political branches in holding that Self-Incrimination Clause has no extraterritorial effect).

362. Jordan J. Paust, Customary International Law in the United States: Clean and Dirty Laundry, 40 GERMAN Y.B. INT'L L. 78, 105 (1998) ("The fear of foreign values can also be identified as a factor contributing to current stress on the efficacy of customary international law within the United States."); see id. at 103-06 (discussing perception of U.S. political elites that enforcement of such law would endanger their political power).

363. See Franck, supra note 349, at 697-98 (concluding that "[i]n the American instance, at least, the democratic structure appears to make the legal culture especially impenetrable").

364. See supra text accompanying notes 75-89, 201-32.

365. See supra text accompanying notes $40-42$ (positing that repeated horizontal and vertical interactions with other states and international entities is likely to lead a state to obey international law).

366. See supra text accompanying notes 15-31, 150-61. 
against the state's prosecutorial arsenal. ${ }^{367}$ The model has origins in Europe, in the works of medieval natural law theorists and Enlightenment philosophers, and in the revolutionary unrest of the late eighteenth century. It matured in the United States. There a Bill of Rights first expressly prescribed how the government may administer criminal justice. These prescriptions are not, however, just techniques. As the U.S. Supreme Court reiterated, they enunciate rules fundamental to the constitutional admonition that no one may lose life, liberty, or property without due process of law. Governmental interpretations of the principles of equality and fundamental fairness thus have resulted in rules of criminal procedure with a strong substantive component. Though they need not be found in an explicit passage of a constitution, such rules comprise a "constitutional" criminal procedure because they are constitutive of civil society based on the fundamental rights tradition.

Writings in the United States sometimes suggest that this model of constitutional criminal procedure is unique. That is far from the case. Even as the U.S. Supreme Court opinions in the first half of the twentieth century shaped the model, there were global movements toward convergence around such a model ${ }^{368}$ Notes of concordance had sounded in Europe in the early 1800 s, when post-revolutionary reforms introduced aspects of the accusatorial criminal procedure method, used in common law systems, into the inquisitorial method that had prevailed on the European continent. They sounded again in the mid-twentieth century, when Allied efforts to bring to trial individuals accused of World War II atrocities produced a code of criminal procedure that further blended the two methods. In the postwar era a new community of values, based on the view that the international law must respect the rights of the individual as well as the interests of the state, emerged. ${ }^{369}$ On a horizontal plane, states joined human rights treaties that repeated many of the fairtrial guarantees contained in the U.S. Bill of Rights. States that had embraced human rights norms conditioned other states' receipt of benefits such as foreign aid on adoption of those norms. On a vertical dimension, just as civil liberties groups aided development of a U.S. constitutional criminal procedure, nongovernmental groups and individuals used public criticism, lobbying and litigation, and grass-roots activism to press states and international organizations to honor rights of the accused.

Evolution of a global criminal procedure is perhaps most advanced in two supranational settings: in Europe, the scene of intense regional integration, and in the resurgence of international criminal tribunals. Opinions of the European Court of Human Rights have required states to comply with the European Human Rights Convention, which contains many of the rights emblematic of constitutional criminal procedure. Efforts are under way within the quasi-federal European Union to distill from the accusatorial and inquisitorial methods a single body of procedure for adjudicating financial crimes. Meanwhile, the ad hoc Rwanda and Yugoslav tribunals employ hybrid procedural codes, expressly founded on respect for the rights of the individual, to bring international criminals to justice. The proposed permanent International Criminal Court may follow that lead. Present in both examples are the

367. See Bradley, Convergence, supra note 1, at 473.

368. See supra text accompanying notes 33-232.

369. Cf. supra text accompanying note 39 (mentioning "communitarian Grotian" theory that stresses development of common values within international society). 
kind of political and economic interactions that should lead, according to transnational legal process theory, to compliance with international legal norms. But reference to these interactions alone pretermits a critical element of harmony, one that transnational legal process theory has been criticized for downplaying. ${ }^{370}$

That element, adherence to a shared liberal, democratic tradition, has appeared at watershed moments of convergence. Animating the reforms just after the French Revolution was the Déclaration des Droits de l'Homme, with its proclamations of inalienable individual rights to liberty and equality. The charters establishing the postWorld War II trials at Nümberg and Tokyo promised defendants a "fair trial." Subsequent international documents enunciated the rise of individual rights as a proper subject of international law. In both European integration and the development of the international tribunals, the dominance of the fundamental rights tradition has won express approval. It seems clear, therefore, that criminal procedure will move most swiftly and smoothly if sufficient political or economic discourse and a shared legal tradition are present.

If one of these elements is impaired, discordant notes may be heard. Some appear temporal, able to alter with time. ${ }^{371}$ For example, rights central to a constitutional criminal procedure model may be threatened by increased surveillance to combat global crime. But a change in attitude-a sense that the crime rate has steadied, or that police work ought not to violate individual rights-could repair the harm to the fundamental rights tradition. Similarly, infusion of resources from the international community could end divergence caused by an inadequate interaction; that is, by a dearth of money or institutions to implement international norms. Finally, voices raised against the compromises inherent in establishment of hybrid organs could spur innovations that protect human rights even more than the methods from which those hybrids derived.

Other impediments to harmony do not admit easy solutions. Such structural notes of discord arise when an innovation intrudes on a state's individual sovereignty; for example, by requiring a state to deviate from entrenched cultural tradition. ${ }^{372}$ Although international conventions profess to enshrine universally accepted human rights, some find in those articulations too strong a Western influence. Examples may be found in the Islamic states and in China, both of which have legal traditions far different from that of the West. The emphasis on the state and collectivity in the former clashes with the emphasis on the individual in the latter. This basic difference, sometimes coupled with lingering post-colonial resentments, provokes recriminations about each group's human rights records. At times overt political disputes break out.

370. See Koh, supra note 35, at 674-77 (maintaining that other elements of repeated transnational interaction will bring about obedience to international norms, even in "illiberal" states); see also supra text accompanying note 38 (describing "liberal Kantian" theory, which stresses importance of commitment to fairness and related principles). But see Robert O. Keohane, When Does International Law Come Home?, 35 Hous. L. REv. 699, 709-12 (1998) (criticizing Professor Koh for minimizing importance of state's legal structure, and listing characteristics of liberal states that increase likelihood of state's obedience to international norms).

371. See supra text accompanying notes 238-62.

372. See supra text accompanying notes 263-324. 
In such a climate, convergence toward a constitutional criminal procedure model seems unlikely.

And yet there is such movement. More secular Muslim states have promised to conform aspects of their criminal justice systems to prevailing international norms. Some scholars contend that a desire for individual rights is not unique to the West, and some Muslim scholars push for integration of international human rights norms into Islamic law. In the area of criminal procedure, there are significant similarities between the Western and the Islamic methods. Although these factors suggest common ground on which convergence might occur, diversity among Islamic states and political volatility make predictions about convergence seem rash.

A more focused inquiry is possible in China, which has sought greater status within in the international community. Change is most salient in the economic arena, where China has cultivated a domestic market economy, secured overseas trading partners, and applied to join the World Trade Organization. These interactions seem already to have prompted some convergence: in the late 1990s China endorsed a number of rights of the accused by passing a new Criminal Procedure Law and by signing the ICCPR. Transnational legal process theory would seem to predict that, at least in the long term, China will join the international trend toward convergence in criminal procedure. $^{373}$

Still, formidable structural obstacles remain. The constitutional criminal procedure model depends on a separation of powers, in particular on an independent judiciary, which does not exist in China. Not surprisingly, Chinese reports on the new Criminal Procedure Law described the rights of the accused not as "inalienable," but rather as "legitimate," a word implying privilege rather than entitlement. The description conforms to China's centuries-old tradition of valuing the needs of the collectivity over those of the individual, and demonstrates the limited applicability of a Westernstyle, rights-based discourse to contemporary Chinese culture. It thus would be foolhardy to expect that the Criminal Procedure Law's articulation of, say, a right to counsel will produce the kind of defense now considered the norm in Western legal culture. ${ }^{374}$ In sum, repeated interaction between China and the West will set off a web of horizontal and vertical relationships and thus foster greater attention to and adaptation of Western legal norms. But the day seems distant when such relationships will transform China's national identity enough to embrace fully the fundamental rights tradition on which the constitutional criminal procedure model is based.

Conversely, the presence of both a fundamental rights tradition and repeated interactions with the world community does not guarantee convergence. If a state believes that a certain innovation will threaten its security or otherwise undercut its

373. See Koh, supra note 35, at 675-76 (stating that "over time," China's interactions with the outside world will prompt pressures, from within and without, to adopt international norms); see also supra text accompanying note 313.

374. Cf. Christopher Harding et al., Conclusion-Europeanization and Convergence: The Lessons of Comparative Study, in CRIMINAL JUSTICE IN EUROPE: A COMPARATIVE STUDY, supra note 46 , at 379,386 (warning that, as a result of the "deep-rooted nature of certain national concepts, procedures, and institutions, there may be dangers in transposing the approach of other systems without taking into account the depth of national tradition and outlook"); Wladimiroff, supra note 257, at 1449 ("The problem is that the concept of a fair trial should and can only be understood in the context of the system in which it functions."). 
position within the international community, the state will resist. ${ }^{375}$ Thus France, a center of diplomacy and a birthplace of the fundamental rights tradition, balked at the Statute of the proposed International Criminal Court until it received assurances that its nationals would not be prosecuted unduly. The United States, site of refinement of a constitutional criminal procedure model, evinces significant isolationist leanings. Along with a handful of smaller states, it continues to oppose the ICC. ${ }^{376}$ Its rejections of bids to obey international norms that offer the individual greater protection than does U.S. law attract criticism. Such conflicts are likely to persist, given new assaults on the constitutional criminal procedure model within the United States. ${ }^{377}$ Thus the United States stands as an archetypical example of how, despite many elements of harmony, perceived threats to national sovereignty can strike discord in the trend toward convergence in criminal procedure.

375. See supra text accompanying notes 325-63.

376. For the other states, the cost of opposition may be too high, in the form of fears that their nationals brought before the court would suffer because of their nonparticipation, or of fears that the international community might withhold other benefits from them. Eventually these states might prefer acquiescing in an imperfect ICC to suffering some harm to selfinterest. $C f$. Keohane, supra note 370 , at 704 (positing that a state may adhere to rules rather than face "exclusion from the club," even as "participants bask in the benefits of coordination"); Koh, supra note 35, at 634 (discussing theories of "realists," who maintain that a state complies when it believes it has no choice, and "rationalists," who contend that a state obeys if it decides, even if grudgingly, that compliance is in its best interest). It seems less likely that such considerations would goad the United States into joining the ICC, given its chronic isolationism and its unique superpower status.

377. See, e.g., United States v. Dickerson, 166 F.3d 667 (4th Cir. 1999), cert. granted, 120 S.Ct. 578 (1999) (holding that a 1968 federal statute that prescribes "voluntariness" as the test for admitting confessions supersedes the more stringent requirements of the landmark constitutional criminal procedure doctrine enunciated in Miranda v. Arizona, 384 U.S. 436 (1966)); Kahan \& Meares, supra note 16, at 1153 (arguing that some aspects of the model "have outlived their utility"); Raymond, supra note 92, at 1234 ("The constitutional protections were motivated by a profound suspicion of government authority that the public may no longer feel."); Steiker, supra note 31, at 2469 (stating that the U.S. Supreme Court has retained that part of the model "governing investigative techniques," but "has revolutionized the consequences of deeming conduct unconstitutional"). 
HeinOnline -- 75 Ind. L.J. 8742000 